\title{
Architecture's Role in Nation-Building: The Palestinian National Library,
}

by

\author{
Anthony O. Sproul \\ B.A.S. Carleton University 2003
}

A thesis submitted to the graduate faculty at the

School of Architecture, Carleton University,

in partial fulfilment of the requirements

for the degree of
Master of Architecture

(M.ARCH)

Professional

Anthony O. Sproul (C) 2005 
Archives Canada

Published Heritage

Branch

395 Wellington Street

Ottawa ON K1A ON4

Canada
Archives Canada

Direction du

Patrimoine de l'édition

395 , rue Wellington

Ottawa ON K1A ON4

Canada
NOTICE:

The author has granted a nonexclusive license allowing Library and Archives Canada to reproduce, publish, archive, preserve, conserve, communicate to the public by telecommunication or on the Internet, loan, distribute and sell theses worldwide, for commercial or noncommercial purposes, in microform, paper, electronic and/or any other formats.

The author retains copyright ownership and moral rights in this thesis. Neither the thesis nor substantial extracts from it may be printed or otherwise reproduced without the author's permission.
AVIS:

L'auteur a accordé une licence non exclusive permettant à la Bibliothèque et Archives Canada de reproduire, publier, archiver, sauvegarder, conserver, transmettre au public par télécommunication ou par l'Internet, prêter, distribuer et vendre des thèses partout dans le monde, à des fins commerciales ou autres, sur support microforme, papier, électronique et/ou autres formats.

L'auteur conserve la propriété du droit d'auteur et des droits moraux qui protège cette thèse. $\mathrm{Ni}$ la thèse ni des extraits substantiels de celle-ci ne doivent être imprimés ou autrement reproduits sans son autorisation.
In compliance with the Canadian Privacy Act some supporting forms may have been removed from this thesis.

While these forms may be included in the document page count, their removal does not represent any loss of content from the thesis.
Conformément à la loi canadienne sur la protection de la vie privée, quelques formulaires secondaires ont été enlevés de cette thèse.

Bien que ces formulaires aient inclus dans la pagination, il n'y aura aucun contenu manquant.

\section{Canadä}




\begin{abstract}
Social, cultural and political agendas often play a key role in the conception of architecture, as does the regional climate, regional history and surrounding context. The carceral image of Palestine created by the architectural narrative of place plays an important role in shaping the image and political predisposition towards Palestinians.

The Palestinian National Library is a series of stories that expose some aspects of Palestinian cultural identity. This is accomplished through the relationship between the viewer, their perception and interpretation, and the architectural intentions explained through the conceptual embodiment of the project. The architecture can be read through the relationship between human interaction and metaphoric interpretation as shaped by our understanding of architecture and subsequently by our understanding of place. Thus, the library serves to forge a new identity for the Palestinian people, an identity that recognizes their past while offering a living tableau on which to write their future.
\end{abstract}




\section{Acknowledgements}

I would like to thank my thesis advisor Stephen Fai for his support and direction. To Mark Macguigan who helped me in the shop learning to operate the equipment necessary to accomplish my goals. To my colleagues, Roberto Campos for his daily constructive criticism and James Hayes for his help simulating light angles through computer modelling. To Alison Zinni in Barcelona who spent many hours editing my thesis. To my parents Kent H. Sproul and Sarah Dahabieh, my brother Christopher Sproul and Tiana-Karissa Beauchamp for their patience, and support. 


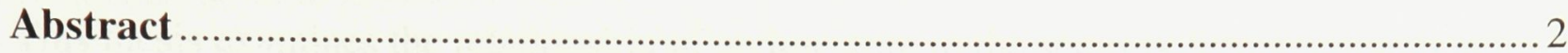

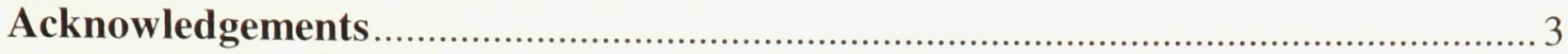

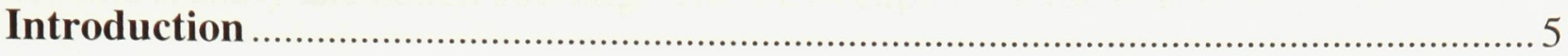

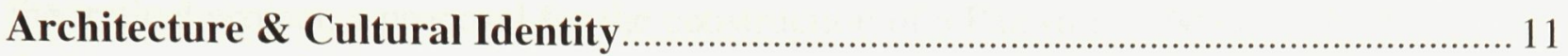

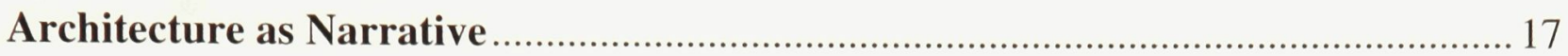

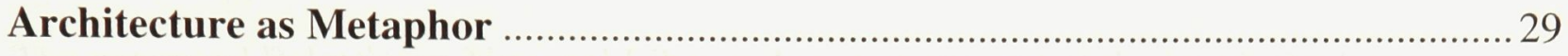

Archaeological Myth and Architectural Metaphor ......................................... 32

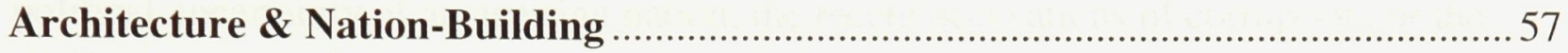

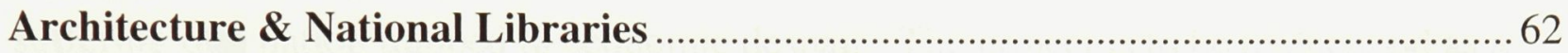

The Alexandriana Library Past and Present .............................................. 68

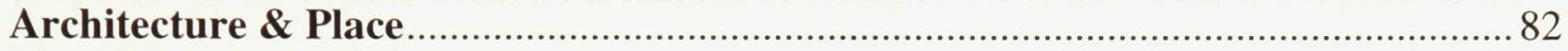

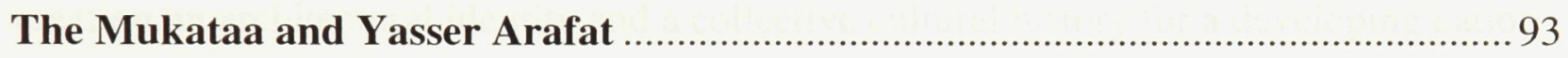

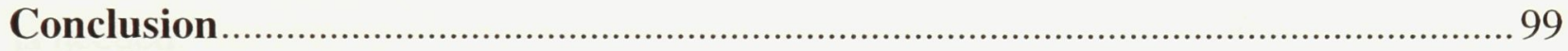

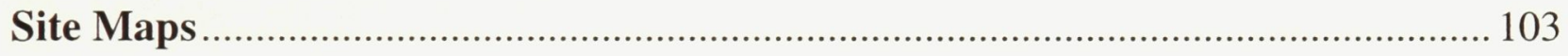

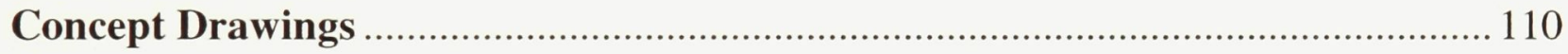

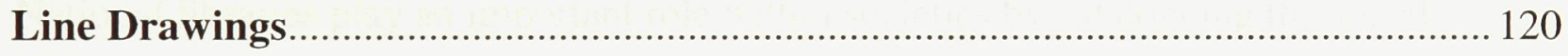

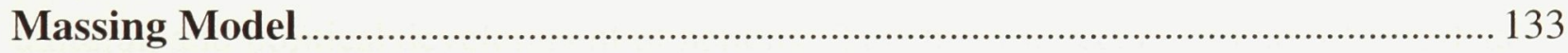

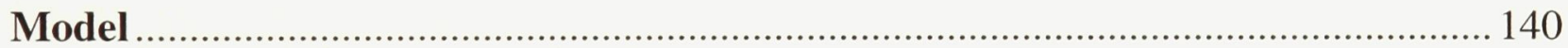

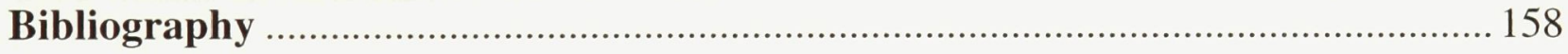




\section{Introduction}

This thesis examines the relationship of architecture to the socio-political concepts of cultural identity and nation building. The thesis explores these relationships through a theoretical project, a proposal for the construction of a Palestinian National Library.

The proposed Palestinian National Library does not attempt to deal with the larger political uncertainty of an aspiring nation, the recent accusations of corruption, or the suffering of a nation trapped in economic despair. The project is to be understood as a proposal for the future, when a Palestinian sovereign state is declared, and a process for creating an architectural identity and a collective cultural history for a developing nation is needed.

National libraries play an important role within societies by cataloguing the social, cultural, and political development of nations. This historic record provides basic data used within an information society to create knowledge. That knowledge, once appropriated, creates shared histories and shared identities. It is this shared history and shared identity that binds a society together and provides the basis for political power.

The Mukataa is the site chosen for the development of the Palestinian National Library. Social, cultural, and political agendas often play a key role in the conception of architecture, as does the regional climate, regional history, and surrounding context. These factors shape architecture to varying degrees and can be found present in all buildings to some extent. In modern day Palestine, the Mukataa is the headquarters of 
the Palestinian leadership. Due to fifty years of military turmoil, a large portion of the complex has been destroyed. This site, the current command center of the Palestinian Authority, was the size of several city blocks in what used to be a prosperous neighbourhood in Ramallah. The buildings were the site of an army base in support of the British occupation in the first half of the $20^{\text {th }}$ century, then became a Jordanian administrative center until 1967 when Israel occupied the area during the six day war. Following the Oslo accord, the Mukataa became the headquarters for the Palestinian Authority. From the earliest development of the site, the various building programs have always contained a prison. This carceral image has played an important role in shaping the image and political predisposition of Palestinians.

The Mukataa provides an architectural opportunity - the opportunity to influence the cultural image of Palestinians through the creation of a much-needed national library. Through its various historical occupants, the site embodies the building programs, that historicise the architectural narrative of contemporary Palestinian history. Today, the Mukataa can be seen to represent the last remaining authority of Palestinian sovereignty seeking to become a recognized part of the international global community.

In the first section of the thesis, Architecture and Culture, I examine the concept of identity and, in particular, cultural identity. I begin by asking the very personal question, Am I a Palestinian? This is followed by a more formal review of the notion of identity, a review that relies heavily on the works of Edward Said and Paul Ricoeur. 
In the second section of the thesis, Architecture as Narrative, I introduce the idea of narrative, reviewing the works of a number of authors. I argue that it is through narrative or story telling that identity is created. Architecture provides the images with which to write this narrative.

In the third section, Architecture as Metaphor, I introduce the third leg of the conceptual stool, metaphor. The metaphor allows us to transcend the constraints of language, forging new connections to old messages.

Next, in Archaeological Myth and Architectural Metaphor, I look at how these concepts all come together by reviewing the case of the Western Wall at Temple Mount. The Western Wall has played, and continues to play, an important role in the development of Israeli cultural identity. It clearly demonstrates the use of narrative and metaphor in the development of identity and the furthering of national aspirations.

In the next section, Architecture and Nation-Building, I introduce the notion of nationbuilding as an important notion within the context of this project. Nation-building is often associated with assumptions about developing third-world societies and is linked to the notion of de-colonization. Over the past decade, it has been applied to societies such as Palestine, Haiti, Somalia, Bosnia, Kosovo, most of Africa and, more recently, to Afghanistan and Iraq. Nation-building is associated with government authority and political power, a geopolitical reconciliation process creating a shared identity through the development of social, cultural, and political infrastructure. "Nation-building 
occurred successfully on a large scale in earlier generations by working against and breaking away from superpowers and other external nations, rather than under their guidance or tutelage."1

In Architecture and National Libraries, I provide additional context. National libraries play a particular role within societies. In order to be considered "a national library", the library must meet specific standards and be capable of undertaking prescribed tasks. In this section, I provide some of this background.

Moving from the more general to the more specific, in The Alexandriana Library Past and Present, I look at how these ideas are applied in the context of the building of an actual library. The Alexandriana is arguably the first library ever built. Long since destroyed, and the actual designs lost in antiquity, the new Alexandriana was recently completed and officially opened on October 16, 2002.

Narrowing-in on the actual project in Architecture and Place, I examine the role of place within an architectural project. In particular, I look at Palestine. This thesis questions the relationship between architecture and representations of place. It argues that architecture can shape the narrative of a nation. Architecture plays an important role in shaping the image of a nation through the creation of stories that become representations of identity, thereby influencing the cultural assumptions of place. In the case of Palestine, the

1 Etzioni, A. A Self-Restrained Approach to Nation-Building by Foreign Powers. Blackwell Publishing: International Affairs, Vol. 80, no. 1 1-17. January 2004 
architectural stories marginalise the nation and the people. The library seeks to offer a new interpretation of the relationship between the nation, the people, and the land.

In The Mukataa and Yasser Arafat, I narrow-in on the actual site of the proposed library, the Mukataa. The narrative begins with the current site - a series of bombed buildings that represent the last authority of the Palestinian government. The buildings, sculpted by the various occupations during the British, Jordanian and Israeli rule, were used to imprison generations of Palestinians under the rule of successive oppressors. Today, these buildings are represented as the Palestinian government.

Finally, in the Conclusion, I outline the project, a Palestinian National Library that will serve to forge a new identity for the Palestinian people, an identity that recognizes their past while offering a living tableau on which to write their future.

The weapons of the past are melted down and from them is forged a new weapon. Rising from the darkness, the material, once crafted for violence, takes new shape. The identity of a nation is cast from its defeats. Its defences are silent. It defends no more. Time ceases to destroy, but remembers.

A wall rises from the darkness. The wall embodies the past and future. The steel is transformed by the many voices of a people rising into the light. The wall transcends time. 
Through the courtyard the Diaspora return throughout the ages to reflect upon their shared identity and shared perspective. They ponder the last of the olive trees uprooted from their native land. They observe the sun reflecting upon the water beyond the wall. They witness and scrutinize the authority of governance. They learn of the teachings their ancestors left behind. They write down that they too have been to Palestine. 


\section{Architecture \& Cultural Identity}

Architecture is a form of cultural identity or collective history. The notion of place and culture cannot be understood through architecture alone, but architecture remains one of the transcendental texts by which a society's culture can be interpreted.

Neil Leach in his article Belonging states: "Cultural identity, therefore, emerges as a complex field of operations that engages with but is not defined by - cultural artefacts such as architecture." 2 According to Leach, architecture cannot define culture but rather creates an object within which culture can be examined and discussed. Comprehending the reasons by which the architectural artefact was created and the iconography within its context contributes to understanding and, therefore, to its role as a cultural symbol.

What is identity? Am I a Palestinian? As I sat in the Palestinian Ambassador to Canada's Ottawa living room in 2003, discussing a previous project for the development of a Palestinian embassy in Ottawa, this question was answered for me. Dr. Baker Abdel Munem a well-educated man with Doctorates in Engineering, Economics, and Political Science, told me that any person whose parent was born in Palestine is eligible to get a Palestinian passport. The idea was novel. As my mother was born in Haifa, I could obtain a Palestinian passport. I could be a Palestinian.

The issue of whether I am a Palestinian, like so many other questions of identity, is more complicated than is perhaps suggested merely by my mother's birthplace or eligibility for

2 Leach, Neil. Belonging. AA Files 49. 76 
a Palestinian passport. In reality, my teta, or grandmother, was born in Palestine, as was her mother before her. However, my jido, or grandfather, was born in Bludan, a small mountain village in Syria, and moved to Palestine as an adult looking for work.

My mother, born in Haifa, during the period when Palestine was a British protectorate, only lived in Palestine for one month of her life. Zionist insurgents captured Haifa on April 23, 1948. This led to tens of thousands of Palestinian Arabs to flee their homes. My grandparents went first to Bludan, waiting to return to their home in Haifa. After two years they joined other displaced relatives in Beirut, Lebanon, again waiting to return home. As their financial resources depleted, my jido left his family and travelled to Eden, Yemen, where he worked as a foreman constructing base camps for oil exploration. He returned to Beirut and started a small business making furniture. Subsequently, my mom's family immigrated to Canada just before the Lebanese civil war began.

My mother met my father, a $5^{\text {th }}$ generation Canadian on his mother's side, and a second generation Canadian on his father's side. My grandfather on my father's side was born in Egypt in 1914 during a period when Egypt was a British colony, just prior to the First World War. He never knew his father who was killed in an automobile accident in France two years later. My grandfather grew to adolescence in England, moving with his mother and brother to Canada, a new country where the dreams of a new life could flourish. 
As seen by my family lineage, I represent the cross-fertilized nature of cosmopolitan life, being of many identities, originating from a variety of cultures. As demonstrated by my own life, classifying one's national identity is often much more complex than where you live or even from where your parents or grandparents originate. However, where you live and your identity with respect to your lineage does tend to shape your culture, or, as Said would argue, your exposure to certain cultural narratives that shape your beliefs.

Said states in Orientalism the production of knowledge is not objective, but is subjugated by one's geographical cultural heritage. No objective production of knowledge is purely scientific, as authorship is territorially subjective. Authorship implies a subjective humanity imbued with territorial predispositions. ${ }^{3}$

Orientalism is defined as:

"Not a mere political subject matter or field that is reflected passively by culture, scholarship, or institutions; nor is it a large and diffuse collection of texts about the Orient; nor is it representative and expressive of some nefarious 'Western' imperialist plot to hold down the 'Oriental' world. It is rather a distribution of geopolitical awareness into aesthetic, scholarly, economic, sociological, historical, and philological texts; it is an elaboration not only of a basic geographical distinction (the world is made up of two unequal halves, Orient and Occident) but also of a whole series of 'interests' which, by such means as scholarly discovery,

3 Said, Edward. Orientalism. New York: Vintage Books, 1979. 11 
philological reconstruction, psychological analysis, landscape and sociological description, it not only creates intention to understand, in some cases to control, manipulate, even to incorporate, what is a manifestly different (or alternative and novel) world; it is, above all, a discourse that is by no means indirect, corresponding relationship with political power in the raw, but rather is produced and exists in an uneven exchange with various kinds of power, shaped to a degree by the exchange with power political (as with a colonial or imperial establishment), power intellectual (as with reigning sciences like comparative linguistics or anatomy, or any of the modern policy sciences), power cultural (as with orthodoxies and canons of taste, texts, values), power moral (as with ideas about what 'we' do and what 'they' cannot do or understand as 'we' do)."4

Edward Said's critique of the West in relation to history, culture, and political perceptions, demonstrates how the West developed, through the representation of the 'other'. These cultural predispositions continue to dominate and misrepresent truth. As demonstrated by Said's book Orientalism, a given text builds upon the assumptions of previous works and therefore reasserts assumptions and strengthens the fabric of received knowledge.

"Foucault believes that in general the individual text or author counts for very little; empirically, in the case of Orientalism (and perhaps nowhere else) I find this not to be so. Accordingly my analyses employ close textual readings whose

4 Said, Edward. Orientalism. New York: Vintage Books, 1979. 12 
goal is to reveal the dialectic between individual text or writer and the complex collective formation to which his work is a contribution."

Bernard P. Dauenhauer examines the phenomenon of political identity in relation to the work of Paul Ricoeur. Political identity forces the individual to accept a set of assumptions that are not of his/her own creation. Political identity divides humanity into an included "us" and an excluded "them". Political identity homogenises, in a society, what would otherwise exist as a set of autonomous identities. "Narrative identity intervenes in the conceptual constitution of personal identity as a "mediator between the pole of character, where idem and ipse tend to coincide, and the pole of self-maintenance, where selfhood frees itself from sameness"'. 6 (see footnote for idem-identity and ipseidentity $)^{7}$ Through narrative we understand ourselves both as individuals within a society and as one person within a common humanity.

Political identity, Dauenhauer argues, seeks to negate the ipse identity that differentiates our character and is the basis of individuality. One must give up a certain amount of their own individuality in order for a political society to create the illusion of a homogeneous identity. Like personal identity, political identity is created through the use of narratives. Political narratives seek to claim exclusive right to the territory they speak of as their homeland. Though no actual political society can establish an incontestable

\footnotetext{
5 Said, Edward. Orientalism. New York: Vintage Books, 1979. 24

6 Dauenhauer, Bernard. "Ricoeur and Political Identity" Paul Ricoeur and Narrative: Context and Contestation. Calgary: University of Calgary, 1997. 131

7 Ricoeur uses Heidegger's two-fold definition of personal identity, where personal identity is split between (idem-identity) which belongs to every entity, human or otherwise, and the identity of self (ipse-identity) which only human beings can have.
} 
clear title to its land, political narratives try to make claims for which there is no conclusive evidence. "Hence they are always, in Ricoeur's technical sense, either ideological or utopian or both.",

Political identity, unlike personal identity, outlives its individual members. The construction of narrative, being set within a timeframe, has a beginning, a middle, and an end. A political narrative does not differ from this formula but is not regulated within the life expectancy of a person.

"From the standpoint of political identity, the death of a member has an importantly different meaning. It marks the line for passing a baton to a successor rather than the line at the end of the race. A person's political identity consists in membership, in the joint pursuit of a common project. From its inception, this project is meant to outlast the lives of any of its individual members.",

Just as death within a political narrative does not signal the end of the story, birth is not the beginning. One is born into a cultural narrative and finds their place within a story that has both a past and a future. As such, "each society must face the judgment of subsequent generations, both of its own members and of foreigners.",

8 Dauenhauer, Bernard. "Ricoeur and Political Identity" Paul Ricoeur and Narrative: Context and Contestation. Calgary: University of Calgary, 1997. 133

9 Dauenhauer, Bernard. "Ricoeur and Political Identity" Paul Ricoeur and Narrative: Context and Contestation. Calgary: University of Calgary, 1997. 133

10 Dauenhauer, Bernard. "Ricoeur and Political Identity" Paul Ricoeur and Narrative: Context and Contestation. Calgary: University of Calgary, 1997. 136 


\section{Architecture as Narrative}

The notion of interpretation, examined by Umberto Eco in his discussion of truth, advocates that truth lies beyond the vernacular visual reading of place. Within contemporary interpretation one can only contemplate meaning as an abstracted illusion of truth. Such truth is limited to our emotional rendering and can only be read as allegorical interpretations. Meaning through interpretation cannot carry transcendental truth, but can create a subjective discourse through the superimposition of new meaning. "Thus truth becomes identified with what is not said or what is said or what is said obscurely and must be understood beyond or beneath the surface of a text."11

This is perhaps best exemplified in the works of John Hejduk, specifically his wall houses of the early 1970's. Here, an object such as a wall, is used as the primary object of design. In Hejduk's work, the boundaries of interpretation are stretched and the object's function and meaning are brought into question, thereby revealing a truth beyond the surface of the artefact.

The division between those who are empowered with the ability to represent and those who are not can be found in a variety of disciplines. I will argue more precisely that architectural narrative has been a contributing factor in the misrepresentation and marginalization of Palestine and Palestinians. What do I mean by narrative? Not the grand narrative by which we position all understanding in the sequence of time. The

11 Eco, Umberto. "Interpretation and History." Interpretation and Overinterpretation. Ed. Stefan Collini. Cambridge: Cambridge UP, 1992. 30 
narrative here is more simply a story, an account of a sequence of events. This story in architecture can be read through the relationship between human action and metaphoric interpretation as shaped by our understanding of architecture and subsequently by our understanding of place.

History is a commodity. The many names of history, such as mainstream history, orthodox history, or conventional history, only hide the dominant perspective of those who preside over the major institutions of society. Throughout the ages, powerful nations and dominant classes have suppressed any history that does not reflect their own socio-economic interests. Through methods of filtration relative to positions of authority, history is created in the interests of its makers. ${ }^{12}$

Understanding the current architectural narrative, its political implications, and its relationship to Orientalism is important in changing the western image of Palestine and developing a narrative for a Palestinian nation. "Furthermore, it hardly needs saying that because the Middle East is now so identified with Great Power politics, oil economics, and the simple-minded dichotomy of a freedom-loving, democratic Israel and evil, totalitarian, and terroristic Arabs, the chances of anything like a clear view of what one talks about in talking about the Near East are depressingly small."13

Said often uses music as a metaphor in his linguistic discourse. In Said's book, Power, Politics and Culture, music is often used to illustrate and connect arguments. Edward's

12 Parenti, Michael. "Prologue: Against the Mainstream" History as Mystery. San Francisco: City Lights Books, 1999. 13 Said, Edward. Orientalism. New York: Vintage Books, 1979. Pg. 27 
example of the fugue which "can contain two, three, four, or five voices: they're all part of the same composition, but they're each distinct," ${ }^{14}$ exemplifies the type of narratives that can also be found in architecture, through such things as context, tectonics, light, and the relationship between movement, usage and space. Social, cultural and political agendas add to the story of the building, as well as the regional climate, history and surrounding landscape. These factors shape architecture to varying degrees but can be found present in all buildings to some extent. They form a narrative. Like in the fugue, these distinct voices come together to form a single composition. The fugue is a particularly interesting analogy in this context, as the word fugue comes from the Latin word meaning flight, or to flee.

In Culture and Imperialism, Said examines the novel as a powerful tool in shaping identity through narrative.

"The power to narrate, or to block other narratives from forming and emerging, is very important to culture and imperialism, and constitutes one of the main connections between them. Most important, the grand narratives of emancipation and enlightenment mobilized people in the colonial world to rise up and throw off imperial subjection; in the process many Europeans and Americans were also stirred by these stories and their protagonists, and they too fought for new narratives of equality and human community."15

14 Said, Edward. Power, Politics, and Culture. New York: Vintage Books, 2002. 91 15 Said, Edward. Culture and Imperialism. New York: Vintage Books, 1994. xiii 
The connection between the narrative of a novel and one's own political predisposition becomes more evident in Said's example of novels on the experience of Australia, an eighteenth century British penal colony. Beginning with Dickens's Great Expectations Said shows how the novel about Pip's self-delusion could be considered more attune to history than fiction. Criminals sent to Australia could begin a new life absolved from their crimes, "being from Australia, a penal colony designed for the rehabilitation but not the repatriation of transported English criminals". ${ }^{16}$ Criminals sent to Australia were seen to be capable of redemption but could never return to Britain.

Great Expectations reveals the relationship between the English criminal and the Aboriginal. The English criminal, although not accepted in Britain, could flourish within this new colony through such activities as travel and trade. The Aboriginal is set against the English criminal as a lower form of human being beyond any notion of rehabilitation. The English colonies are portrayed as new regions of potential profit, open to the dreams of the common man. The native Australians are portrayed as a lesser people, beyond law and rule, at best in need of intervention.

This reading of early English novels reveals cultural assumptions created through stories found in novels. These cultural assumptions, in the case of Great Expectations, marginalise the native Australians based on their subservient relationship to the dominant empire.

16 Said, Edward. Culture and Imperialism. New York: Vintage Books, 1994. xv 
It is marginalisation and territorial empowerment through narrative that I wish to explore in relation to the architecture of Palestine and the site proposed for the development of the National Library of Palestine, the Mukataa. As Said explains, there is no easy way to examine the relationship between knowledge and politics. Only through awareness that politics has and does play a role in what we accept as knowledge, as our conception of place and as our understanding of others, can the architectural discipline be critical when building upon the assumptions of the past. Said ends his book Orientalism with the aim that:

"...not so much to dissipate difference itself - for who can deny the constitutive role of national as well as cultural differences in the relations between human beings - but to challenge the notion that difference implies hostility, a frozen reified set of opposed essences, and a whole adversarial knowledge built out of those things. What I called for in Orientalism was a new way of conceiving the separations and conflicts that had stimulated generations of hostility, war, and imperial control."17

By shifting the architectural narrative of place, one can, over time, change the misrepresentation of Palestinians as hostile prisoners, an image that has lead to years of hostility and war in the region. 
Paul Ricoeur's work on narrative is a theory on interpretation. It stems from a position that life is relative to narrative and related to one's narrative identity through a process of interpretation and reinterpretation. This process, where the past is constantly interpreted and reinterpreted into the present, forms the basis of our identity. "Narrative identity, on this reading, is not just a psychological construct, but a composite of detailed memory and present re-evaluation." 18

Ricoeur sees the world as a text through which we understand ourselves and form our identity. This text that forms our narrative is in constant mediation "between the fictive world of the text and the actual world of the reader. The effects of fictions, effects of revelation and transformation are essentially effects of reading. It is by way of reading that literature returns to life, that is, to the practical and affective field of existence."19

David D. Brown, in his article On Narrative and Belonging, examines the work of Paul Ricoeur and his theory of narrative identity in relation to personal and collective identity.

"It is proposed that in the course of everyday interaction subjects find in the narrative accounts of others formal parallels with their own accounts. This line of thought will lead to an interpretation of the concept of collective identity as 'belonging'.,"20

18 Morny, Joy. "Introduction" Paul Ricoeur and Narrative: Context and Contestation. Calgary: University of Calgary, 1997. xxvi 19 Ricoeur, Paul. Time and Narrative, Volume III. Trans. Kathleen Blamey and David Pellauer. Chicago: University of Chicago, 1988. 101 20 Brown, David. "On Narrative and Belonging" Paul Ricoeur and Narrative: Context and Contestation. Calgary: University of Calgary, 1997. 109 
The experience of belonging happens through narrative discourse where the interpretation of self runs parallel to the interpretations of others. "What is understated is how I have knowledge of myself, not merely relative to others, but in relation to others."21

Knowledge of self, that forms the basis of one's reflection on identity, is not a given but is constantly emerging and developing. "Consciousness is accomplished not through unmediated self-reflection, but rather through the ongoing interpretation of cultural texts." 22

For Ricoeur, narrative forms the discourse that structures human identity. Through action and suffering narrative identity can be found in the stories we tell and the stories we hear. Or more simply, our identity becomes familiar as we recognize our stories in the stories of others. Self-interpretation is reflexive in that memory or social interaction directs and redirects one's interpretation of self. The space created by commonality is a product of converging life narratives. "In other words, the transition from personal identity (I) to collective identity (we) is a narrative accomplishment."23

Narrative can be understood as the story that coordinates our isolated individual experiences with the experiences of others. This coordination, through narrative, is the basis of community and the act of belonging.

\footnotetext{
21 Brown, David. "On Narrative and Belonging” Paul Ricoeur and Narrative: Context and Contestation. Calgary: University of Calgary, 1997. 110

22 Brown, David. "On Narrative and Belonging” Paul Ricoeur and Narrative: Context and Contestation. Calgary: University of Calgary, 1997. 111

23 Brown, David. "On Narrative and Belonging" Paul Ricoeur and Narrative: Context and Contestation. Calgary: University of Calgary, 1997. 115
} 
Paul Ricoeur believed that social theories, including history, are related to story telling. Ricoeur argues that history, in essence, is no different from story-telling except in the ways it is deployed, consumed, and reproduced as representations of objective reality or truth. History uses narrative construction in the same way as fiction, myth, and legend, the difference being the assumed relationship they have to the real world.

"We could ignore this dissymmetry by recalling the most striking results of my parallel studies of historical and fictional narrative, insofar as, in speaking of the configuration of time by narrative, the principal accent was on the mode of intelligibility the configurating power of narrative could claim rather than on the time that was at stake in it. For reasons that will appear only in the next volume, fictional narrative is richer in information about time, on this very plane of composition, than is historical narrative." 24

This implies that the generation and reproduction of an architectural narrative is an evolutionary process that takes place in the real world and is based on personal and institutional narrative constructions. These narrative constructions form the basis upon which we interpret meaning and derive knowledge.

24 Ricoeur, Paul. Time and Narrative: Volume 2. Trans. Kathleen Mclaughlin and David Pellauer. Chicago: University of Chicago, 1985. 158 
Graham Livesey explores the role of narrative and architecture. Using the theories of metaphor and narrative found in Paul Ricoeur's work, Livesey examines the relationship between human action and architecture.

"Ricoeur states in the preface to the first volume of Time and Narrative, that 'whereas metaphorical description reigns in the field of sensory, emotional, aesthetic, and axiological values, which make the world a habitable world, the mimetic function of plots takes place by preference in the field of action and its temporal values.' In his earlier text, the Rule of Metaphor, Ricoeur explores metaphor in rhetorical, structural and hermeneutical terms moving from the figural aspects of metaphor contained in a discussion of Aristotle to the existential implications of metaphor and 'the power to redescribe reality.' It is in the realm of metaphor that architecture more typically operates."25

Livesey concentrates on Ricoeur's use of figure as found in the work of Aristotle, where the word "figure" can be either a noun or a verb. "As a noun, it has a variety of meanings: a shape, a form, the human form, a likeness, a diagram, a symbol, a metaphor." Whereas "figure", as a verb, means "to bring into shape, to represent, to imagine, to portray, to perform a figure." 26 , Livesey uses Ricoeur's theory of emplotment, where the work of the poet is to create plots.

\footnotetext{
25 Livesey, Graham. "The Role of Figure in Metaphor, Narrative and Architecture" Paul Ricoeur and Narrative: Context and Contestation. Calgary: University of Calgary, 1997. 25 26 Livesey, Graham. "The Role of Figure in Metaphor, Narrative and Architecture" Paul Ricoeur and Narrative: Context and Contestation. Calgary: University of Calgary, 1997. 26
} 
"The first part of the model, Ricoeur labels as mimesis; he suggests that the 'composition of the plot is grounded in a pre-understanding of the world of action, its meaningful structures, its symbolic resources, and its temporal character. This refers to the practical world of everyday action, which Ricoeur describes as the realm in which stories or narratives are prefigured; narratives are based on actions that have motives, agents, and take place in the world and in time. As Ricoeur implies, architecture and spatiality can be considered as part of the world that prefigures narratives, as both meaningful structure and as symbolic systems."27

This suggests that architecture exists within a framework of narratives and informs those narratives by way of "emplotment." "In Ricoeur's model, this is the action of the poet, the production or making of stories or plots. It is also the aspect that coincides most closely with other forms of creative production such as design.",28

Livesey relates the task of the architect, which deals with shaping the design of a building within the context of everyday action. The cultural context, constraints, construction methods and limitations, economic concerns, languages of architecture, site, and program, Livesey argues, are the aspects of the prefigured narrative referred to by

27 Livesey, Graham. "The Role of Figure in Metaphor, Narrative and Architecture" Paul Ricoeur and Narrative: Context and Contestation. Calgary: University of Calgary, 1997. 26 28 Livesey, Graham. "The Role of Figure in Metaphor, Narrative and Architecture" Paul Ricoeur and Narrative: Context and Contestation. Calgary: University of Calgary, 1997. 27 
Ricoeur. "It can be suggested that architecture is both part of and emerges from a prefigured world."29

The process of creating a building is related to Ricoeur's theory of narrative emplotment summed up by Anthony Paul Kerby. "Emplotment, in histories and fictions, takes a prefigured world of events and actions and draws out or proposes a configuration that serves to organize worldly events into meaningful sequences and purposes. This textual structure is in turn the mediating cause of the reader refiguring his or her own world in light of the possibilities offered by experiencing the world of the work."30

Livesey advocates that the work of the architect is not a product of originality but instead the resulting form of a historical and cultural context, and to a large extent a response to a prefigured world. Examining the work of British architect Nigel Coates, Livesey shows how Ricoeur's theories are manifested in a work of architecture. In Coates' work the architect "gives shape to form based on an interpretation of the context and by creating narratives". 31 Livesey explains that the formal qualities found in architecture relate to the metaphorical dimension, while functional elements relate implicitly to narrative.

29 Livesey, Graham. "The Role of Figure in Metaphor, Narrative and Architecture" Paul Ricoeur and Narrative: Context and Contestation. Calgary: University of Calgary, 1997. 27 30 Livesey, Graham. "The Role of Figure in Metaphor, Narrative and Architecture" Paul Ricoeur and Narrative: Context and Contestation. Calgary: University of Calgary, 1997. 27 31 Livesey, Graham. "The Role of Figure in Metaphor, Narrative and Architecture" Paul Ricoeur and Narrative: Context and Contestation. Calgary: University of Calgary, 1997. 29 
"The use of figure, rather than form, as the basis for understanding architecture implies a history of shared meaning, a set of conventions or a comprehended language."32 This language is partly interpreted through the re-composition of the prefigured narrative, the emplotment, the metaphorical meaning, and the relationship of the user to the building that forms the narrative of the work. Moving through a building, one can plot a series of events in space. Whether choreographed or not, these events form a story.

"Our actions trace figures that can be retold in the narrative ordering of our life stories. Intersections between humans and their world (architecture), between each other and with ourselves, create the events that plot our journeys in time and space."33

32 Livesey, Graham. "The Role of Figure in Metaphor, Narrative and Architecture" Paul Ricoeur and Narrative: Context and Contestation. Calgary: University of Calgary, 1997. 29 33 Livesey, Graham. "The Role of Figure in Metaphor, Narrative and Architecture" Paul Ricoeur and Narrative: Context and Contestation. Calgary: University of Calgary, 1997. 33 


\section{Architecture as Metaphor}

Paul Ricoeur, in A Ricoeur Reader: Reflection and Imagination, examines aspects of metaphor in relation to literature. Ricoeur explains the theory of an exhausted metaphor, in which a metaphor offers no new information. Ricoeur refers to this type of metaphor as containing no information, a merely decorative device. Ricoeur shows how metaphor, through the act of confusion, can be used to establish new logic. Ricoeur argues that an informative metaphor is one in which the logical boundaries of language are confused. This confusion breaks the previously established categorizations and creates new logic that supersedes the existing understanding. ${ }^{34}$

Ricoeur notes the complications in understanding meaning from a given language. As all words can be interpreted in a variety of ways, a text can convey a variety of different meanings. This is the problem of interpretation.

"The simplest message conveyed by the means of natural language has to be interpreted because all the words are polysemic and take their actual meaning from the connection with a given context and a given audience against the background of a given situation. Interpretation in this broad sense is a process by which we use all the available contextual determinants to grasp the actual meaning of a given message in a given situation." 35

\footnotetext{
34 Ricoeur, Paul. "Word, Polysemy, Metaphor: Creativity in Language.” A Ricoeur Reader: Reflection and Imagination. Ed. Mario J Valdes. Toronto and Buffalo: University of Toronto Press, 1991. 81

35 Ricoeur, Paul. “Word, Polysemy, Metaphor: Creativity in Language." A Ricoeur Reader: Reflection and Imagination. Ed. Mario J Valdes. Toronto and Buffalo: University of Toronto Press, 1991. 71
} 
Interpretation through metaphor can reveal relationships or links that are inventions of circumstance. The architect choreographs this circumstance found in architecture.

"Metaphor helps us to detect this process because it works against previous categorization at the level of rhetoric. It cleverly bypasses given categories in order to reveal unnoticed similarities in the field of our experience.,36

Metaphor reveals ontological links that are inventions of circumstance. This plurality of meaning, understood in its newfound context, bends our sense of truth and knowledge. "When we receive a metaphorical statement as meaningful, we perceive both the literal meaning which is bound by the semantic incongruity and the new meaning which makes sense in the present context." ${ }^{37}$ Metaphor in architecture is an illusive concept. In relation to Livesey's explanation of Ricoeur's theories of prefiguration and emplotment, metaphor can reveal a language that exists beyond the surface of the text.

In the end, this narrative of architecture examined by Livesey comes down to aspects of interpretation. "Interpretation in this broad sense is a process by which we use all the available contextual determinants to grasp the actual meaning of a given message in a

\footnotetext{
36 Ricoeur, Paul. "Word, Polysemy, Metaphor: Creativity in Language." A Ricoeur Reader: Reflection and Imagination. Ed. Mario J. Valdes. Toronto and Buffalo: University of Toronto Press, 1991. 82

37 Ricoeur, Paul. "Word, Polysemy, Metaphor: Creativity in Language." A Ricoeur Reader: Reflection and Imagination. Ed. Mario J Valdes. Toronto and Buffalo: University of Toronto Press, 1991. 83
} 
given situation." 38 This is not a simple task. As Ricoeur reminds us, "even the simplest message conveyed by the means of natural language has to be interpreted because all the words are polysemic and take their actual meaning from the connection with a given context and a given audience against the background of a given situation." 39 Polysemic is defined by Ricoeur as, "that remarkable feature of words in natural languages which is their ability to mean more than one thing." 40

As the context of a given architecture changes, so too will the given metaphors and narratives associated with it. Architects can imagine what this future may hold but, in the end, can only react to what Ricoeur argues is a prefigured culture in which the actions of today are constantly negotiated by the interpretation of the past.

38 Ricoeur, Paul. "Word, Polysemy, Metaphor: Creativity in Language." A Ricoeur Reader: Reflection and Imagination. Ed. Mario J. Valdes. Toronto and Buffalo: University of Toronto Press, 1991. 71 39 Ricoeur, Paul. "Word, Polysemy, Metaphor: Creativity in Language." A Ricoeur Reader: Reflection and Imagination. Ed. Mario J Valdes. Toronto and Buffalo: University of Toronto Press, 1991. 71

40 Ricoeur, Paul. “Word, Polysemy, Metaphor: Creativity in Language.” A Ricoeur Reader: Reflection and Imagination. Ed. Mario J Valdes. Toronto and Buffalo: University of Toronto Press, 1991. 65 


\section{Archaeological Myth and Architectural Metaphor}

"History is extruded from tales that have become cultural commodities, even and especially where historical themes are exploited. History as such becomes a costume identified with the individual concealing the frozen modernity of monopoly and state capitalism." 41

Walls are used as physical manifestations, signifiers of once-imagined boundaries in space. As a wall ages, it accumulates history, it becomes cultural, it is a costume that identifies. A perfect example of this is found at the Western Wall in Jerusalem. The Western wall exemplifies the use of narrative and metaphor in developing a national identity.

The historic tales surrounding the Western Wall at Temple Mount are the unifying belief, the identity used to rationalize the creation of Israeli nationalistic claims. The excavations of the Western Wall at Temple Mount are, in fact, an attempt to give concrete foundation to historic belief. The question is, to what extent are these excavations, performed at a high cost - namely the destruction of many Palestinian dwellings - successful in terms of delivering historic validity? Are the excavations a search to legitimize Judeo fiction surrounding the secular state of Israel through the search for the Temple of Solomon? Are the excavations simply part of a capitalist

41 Adorno, Theodor. "The Schema of Mass Culture." The Culture Industry; Selected Essays on Mass Culture. Ed. J.M. Berstein. London and New 
agenda targeting the contemporary consumer of history by supporting archaeologically based research for the historic tourist to exploit?

At first glance, the excavations taking place between 1969 and 1970 appear to be an attempt to construct a seemingly objective archaeological history. However, the arguments often seem to contain only fictional validity based on historic architectural myth, the many fragments failing to successfully illuminate an objective secular history.

Archaeological evidence in Jerusalem dates back to 3000 BCE. A time that Jerusalem was referred to as Jebus, referring to the Jebusite people who lived there. The interpretation of texts of this period are widely disputed and rarely objective. Many authors argue that the traditional narrative of this period is not historical. The religious tradition is a series of discredited translations that make convenient connections in the storyline. $^{42}$

As interpreted in the Old Testament, in response to God's command 2000 years before the common era (BCE), Abraham journeys three days from Beersheba to Mount Moriah in Jerusalem to offer his son Isaac as a sacrifice. God provides a ram as a substitute. 1000 years later, King David conquers the Jebusites and chooses to erect an Alter of sacrifice on Mount Moriah. ${ }^{43}$

42 Asali, KJ. Jerusalem in History “Jerusalem in the Bronze Age 3000-1000BC”. England: Scorpion Publishing, 1989. 43 Avi-Yonah, Michael. Jerusalem. Israel: Keter Publishing House, 1973 
The site where David erected the Alter of sacrifice becomes the site of the First Temple. It was under the reign of David's son, King Solomon (965-928 BCE), that the plans for the First Temple, sanctuary for the Holy Ark, and adjacent royal palace were developed. The First Temple took twenty years to complete. ${ }^{44}$

Since King Solomon had neither the materials nor the trained workers to build his plans, Solomon entered into negotiations with Hiram of Tyre. Hiram provided the timber, skilled workmen, stonemasons, and carpenters from Gebal in exchange for oil and corn from King Solomon. ${ }^{45}$

Many architects searching through biblical writings for clues have sought to imagine what this temple might have looked like. The variety of resulting plans shows the wide range of interpretation possible through the use of biblical narrative.

The First Temple was destroyed, leaving not a single remnant of its splendour.

Nebuchadnezzar and his Babylonian forces conquered the land, devastated Jerusalem, and looted and burned the First Temple that had been built by Solomon and Hiram. ${ }^{46}$ King Cyrus of Persia captured Jerusalem from the Babylonians and is credited with erecting the Second Temple. In $538 \mathrm{BCE}$, a proclamation by King Cyrus permitted the

\footnotetext{
44 Kroyanker, David. Jerusalem Architecture. New York: Vendome Press, 1994.

45 Parrot, Andre. The Temple of Jerusalem. London: 1957.

46 Asali, KJ. Jerusalem in History "Jerusalem From 1000-63BC". England: Scorpion Publishing, 1989.
} 
exiles to return to Jerusalem. It was during the ensuing Persian Period that the Second Temple was built. ${ }^{47}$

Under the leadership of Nehemiah, the Second Temple was standing by 515 BCE and the pagan rituals that King David began continued within its sacred walls. In the following years the Second Temple was conquered by the Greeks, under Alexander the Great (332 BCE), then the Ptolemies of Egypt (301-198 BCE), followed by the Syrian Seleucids, each adapting the Temple for their own agendas. ${ }^{48}$

The Hasmoneans took possession of Jerusalem from the Seleucids and cleansed the Temple of pagan objects in December 164 BCE. This date is particularly important as it pertains to the 'Feast of Dedication' or Hanukkah. In 64 BCE the Romans, under general Pompey, breached the Temple and took control of Jerusalem. The Romans murdered Jews, plundered Jerusalem, and largely destroyed the Second Temple. Much destruction and looting of the city took place until the rule of King Herod in 37 BCE. ${ }^{49}$

King Herod feared the Jews because he had strong ties with hated Romans. To appease the people, Herod rebuilt the Second Temple and lavishly adorned it in rich materials. King Herod's Second Temple stood for nearly a century, during which time Jesus of

\footnotetext{
47 Kroyanker, David. Jerusalem Architecture. New York: Vendome Press, 1994 48 Kroyanker, David. Jerusalem Architecture. New York: Vendome Press, 1994. 49 Avi-Yonah, Michael. Jerusalem. Israel: Keter Publishing House, 1973.
} 
Nazareth was executed under Pontius Pilate. Jerusalem thrived during the Herodian period until, in $70 \mathrm{CE}$, the Second Temple was destroyed by the Roman General Titus. ${ }^{50}$

Following the Second Temple's destruction at the hands of General Titus, Emperor Hadrian built a complete Roman town called Aelia Capitolina. Hadrian barred Jews from entering the city. The Roman period continued building many monumental Christian structures during what is known as the Byzantine period that lasted till $638 \mathrm{CE}{ }^{51}$

The Islamic period began in $638 \mathrm{CE}$, five years after the death of the prophet Muhammad. The Caliph 'Umar received the message that the Roman town of Aelia Capitolina would surrender to the Muslims if they guaranteed the safety of the people, their property, and their churches. ${ }^{52}$

Caliph Omar Ibn Khattab built Al-Haram El-Sharif, the Dome of the Rock on the Temple Mount, between 660 and $691 \mathrm{CE}$, claiming that it was the place where the prophet Muhammad came for his night ascent to heaven. Jerusalem was recognized as the third holiest city in Islam, after Mecca and Medina, and as a destination for pilgrimage. ${ }^{53}$

50 Holum, Kenneth G., Robert L. Hohlfelder, Robert J. Bull, and Avner Raban. King Herod's Dream: Caesarea on the Sea. New York: W.W. Norton and Company, 1988. 59 51 Kroyanker, David. Jerusalem Architecture. New York: Vendome Press, 1994. 52 Asali, KJ. Jerusalem in History "Jerusalem in the Early Islamic Period 7th-11th Centuries AD". England: Scorpion Publishing, 1989. 
During the following years many cultures and empires added to the architectural fabric of Jerusalem including the European Crusaders (1099-1187), the Salah al-Din (1187-1259), the Mamluk Period (1260-1517), and The Turkish or Ottoman Empire (1517-1917). ${ }^{54}$

Entering the $20^{\text {th }}$ century in 1917 , the British army entered Jerusalem under General Allenby. Jerusalem was under the British mandate from 1917 to 1948. After the Second World War, Palestine was given over to become the state of Israel. However, Jerusalem still remained under Jordanian control. ${ }^{55}$

On June 11, 1967, the Palestinian inhabitants of the al-Magharib, or Moroccan quarter in Jerusalem, an area adjacent to the Western Wall, were ordered to evacuate their homes. Israeli army engineers lay down and detonated explosives in their homes and courtyards; bulldozers drove though the Dung Gate and proceeded to clear the rubble. When the dust had settled, a large plaza leading to the great Herodian blocks of the Western Wall was revealed. The only remnant of the former quarter was a Sufi zawiya, a Moslem building type where a Sufi sheikh receives his brotherhood. The zawiya, perched above ground level and clinging to the entrance to al-Haram al-Sharif, was subsequently demolished for "safety reasons." 56

\footnotetext{
54 Kroyanker, David. Jerusalem Architecture. New York: Vendome Press, 1994.

55 Yadin, Yigael. Jerusalem Revealed: Archaeology in the Holy City 1968-1974. New Haven and London: Yale University Press and the Israel

Exploration Society, 1976. 131

56 Dumper, Michael. The Politics of Jerusalem Since 1967. New York: Columbia University Press, 1997. 161-162.
} 
To Jews and Israelis, the creation of the plaza was a wonderful sight. Cut off from their holiest site for years, they could not only return but also congregate unimpeded and in large numbers. To Muslims and Palestinians, on the other hand, it left a frightening and sickening feeling. One hundred and thirty-five homes as well as the ancient Buraq and Afdali mosques had been destroyed. Approximately 650 people had been evicted without warning, the numbers varying depending on whose account, between 200 and 1000 families. For the Palestinians, their relatives, and the Arab population of the newly occupied city, the razing of the Magharib quarter with its two mosques, zawiya, and endowed residential and commercial property, was a chilling introduction to the new Israeli era. $^{57}$

Israeli responses to this act are interesting. Benvenisti, in his book Jerusalem: Torn City justified it in the following terms:

" the move was the settling of an historic account with those who had harassed the Jewish people over the centuries, restricting it and humiliating it at its holiest place, as well as with those who had prevented access to the wall for nineteen years. The displaced inhabitants of the Magharib quarter were not personally to blame, but it was their fate to be additional victims of the Arab-Israeli conflict.", 58

Yosef Schweid, the municipal architect and town planner, expresses it similarly:

57 Dumper, Michael. The Politics of Jerusalem Since 1967. New York: Columbia University Press, 1997. 161-162. 58 Benvenisti, Meron. Jerusalem: The Torn City. Minneapolis: University of Minnesota Press, 1976. 307 
“ it was not just the practical aspect - the need to absorb large numbers of people [in front of the Wall], which was the deciding factor here; even more important was the sense of the historic necessity of the act, a sense of expiation and restitution, and that was what motivated the decision. " 59

The destruction of the Magharib quarter created new opportunities for archaeological exploration, work that was subsequently reported in two journals written in 1970 entitled: The Excavations in the Old City of Jerusalem Near the Temple Mount by Mazar; and, The Omayyad Structures Near the Temple Mount by Ben-Dov. These documents describe the archaeological excavations that took place between 1969 and 1970 around the western wall at the Temple Mount. These excavations were subsequently covered to a large extent by the large courtyard and public gathering area on the western side of the Temple Mount.

Mazar and Ben-Dov, through archaeology demonstrate the various strata of occupations in Jerusalem. The findings by Mazar and Ben-Dov are examined in relation to the writings of Flavius Josephus who wrote Antiquities of the Jews; A History of the Jewish Wars. In 1970, it was believed that the Western Wall at the Temple Mount was the last remaining wall of the Temple of Solomon. Although the work of Josephus was thought to be historical, scholars and religious authorities omitted his accounts of the Second Temple's destruction as exaggerations. Ernest L. Martin, a contemporary archaeologist, worked with both Benjamin Mazar and Meir Ben-Dov as a young man. At that time 
Martin also accepted that the Western Wall at Temple Mount was the last standing evidence of the Second Temple. However, in 1997, he along with many others realized Josephus was not exaggerating the extent to which the Second Temple was demolished. ${ }^{60}$

Josephus states:

" It [Jerusalem with its walls] was so thoroughly laid even with the ground by those that dug it up to the foundation, that there was left nothing to make those that came thither believe it [Jerusalem] had ever been inhabited." 61

If the foundations of the Second Temple were demolished than what is standing before us today is not the last wall of the Second Temple.

Josephus states what Titus saw:

"As he came to Jerusalem in his progress [In returning from Antioch to Egypt], and compared the melancholy condition he saw it then in, with the ancient glory of the city [compared] with the greatness of its present ruins (as well as its ancient splendor). He could not but pity the destruction of the city..." 62

60 Martin, Ernest L. The Temples that Jerusalem Forgot. Portland: ASK Publications, 2000.

61 Whiston, William. The Life and Works of Flavius Josephus. New York: Holt, Rinehart and Winston, 1936. War VII.1,1 62 Whiston, William. The Life and Works of Flavius Josephus. New York: Holt, Rinehart and Winston, 1936. War VII.5,2. 
If we examine both the accounts of Titus and the writings of Josephus, as well as contemporary archaeological reconstructions of the edifice in Jerusalem, the large ashlars of the Western Wall at Temple Mount (Haram esh-Sharif) are the remains of the Fort Antonia used by the Romans during the Roman occupation, a period shortly after the destruction of the Second Temple. The Jews loathed the Romans, as well as Fort Antonia. During this period, the Jews were exiled from Jerusalem and many atrocities were committed against them.

The Second Temple would stand to the south of Temple Mount but was completely uprooted and demolished. Standing from the Mount of Olives looking towards the Temple Mount one sees the Haram esh-Sharif and does not see the demolished Second Temple or any remnants of its existence as Josephus states. Therefore, the contemporary pilgrim tends to superimpose one history onto another monument. ${ }^{63}$

The most visible connection between tourism and religion consists of thousands of sacred buildings that tourists chose to visit. According to Vukonic: "The reason for their interest is increasingly to be found in the cultural content of historical value of the sacred building, rather than its original religious purpose." 64

On the whole, pilgrims do not tend to complain about the touristic and commercialised nature of sites and their lack of historic authenticity, but are more concerned with the 
contemporary meaning the site offers them. ${ }^{65}$ If we accept that archaeology has established that the Western wall at the Temple Mount in the past was not a building sacred to the Jews, than one could speculate that the meaning of the wall comes not from its historic value but from its metaphoric architectural meaning.

Cohen describes the problems related with tourism as a search for secular cultural foundations in outlining a sociology of international tourism:

"mass tourism as a cultural phenomenon evolves as a result of a very basic change in man's attitude to the world beyond the boundaries of his native habitat. So long as man remains largely ignorant of the existence of other societies, other cultures, he regards his own small world as the cosmos. What lies outside is mysterious and unknown and therefore dangerous and threatening. It can only inspire fear or, at best, indifference, lacking as it does any reality for him." 66

Stemler explains both to himself and to his readers the reason for his indifference towards Jerusalem:

"Perhaps, the anticipation of the event was too strong. Having imagined
goodness knows what, I saw an unprepossessing wall, built up of ancient stones.

65 Collins-Kreiner, N. and N. Kliot. Pilgrimage Tourism in the Holy Land: The Behavioural Characteristics of Christian Pilgrims. Netherlands: Kluwer

Academic Publishers, GeoJournal 50: 60-61 (2000)

66 Epstein, Alek D. and Nina G. Kheimets. Looking for Pontius Pilate's Footprints Near the Western Wall: Russian Jewish Tourists in Jerusalem. USA:

Tourism, Culture and Communication, Vol. 3 43. (2001) 
If one's soul has not been imbued with the essence of Judaism, if one's religious knowledge is less than modest, then the asceticism of a ritual suppresses one's delight. Christianity is quite another matter. The pomposity of buildings, their architecture, the rituals, the splendour of clergymen's clothes, the organ sounds, all these inspire one with trepidation... At any rate, while I was standing near the Western Wall, my mind accepted my People's history, yet my soul remained deaf to it. And I blamed myself for this deafness." 67

Tourists go on a contemporary pilgrimage making sure to include the attractions that authenticate their journey. Various theorists of tourism perceive that museums, such as, the British Museum and the Louvre, are often visited by tourists as landmarks to confirm that one has truly been to a place. These landmarks represent the key symbols which mark the achievement of the tourist.

Museums act as secular temples or ancestral places, the focus of which, analogous to the religious relic, is the sacredness of the work of art or the authentic object. ${ }^{68}$ The museum on its own is not the reason for travel but part of the contemporary pilgrimage. The pilgrimage, in essence, is a journey for education or grounding. This search for cultural foundations and worldly understanding leads to condensed interpretations of the natural

\footnotetext{
67 Epstein, Alek D. and Nina G. Kheimets. Looking for Pontius Pilate's Footprints Near the Western Wall: Russian Jewish Tourists in Jerusalem. USA:

Tourism, Culture and Communication, Vol. 3 49. (2001)

68 Golden, D. The Museum of the Jewish Diaspora Tells a Story: The Tourist Image "Myths and Myth Making in Tourism"

Chichester: John Wiley

and Sons, 1996. 224.
} 
and cultural heritage of the place that they are visiting. On the whole, museums can be seen by the tourist to provide one such locus in the metaphoric fabric of culture.

Israel is an established and frequented tourist destination. By the 19th century travel to the Holy Land was already popular. The number of tourists visiting Israel after its establishment in 1948 grew slowly at first, from 22,000 in 1949 to about 42,000 in 1957. As a result of the development of air transportation and increased government support, tourism grew rapidly from 1957, reaching 290,000 in 1967. After the six-day war in 1967, visitation continued to accelerate with arrivals exceeding 650,000 in 1971 and rising to 2 million in $1997 .^{69}$

For tourists or pilgrims, the Western Wall symbolizes the last remaining wall of the Second Temple, the location of the temple of Solomon, as well as the memory of exile and the glory of religious domination. The historic validity of the wall does not change the meaning as understood by its viewers. Architecture does not carry an inherent truth but a multitude of archaeological myth and metaphoric meaning. Meaning is not secular or objective but a constructed theory based on historic interpretation. The Western Wall's architectural metaphor challenges the objective nature of secular history. The excavations did not legitimize Judeo fiction surrounding the secular state of Israel, but in the end revealed the anonymity of the Temple of Solomon. As a capitalist agenda

69 Epstein, Alek D. and Nina G. Kheimets. Looking for Pontius Pilate's Footprints Near the Western Wall: Russian Jewish Tourists in Jerusalem. USA: 
targeting the contemporary consumer of history, the Wall functions as a metaphor, imparting its meaning through archaeological myth.

Keith Whitelam's book the Invention of Ancient Israel bearing the subtitle The Silencing of Palestinian History accuses biblical scholars of helping to dispossess the Palestinian people of their history, identity and land. Keith Whitelam links biblical scholarship to the contemporary social and political context. He shows how the view of people relative to their social and religious identities serves as an origin and predisposition that influence their objectivity. This religious predisposition projects current social and political ideologies onto historical narratives, making the re-composition of the past nearly impossible. "The construction of an ancient Israel and an ancient settlement of the land by means of an uncritical, paraphrastic history fuses academic historicism with religious ethnic memory.",70

Whitelam, as well as other de-constructivists, argue that a suppression of a contemporary Palestinian social identity and the support of an Israeli Jewish identity are implicated in the ways that the study of the history of a region gets associated with the study of the Biblical text. This is important as the study of history can be linked to current territorial claims such as that of the Western Wall and by extension Jerusalem and Israel.

"During the Hellenistic period, at a time when interest in national and ethnic origins was running high, the myth then instigated one of several accounts of the

70 Zwelling J. The Fictions of Biblical History. History and Theory, February 2000, Vol. 39, 
initial Israelite occupation of the Palestinian hill country supposedly empty of inhabitants. Together with the alternative version represented in the book of Joshua, and corroborated by a number of subsidiary myths (e.g.about the ethnic origins of the indigenous peoples), it served in due course as historical legitimation for an exclusive claim to territory, at least in the sense that others could share space only on conditions established by those who claimed to be the original settlers." ${ }^{, 71}$

Whether we accept the legitimacy of a history based on theological interpretation or not, it is worth the trouble to examine the territorial politics that have become increasingly apparent with respect to notions of origin and identity. These myths have become key factors in the mobilization of political power in which archaeology can serve to substantiate national-territorial agendas.

\section{As Blomley shows in Law, Property, and the Geography of Violence, "Property} discourse offers a dense and pungent set of social symbols, stories, and meanings. The formation of national identity is, in part, a meditation on the meanings and significance of land as property." 72 As such, the Moroccan quarter adjacent to the Western Wall was seen as an obstacle towards the creation of the large plaza to be used in the consumption of sacred space and a symbol of national identity. The new maps created thereafter showed the enlarged Jewish quarter with no mention of the previous inhabitants. This

\footnotetext{
71 Blenkinsopp J. The Bible, Archaeology and Politics; or The Empty Land Revisited. Journal for the Study of the Old Testament, 1 December 2002, Vol. 27, No. 2,187

72 Blomley, Nicholas. Annals of the Association of American Geographers, "Law, Property, and the Geography of Violence: The Frontier, the Survey and the Grid". 93(1). 2003122
} 
shift in the zoning and ownership of the Moroccan quarter gave new legitimacy to the Western Wall. The inhabitants where termed to be squatters, excluded from the ethics of state. This aspect added to the detached view of the military operations.

Francois Debrix explains how knowledge is not only derived from objective sources, but is also found in a variety of cultural media. "Power struggles and rivalries are embedded in identity debates" ${ }^{73}$. The large plaza, through images of mass gatherings became a window for the world, a sort of propaganda by which the production of identity and belonging could flourish. "In an age dominated by tabloid journalistic productions and 'trash' entertainment, popular cultural signs and artefacts become desirable channels of knowledge" 74

\section{Popke in Poststructuralist Ethics: Subjectivity, Responsibility and the Space of}

Community examines ethical thinking, poststructuralism, and deconstructivism in relation to geopolitics. The figure of the stranger creates dualisms between self and other, between here and there, inclusion and exclusion, presence and absence, in-place and out-of-place. Popke states that: "Perhaps the overriding sentiment within this work is a widely noted 'distrust of metanarratives' governing theoretical systems, and a healthy scepticism toward the universality of truth and knowledge claims." 75 This can be seen in the work of Keith Whitelam discussed above and his critique of biblical history as it relates to notions of identity and contemporary politics.

73 Debrix, Francois. "Tabloid Realism and the Revival of American Security Culture" Geopolitics 8(3). 2003. 162. 74 Debrix, Francois. "Tabloid Realism and the Revival of American Security Culture" Geopolitics 8(3). 2003.182. 75 Popke, Jeff. Progress in Human Geography, "Poststructuralist Ethics: Subjectivity, Responsibility and the Space of Community". 27(3). 2003. 299 
The Moroccan quarter became an enemy. Through 'strategic exclusion', it was outside the moral and ethical boundaries of the state. Imagined identities continue to be specific to geopolitical boundaries and modern sovereign states. It is these identities that tend to exclude certain residents from a seemingly ethical democracy. Though we may agree with Bowden that, "Democracy is said to be the best form of government for promoting economic development; and the best means of maintaining a stable democracy is via sustained economic growth" 76 , we must question who is excluded from such democracies that legitimize atrocities for the sake of economic growth. The ethical cost of maintaining illusions of homogenous identity, often key in maintaining a stable democracy, camouflages the multivalent reality of contemporary states.

Walker shows how traditional ideas of territorial sovereignty have changed. The lines of authority relative to notions of sovereignty are not relative to territorial boundaries. The notion of sovereignty crosses borders, as the contemporary individual's identity is plural and multi-territorial. As such, sovereignty was extended beyond the regional boundaries of Jerusalem to include the needs of tourists, who temporarily became part of the sovereign state to create consensus and give legitimacy to political acts of violence, as seen through the eviction of the inhabitants of the Moroccan quarter.

"In the context of multiply contested but at least intermittently plausible claims about globalization, it is difficult to suppose that democratic accounts of

76 Bowden, Brett. "In the Name of Progress and Peace: The "Standard of Civilization" and The Universalizing Project" Alternatives 29(1). 2004. 45 . 
legitimate authority can be contained within monolithic territorial boundaries. In a world of movement, multiple identities, and all the rest, one should probably look at the ways in which the concept of citizenship is being rearticulated in multiple contexts."77

Cosmopolitanism legitimizes colonial tendencies through notions of utopian global democracy. It views the individual as a product of territorial cross-fertilization. As such, people can be seen to belong to a range of polities and enjoy multiple citizenships.

Cosmopolitanism today is often found in media headlines and urban ethnicity packaged for consumer markets. Cosmopolitanism rarely dissolves the hierarchy of power relations within a state. It maintains the imagined cultural divisions simply giving power to those who can organize themselves into greater numbers across boundaries. Calhoun shows how cosmopolitanism is often found in the pursuit of capitalism not democracy.

"To appeal simply to liberal individualism - even with respect for diversity - is to disempower those who lack substantial personal or organizational resources. It is also disingenuous, if would-be cosmopolitans don't recognize the extent to which cosmopolitan appreciation of global diversity is based on privileges of wealth and perhaps especially citizenship in certain states." 78

77 Walker, R.B.J. "Polis, Cosmopolis, Politics" Alternatives 28(2). 2003. 282.

78 Calhoun, Craig. "The Class Consciousness of Frequent Travellers: Towards a Critique of Actually Existing Cosmopolitianism" in Daniele Archibugi (ed.) Debating Cosmopolitics London: Verso, 2003, 112. 
"But few of the categorical identities that express people's sense of themselves are matched to strong organizations of either power or community at a transnational level." 79 Those that are seem only to be linked to aspects of representation, in so far as they can be exploited for economic markets of consumption, often, as in the case of Jerusalem and the Moroccan quarter, at the cost of reducing a community to a single metaphoric image not representative of the community at large.

"Not only is the definition of 'people' problematic, the idea of representation is extremely complex. Representing peoples has been one of the primary functions of modern states - however great the problems with how they do it." 80

The Destruction of the Moroccan quarter was the articulation of regional identity and regional economy along narratives of cultural territorial difference for economic power. In Regions Unbound: Towards a New Politics of Place, Amin proposes a political democracy of place based, not on the imagined regional identity of territory, but on a plurality of voices. Through new public organizations, Amin's proposal seeks to decentralize authority and allow the multi-ethnic, multicultural, heterogeneity and difference found in spaces to be voiced. "The result is a regional 'inside' constructed through public debate over particular political programs or visions of the good life." 81

\footnotetext{
79 Calhoun, Craig. "The Class Consciousness of Frequent Travellers: Towards a Critique of Actually Existing Cosmopolitianism" in Daniele Archibugi

(ed.) Debating Cosmopolitics London: Verso, 2003, 100.

80 Calhoun, Craig. "The Class Consciousness of Frequent Travellers: Towards a Critique of Actually Existing Cosmopolitianism" in Daniele Archibugi (ed.) Debating Cosmopolitics London: Verso, 2003, 97.

81 Ash Amin, Ash. "Regions Unbound: Towards a New Politics of Place" Geografiska Annaler B 86. 2004,41
} 
This proposal, on the surface, may seem utopian and perhaps impossible, as those with power tend not to wish to relinquish such power and diversify political structures. As well, one organization's economic agenda often conflicts with that of another as the destruction of the Moroccan quarter demonstrates. However, when examining global places such as Jerusalem, Amin's proposal seems well suited to the plurality of place. While a new public organization based on decentralized authority cannot in and of itself address the social problems of Jerusalem, such as the strong territorial religious divisions, it begins to address a part of the solution, giving hope by daring to imagine a future which is better than the one we are experiencing today.

Examining the work of Mazar and Ben-Dov in contrast to contemporary archaeologist Ernest L. Martin, archaeology appears to be mythical in nature, the many fragments failing to illuminate a totality. The authenticity of the Western Wall as the last remaining wall of the Second Temple is uncertain. However, the wall's historic validity does not infringe upon its contemporary architectural meaning. For the consumer of history, the Western Wall functions as a metaphor, imparting its meaning through archaeological myth. Meaning in architecture is derived through metaphoric interpretation, not history. Mobilized by political motives, sovereignty, in the case of Jerusalem, led to the destruction of the Moroccan quarter, the destruction of private property and the extension of public property and the commercial potential of the nation state. By discriminating against the inhabitants of the Moroccan quarter the state created a dichotomy between the included and the excluded. Within the context of globalisation and the discourse on cosmopolitanism, Israel was able to incorporate the needs of the greater diaspora to 
legitimize the economic motives of the regional community. Through the leveraging of religious historical narratives, based on architectural remnants, related through metaphor to identity, origin and exile, the government was able to pursue socio-political economic agendas. Archaeology in the case of Jerusalem does not present clear objective histories of origin, but presents the reality of over 3000 years of human occupation in which land and buildings form a complex relationship where structures and territories are used, reused and re-appropriated by many peoples and cultures who exist in a much more cross-fertilized anthropology than the one often advocated by nationalist agendas. 


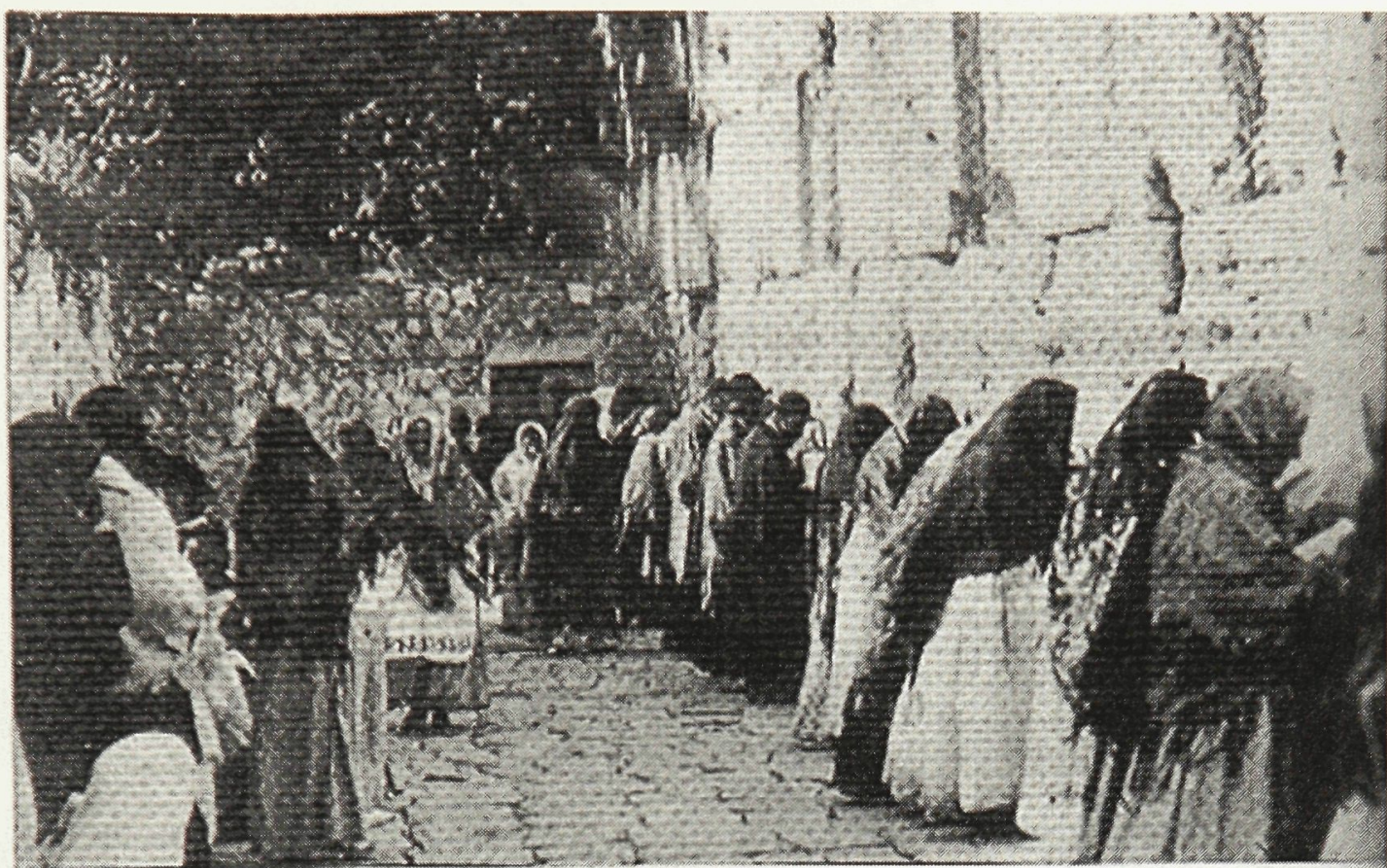

Western Wall - The Wall in the carlier part of the century.

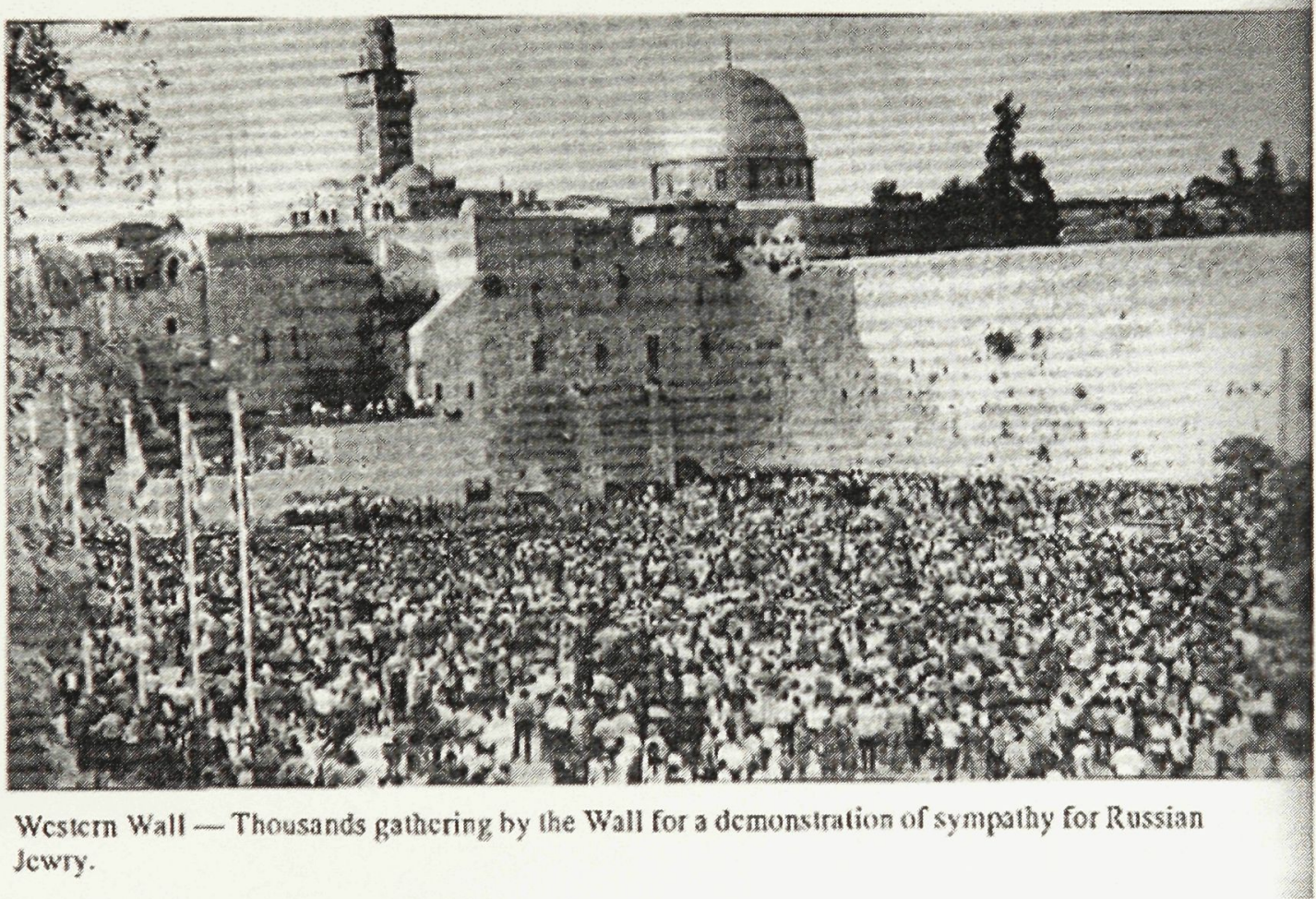

(above) People gathering at the wall in the earlier part of the century. (below) People gathering at the wall in the later part of the $20^{\text {th }}$ century. ${ }^{82}$ 

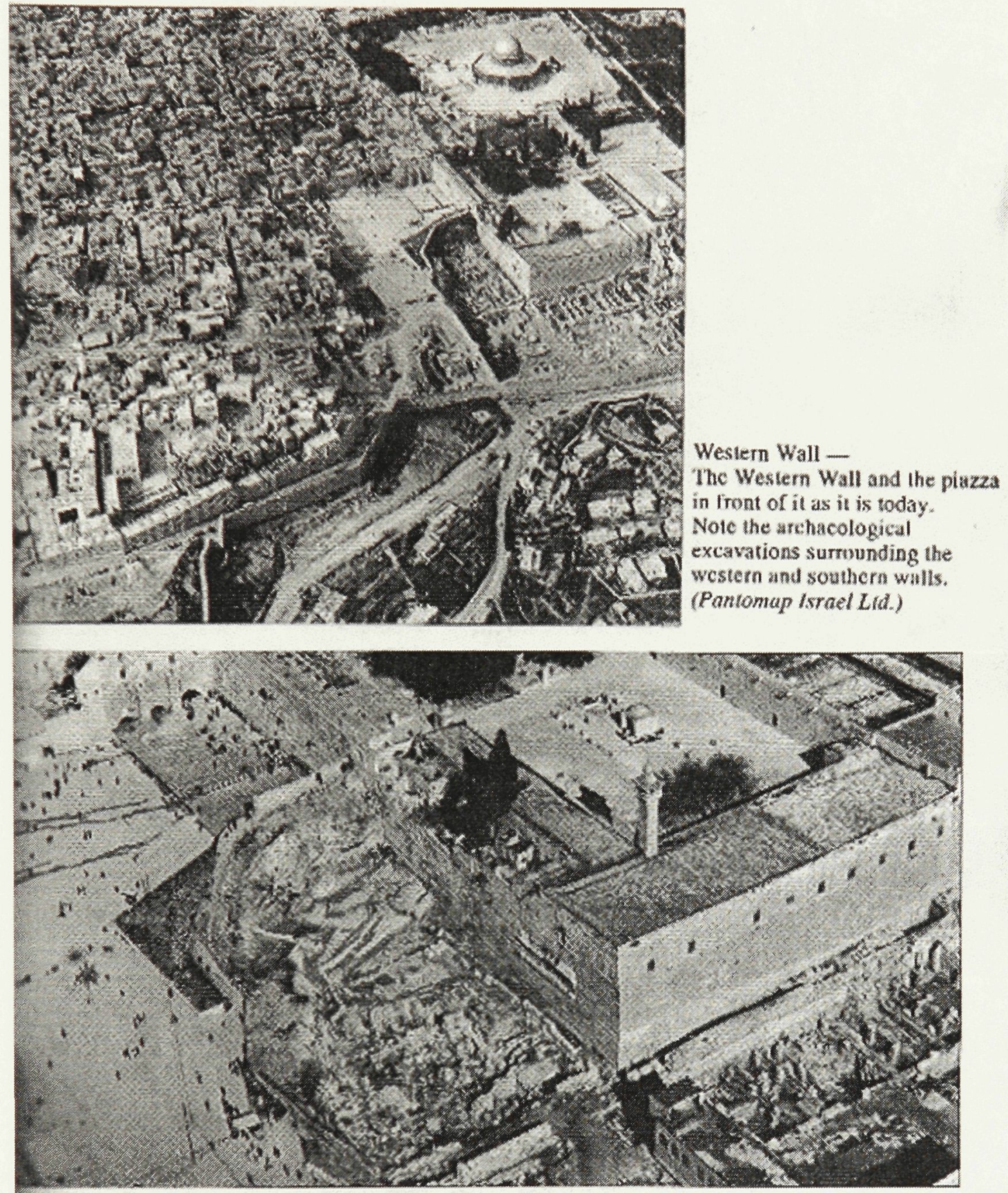

Wall Now Details of the makeshif conditons by the Wall, 1975. The praying area has - ated and paved; the archacological excavations exntinue th the west and south. The cdge

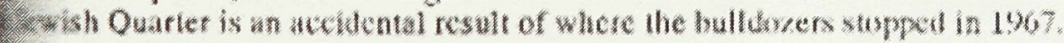
- Isracel Lid.)

(above \& below) Ariel view of the Western Wall and the plaza in front 


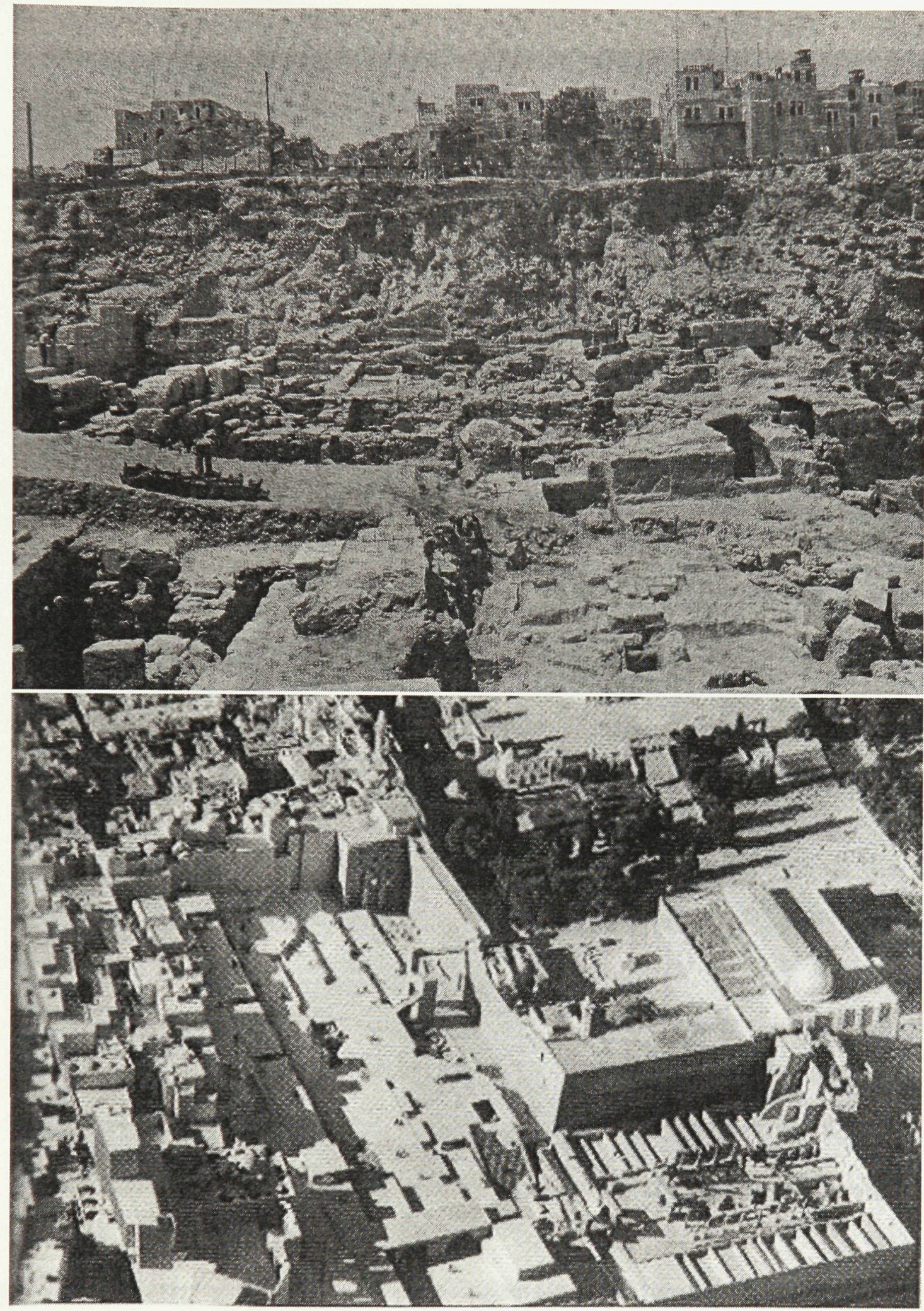

(above) View of the archaeological excavation adjacent to the western wall ${ }^{84}$

(below) View from above the model, showing the future plans for the gathering space adjacent to the Western Wall. ${ }^{85}$

84 Mazar, B. The Excavations in the Old City of Jerusalem Near the Temple Mount.Jerusalem: The Israel Exploration Society, 1971. Trans. Eretz-Israel 10 (1971) 


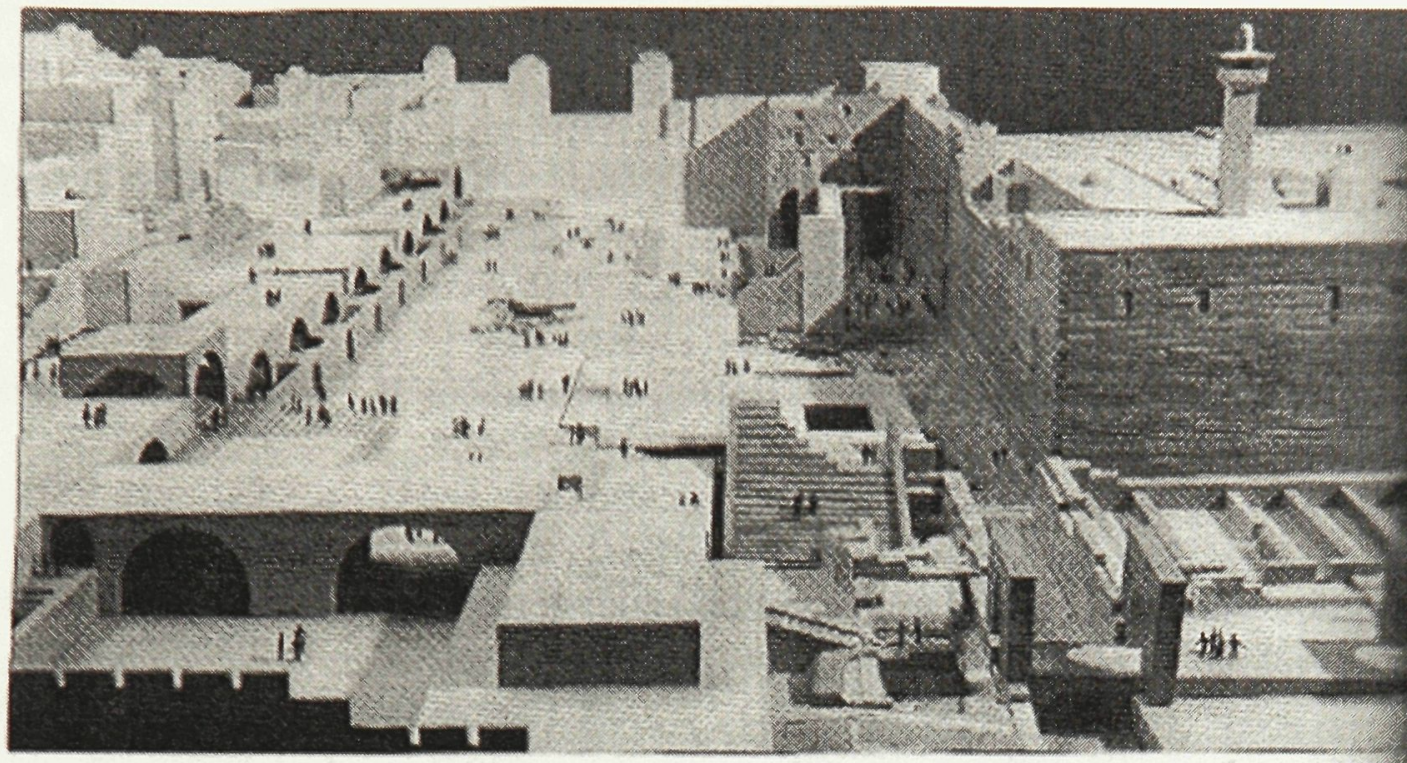

Western Wall - Detail of the reviscd model of the Western Wall Precinct. In the forceround are the gates to the Umayyad Palace and the pattial reconstruction of the Illcrodian suir the the temple. To the left is the Dung Gate entrance piazza connecting to the arcaded stret atop the Roman Cardo; to the upper left are the restored buildings on the clifr. (Sam Sweezy)

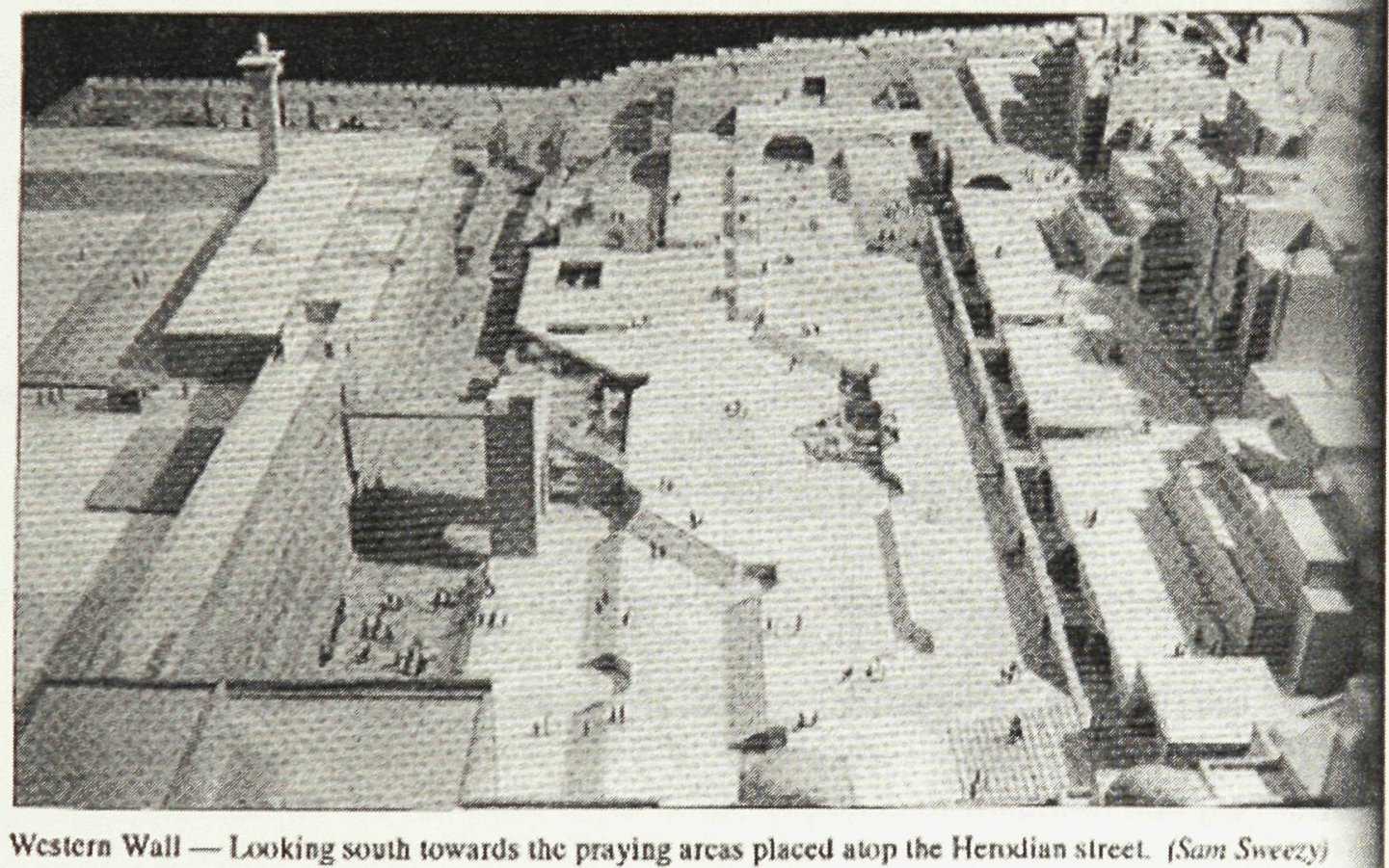

(above \& below) birds eye view's of the model showing the future development of the Western Wall. ${ }^{86}$ 


\section{Architecture \& Nation-Building}

Nation-building is a complex term. It is often associated with assumptions about the development of third-world societies and linked to the notion of de-colonization. Nationbuilding is often seen as a series of acts that can bring domestic peace, democracy and economic development. The media often portrays acts of nation-building as altruistic. This is often not the case. These acts, often politically rationalised using terms such as 'humanitarian intervention', or 'the responsibility to protect', are frequently motivated by political agendas and public propaganda.

Etzioni argues in his paper, A Self Restrained Approach to Nation-building By Foreign Powers, that nation building cannot be reduced to a single definition. One system of nation building cannot be applied to all cultures and developing nations alike.

Nation-building is defined by the reconciliation and unification of disparate ethnic groups, democratization, and economic reconstruction. It began as an act of communitybuilding that unified diverse ethnic groups within a state. "A major object of nationbuilding was to weld the disparate elements of the populace into a congruent whole by forging new identities at the national level at the expense of localism and particularistic identities" ${ }^{87}$ This process is seen to bring a sense of sovereignty through the establishment of a shared politic and new national identity.

$87 \mathrm{Pal}$ Kolsto, "Nation-building and social integration theory, in Pal Kolsto, ed., Nation-building and ethnic integration in post-Soviet societies: an investigation of Latvia and Kazakstan (Boulder, CO: Westview, 1999). 49 
Sovereignty is the ability for a government to implement the rule of law across its territorial boundaries. Nation-building tries to politically encourage stable government through the construction of a strong national identity. As nation-building forges new identities at the national level, it suppresses historic localism and particularistic identities. Strong localism can create instability in a homogeneous politic.

Economic development is often associated with nation-building. This is perhaps due to the belief that an improved economy often leads to a more stable and more functional government. And a more stable and more functional government in turn leads to more economic development. The two exist in a sort of symbiotic relationship.

Without relying on the use of force, nation-building must create a sense of shared loyalty and a belief in the common weal. This is often accomplished through a sense of shared identity, culture, and community. At the heart of these ideas lies the notion that the participants of the community understand that sacrifices must be made by individuals and interest groups for the larger good of a united nation.

The altering of established personal predispositions and relationships between people needing to form a seemingly homogenous community or nation, hinges on the ability to convince the participants of the benefits of such an alliance. Unfortunately, this is often done through violence, which in turn tends to produce animosity towards the new nation and its governance. 
"Nation-building is perhaps the most intrusive form of foreign intervention there is. It is the massive foreign regulation of the policy making of another country. The process usually entails the replacement or, in the case of a country in a state of anarchy, the creation of governmental institutions and a domestic political leadership that are more to the liking of the powers conducting the intervention. Since such profound interference tends to elicit resistance, the nation-building process typically requires a substantial military presence to impose the nationbuilding plan on the target country. $" 88$

To counter the aspect of creating a nation in the likes of its colonizer, a study of the history and culture of the nation in question has been proposed by some scholars. "Some scholars insist, in the tradition of the area studies school, that each situation is unique and that only by immersing oneself in the particular history and culture of each particular country can one establish what must be done there." 89 This school of thought is not as admired by foreign powers since it often requires greater cost, time, and understanding to transform a developing nation into a democratic capitalist state.

Nation-building fails when it does not work within the given cultural context and tries to impose foreign leadership and values over a short period of time.

88 Dempsey, Gary T. Fool's Errands: America's Recent Encounters with Nation-building. Mediterranean Quarterly. 12:1, 2001, 59 89 Etzioni, A. A Self-Restrained Approach to Nation-Building by Foreign Powers. Blackwell Publishing: International Affairs, Vol. 80, no. 1 1-17. January 2004 
"It vainly tries quickly to undo deeply ingrained cultural and psychological predispositions, strong emotional ties and (often) religious beliefs, as well as very powerful reward allocations by tribal chiefs or warlords, and equally quickly to substitute alien frameworks. A restrained approach would start by dealing with whomever is in power." 90

Western powers have commonly viewed Arabs as playing the role of victims who tend to blame others for their condition and demand that others compensate them accordingly, rather than take responsibility for their situation. ${ }^{91}$ This leads to a certain prejudice and lack of understanding as to why Arab nations are less disposed to western capitalism and neo-liberal democracy. This narrative tends to simplify complex issues of culture and history and categorizes Arabs as congenitally different from Westerners.

"The notion that cultural and psychological factors are at work is prejudiced only if one assumes that there are some inherent, genetic factors that make it impossible for some race or people to become democratic or developed, as some have written about the Arabs.",92

The full throttle approach to nation-building - defined by: the reconciliation and unification of disparate ethnic groups, democratization, and economic reconstruction, as

90 Etzioni, A. A Self-Restrained Approach to Nation-Building by Foreign Powers. Blackwell Publishing: International Affairs, Vol 80, no. 1 14. January 2004

91 Etzioni, A. A Self-Restrained Approach to Nation-Building by Foreign Powers. Blackwell Publishing: International Affairs, Vol 80, no. 1 1-17. January 2004

92 Stepan, Alfred. And Graeme B. Robertson. An Arab More than Muslim Electoral Gap. Journal of Democracy. 14:3, 2003, 29-44 
an act of community building that unifies diverse ethnic groups within an imagined nation - is perhaps not as easily accomplished as western political agencies would advocate. Robert Kaplan suggests that: "We shouldn't try to fix a whole society; rather, we should identify a few key elements in it, and fix them."93 Relative to the problems faced by a developing Palestinian nation, the belief that democracy will simply end the conflicts felt by generations is naïve. As Kaplan argues, identifying one key element to develop and invest time in is perhaps a more logical point of departure. As such, the development of a National Library of Palestine is a good starting point for developing an understanding of the complex issues at hand and beginning the long process of constructing a community based on a shared understanding of their values, beliefs, and cultures. 


\section{Architecture \& National Libraries}

Many authors and organizations have examined the task of creating guidelines for national libraries. For the purpose of this thesis, I will be focussing mainly on the "Guidelines for National Libraries" prepared by Guy Sylvestre for the International Federation of Library Associations and Institutions.

Although national libraries vary in size and scope from country to country, their aim is somewhat similar - that is, to preserve for posterity the written production of its people. "In general, it may be said that the national library of a country is the one responsible for collecting and conserving the whole of that country's book production for the benefit of future generations." ${ }^{94}$ Many national libraries seek to provide a wider range of literature to its citizens, rather than solely the production of its own people. "National libraries like the British Museum, the Bibliotheque Nationale in Paris and the Library of Congress, to name three of the largest and best known, offer not only comprehensive collections of the literature of the United Kingdom, France and the United States respectively, but also very large collections, both historic and current, of the literature of other countries." 95 These libraries pride themselves on their collections of past works as well as their ability to keep pace with the escalation of human knowledge.

Traditionally, the library building is thought to be a place of study, where scholars study the material works of the past in order to form and compose their own contributions for

94 National Libraries: Their Problems and Prospects. Symposium on National Libraries in Europe. Paris: UNESCO, 1960. 34 95 National Libraries: Their Problems and Prospects. Symposium on National Libraries in Europe. Paris: UNESCO, 1960. 21 
the generations to come. The national libraries' main objective is to provide its citizens, as well as citizens of other countries, essential information in all fields of study to facilitate basic research. This objective grows increasingly difficult under modern conditions as the size of basic works grows exponentially. "I suppose I have not been alone in wondering from time to time if the day of the comprehensive library as anything but a storehouse of older books and periodicals - a sort of museum - was perhaps over, and if the main burden of bibliographical and information work should not be handed over to small, highly organized libraries." 96

National libraries vary from other libraries in a country by the variety and volume of materials held and the national responsibility they bear within society.

"Another result of the leading position it occupies is that it sometimes has to act as a centralizing agency. This function, which is often exercised with respect to the general body of libraries, needs very careful handling. In certain countries and this point is made without passing judgement in any way - the position is that the general management of libraries is in the hands of the director of the national library himself.", 97

In Guidelines for National Libraries, Sylvestre outlines the guidelines for the development of national information systems. Special attention is given to the circumstances and needs of developing countries. As political, social and cultural

96 National Libraries: Their Problems and Prospects. Symposium on National Libraries in Europe. Paris: UNESCO, 1960. 23 97 National Libraries: Their Problems and Prospects. Symposium on National Libraries in Europe. Paris: UNESCO, 1960. 31 
traditions vary from country to country, no two national libraries perform the same function or provide the same services.

At the UNESCO symposium on national libraries held in Vienna in 1958 a definition of the tasks and obligations of national libraries was discussed. The discourse on national libraries showed the diversity of interests and viewpoints on the topic. "The tasks which every country should undertake both in its own interest and in order to retain its due place in the international network of cultural relations, "98 could not be agreed upon unanimously. However, the national library directors did agree that: "the conservation of contemporary manuscript documents of national importance is one of the functions of the national library" 99

In 1970, UNESCO adopted the following definition for national libraries:

"Libraries which, irrespective of their title, are responsible for acquiring and conserving copies of all significant publications published in the country and functioning as a 'deposit' library, whether by law or under other arrangements. They will also normally perform some of the following functions: produce a national bibliography; hold and keep up to date a large and representative collection of foreign literature, including books about the country; act as a national bibliographical information centre; compile union catalogues; publish the retrospective national bibliography. Libraries which may be called 'national' but

98 Sylvestre, Guy. Guidelines for National Libraries. Paris: UNESCO, 1987. 1

99 Sylvestre, Guy. Guidelines for National Libraries. Paris: UNESCO, 1987. 26 
whose functions do not correspond to the above definition should not be placed in the 'National Libraries' category.", 100

This definition excludes many libraries, especially those in developing countries that act on a national level. By way of contrast, in many countries, libraries, such as university libraries, although not officially designated as national libraries, perform the duties found in the UNESCO definition. Sylvestre advocates that national libraries cannot exist in isolation. "They must be a central element in a nation's information network; they must also be in a position to participate effectively in cooperative schemes at the international level, at least those of a regional scope from which the nation can most benefit."101 National libraries need to be developed as interdependent institutions in coordination with the regional and international community. Although technology is changing the nature and ways in which we approach information, national libraries must continue to perform the traditional role of ensuring the permanent preservation and availability of the nation's printed heritage. ${ }^{102}$

Libraries must reconcile the need to conserve collections for future generations with the need to serve the present reader. "They are at the crossroads of time and space; they link successive generations across decades and centuries in the sharing of the nation's literary heritage, and they build bridges between peoples across provincial and national 
borders." 103 As Sylvestre notes: "In recent years, usually after their access to political independence, many developing nations have established national libraries, as well as national archives, national museums, national theatres, etc. as visible manifestations of their nationhood." ${ }^{104}$ In light of the political significance of national libraries for developing nations, Sylvestre seeks to prepare government officials who are planning the creation of national libraries in countries where one does not yet exist.

National collections are to be more or less encyclopaedic in scope. In developing countries, where the cost of holding multiple collections of the same material is an issue, the national library will hold the most comprehensive collection of works. The collection of the national library must hold all works published within the country as well as by foreign authors who have published work on or pertaining to the country. The works of foreign authors should be translated into the native language of the country. The word "publication" is to be interpreted in the broadest sense and include non-book materials. "Ideally, the National Library collection of national literature should be as comprehensive as possible; it should include publications in all subjects, forms and languages." 105 Non-book materials may be held at satellite libraries. The collection held by the national library makes it possible to publish the national bibliography that needs to be submitted to the Universal bibliographic control (UBC), the Universal Availability of Publications (UAP), and the Universal Availability of Information (UAI),

103 Sylvestre, Guy. Guidelines for National Libraries. Paris: UNESCO, 1987. 5 104 Sylvestre, Guy. Guidelines for National Libraries. Paris: UNESCO, 1987. 5 105 Sylvestre, Guy. Guidelines for National Libraries. Paris: UNESCO, 1987. 9 
in order for the library to maintain its status as a national library. All publications must have the ability to be duplicated for the purpose of loan to institutions abroad. ${ }^{106}$ 


\section{The Alexandriana Library Past and Present}

Perhaps the first library to have been erected was the Alexandriana. Ptolemy I, a shrewd and courageous Macedonian chief and marshal of Alexander, invited the highest intellects of the age to his magnificent court. There, Ptolemy is said to have founded the Hellenic Renaissance. Ptolemy, a believer that armed force was necessary to maintain the state, knew that only the arts would immortalize his empire.

It was Ptolemy who gathered the many poets, philosophers, scientists, politicians, and men of letters of the Hellenic world. There among the gathered, a worldly traveller by the name of Demetrios, suggested to Ptolemy the creation of a museum and library. Thus, the first library, Alexandriana, was founded by Ptolemy and directed by Demetrios. The Alexandriana, a vast collection of literature, artefacts, and manuscripts, presumed to have lasted for over nine hundred years, now only exists in the imagination of text. ${ }^{107}$

Ptolemy I was succeeded by Ptolemy II in the early part of the third century B.C.E.

Ptolemy II, whose grand library was incorporated into his royal palace, set the precedent, incorporating the notion of library within palace and empire. One can only speculate as to the interior layout of the Ptolemy libraries as it was not until the second century that records of scale and layout began to surface.

107 Parsons, Edward Alexander. The Alexandrian Library: Glory of the Hellenic World. New York: Elsevier Publishing Company. 1967. 
Plutarch claims in his texts that the library of Alexander the Great contained 200,000 rolls. This library, linked to the temple through the Sanctuary of Athena, had a long view from its entrance down the valley to Aegean. The libraries of this period gave emphasis to the book or scroll. A large room where books and sculptures fit into the wall recesses emphasized the books by providing them with a symbolically important room type.

Book, sculpture and space merged to create architecture.

"The Library of Alexandria was one of the leading intellectual centers of the world. Having assembled a unique collection of scientific, philosophical and literary works, it was also a haven over the centuries for numerable authors who found their source of inspiration there...The Library, they built in the fourth century BC, became the world's first university with its college scholars including such famous names as Euclid, Erastosthenes, Heron and Archimedes, to name but a few. The great library, which also served as a publishing house, was built at the side of the museum. Anticipating our modern libraries in the way it was run, it had a catalogue of all the works it possessed - 700,000 of listed and classified manuscripts already in the third century BC - and enjoyed 'legal deposit rights', thereby, being entitled to make a copy of every book that entered the country."

In opposition to the Ptolemy type, a second tradition - a monastic development, gave greater emphasis to the reader than to the book. Perhaps linked to the monks of northern Europe, this tradition developed because the monks often used a small number of

$108 \square$ UNESCO. "UNESCO Bibliotheca Alexandrina website". [online]. Available from http://www.unesco.org/ (Accessed November 8, 2004) 
volumes for a great number of hours. This prolonged study, often very uncomfortable, lead to discussions of comfort, furniture and light. These early libraries, often containing small arched reading rooms where the reader had immediate access to a whole collection, became increasingly extinct as the numbers of readers and books increased. Libraries began to return to the more monumental Ptolemy type of library, where books now lined library walls and ceilings grew taller until ladders became awkward. The dichotomy between book monumentality and reader comfort is still the main issue in library typology. However, the relationship of libraries to power and knowledge has remained a constant throughout time. ${ }^{109}$

Mohamed Hosni Mubarak, President of the Government of the Arab Republic of Egypt, in co-operation with UNESCO and the financial support of the UNDP and other public and private sources, sought to revive the Ancient Library of Alexandria. The revival of the library has both renewed global connectivity with Egypt and improved its global cultural image.

The Library is a promotional device. While it provides a window on Egypt to the world through its promotion and status, it allows a window on the world to exist in Egypt. It is an invaluable information resource to support decision-making and broaden future horizons for the cultural, social and economic development of Egypt and the region. The library is a socio-political tool in creating cooperation between the north and the south of the Mediterranean Basin as well as between the east and the west.

109 Brawne, Michael. Libraries: Architecture and Equipment. New York: Praeger Publishers, 1970. 
The Bibliotheca Alexandrina stands as a testimony to a decisive moment in the history of human thought. It attempts to constitute a sum of knowledge through the writings of all the peoples. It is promoted today as a modern rendering of the original undertaking that sought to embrace the totality and diversity of human experience, thereby giving birth to a new spirit of critical inquiry, and to a heightened perception of knowledge as a collaborative process. ${ }^{110}$

On February 12,1990 in Aswan, Egypt, members of the International Honorary Commission including Heads of State and world dignitaries signed the Aswan Declaration for the Revival of the Ancient Library of Alexandria. The declaration clearly shows how the use of a library is used to connect the local heritage of Egypt with Egypt's international aspirations. The library is a tool for the cultural development of the nation. The library is seen as an institution that will be open to researchers from all over the world. The Bibliotheca Alexandrina is unique as it is the first national library to be designed and constructed with the help of the international community through the United Nations.

"We, the members of the International Commission for the revival of the Ancient Library of Alexandria, meeting at its inaugural session in Aswan in February 1990 under the chairmanship of Mrs. Susan Mubarak, pledge our wholehearted support and commitment to this end the appeal made by the Director-General of

$110 \square$ UNESCO. "UNESCO Bibliotheca Alexandrina website". [online]. Available from http://www.unesco.org/ (Accessed November 8, 2004). 
Unesco in 1987. We call upon all governments, international governmental and non-governmental organizations, public and private institutions, funding agencies, librarians and archivists, and the peoples of all countries to participate, by means of voluntary contributions of all kinds, in the efforts initiated by the Egyptian Government to revive the Library of Alexandria, to assemble and preserve its collections, to train the necessary staff and to ensure the Library's functioning. We call on scholars, writers and artists and all those whose task is to inform through the written and spoken word to help generate awareness of the international project for the revival of the Library of Alexandria and support for this historic venture. Finally, we urge all governments to donate to the Bibliotheca Alexandrina such works in their possession as will help to constitute and enhance the Library's collection, in recognition of the unique gift made by the Ancient Library of Alexandria to our common heritage." 111

The list of signatories shows the geographic area the libraries revival stretched across. The long list symbolises the contemporary importance of cultural knowledge with regard to identity and politics. The list includes: Susanne Agnelli, Senator, Secretary to Foreign Affairs (Italy); Queen Noor Al-Hussein of Jordan; Yahya Bin Mahfoudh Al-Mantheri, Minister of Education and Youth, (Sultanate of Oman); Sheikh Zayed Bin Sultan AlNahyan, President of the United Arab Emirates; Prince Turki Ibn Abdal-Aziz Al-Saud, Founder and President of the Arab Student Aid International (ASAI), (Saudi Arabia); Daniel Boorstin, Historian, Librarian of Congress Emeritus, (United States); Lord Briggs,

$111 \square$ UNESCO. "UNESCO Bibliotheca Alexandrina website". [online]. Available from http://www.unesco.org/ (Accessed November 8,2004$)$. 
Provost, Worcester College, Oxford, (United Kingdom); Gro Harlem Brundtland, Member of Parliament, (Norway); Princess Caroline de Monaco; Hans-Peter Geh, President of the International Federation of Library Associations and Institutions (IFLA), (Federal Republic of Germany); Abdul-Aziz Hussain, Adviser to His Highness the Amir of Kuweit; Dmitri Sergeevich Likhachev Academician, (USSR); Melina Mercouri, Member of the Parliament, (Greece); François Mitterand, President of the French Republic; Susan Mubarak, (Egypt); Queen Sofia of Spain; Ahmed Fathi Sorour, Minister of Education, Chairman of the General Organization of the Alexandria Library (GOAL), (Egypt); and Mr José Israel Vargas, Former Chair of the Executive Board of Unesco, (Brazil).

It was decided that the design of the new Bibliotheca Alexandrina would be chosen through an international architecture competition. Over 500 architectural offices from around the world submitted their design ideas in 1989. The winner, a Norwegian architectural firm named Snohetta, took first prize for their dramatic design.

"The new library is designed as a modem state-of-art translation of the old, adequate for crossing the frontiers and meeting the challenges of the 21 st. century. The design concept of the Bibliotheca Alexandrina is a simple circle representing the Egyptian sun, to symbolically illuminate the world and human civilization. The inclined roof allows indirect daylight and a clear view of the sea. The building is clad in Aswan granite engraved with calligraphic inscriptions representing the world civilizations. This wall symbolizes both the heritage of the 
region and a revival of cultural radiance to reach out to all corners of the universe. The library is 525 feet (160 meters) in diameter and 750,000 square feet $(70,000$ square meters) in area. The main reading hall is located in half the building in a large open amphitheater, accessible through a central loaning station and smaller satellite information desks. The reading room seats 2000 persons and is flexible in its accommodation of current and future technologies. The US\$150 million project is designed to accommodate 4 to 8 million volumes." 112

A consortium was arranged in October 1993 for the construction of the library. Hamza Associates, a local Construction Management team, was selected by Snohetta to build the library. Hamza Associates provided the detail design and engineering services throughout the planning period. They also acted as the resident engineers during the construction. Thorsen, along with his associates at Snohetta, American Craig Dykers and Austrian Christoph Kapeller, dug into the depths of Egyptian history to create a modern interpretation of the famed library.

“We did quite a bit of historical research,' said Thorsen, who still looks like he is in his 30 's, more than a decade on. 'There are so many myths connected to the Library of Alexandria and some varying opinions about how things happened. We had to think about a way to deal with the history and how to incorporate that into the design.' To execute their vision for Bibliotheca Alexandrina, the Snøhetta team enlisted the Egyptian engineering consultancy firm Hamza Associates to

112 El Sahn, Marwa. World Library and Information Congress: 69th IFLA General Conference and Council. August 2003, Berlin. 1- 
turn their five conceptual sketches into reality. Dr. Mamdouh Hamza, Chairman of the planning, architecture and engineering firm, was impressed by what he called Snøhetta's 'genius design'.,"113

Foundation excavation work began in January 1995. The new Bibliotheca Alexandrina had its official inauguration ceremony on October $16^{\text {th }} 2002$ and is now open to the public. Snohetta describes the finished architectural product on their web site.

"The most prominent characteristic of the new library is its circular, tilting form; rising from the ground to reveal massive stone walls carved with alphabetic inscriptions. Covered by a light roof allowing the building to open toward the Mediterranean sea. Within the interior a great room, similar to traditional libraries of previous centuries, opens up revealing the building's form into the reading space. The reading space is developed in an original manner along terraces which conceal the limited access books, providing a new standard in library planning. Also housed within the building are other cultural facilities and a small school; to the exterior is a small planetarium for the general public. Lastly the building is surrounded by a reflecting pool and large public plaza, connecting it to the city as a gathering place for contemplation and debate"114

113 Egyptian State Information Service. Bibliotheca Alexandrina: The Norwegian-Egyptian Connection. October 20, 2004. [Online], Available from http://www.sis.gov.eg (Accessed November 8, 2004)

114 Snohetta Architecture. Project Description: Bibliotheca Alexandrina. [online]. Available from http://www.snoarc.no/ (Accessed November 5, 2004) 

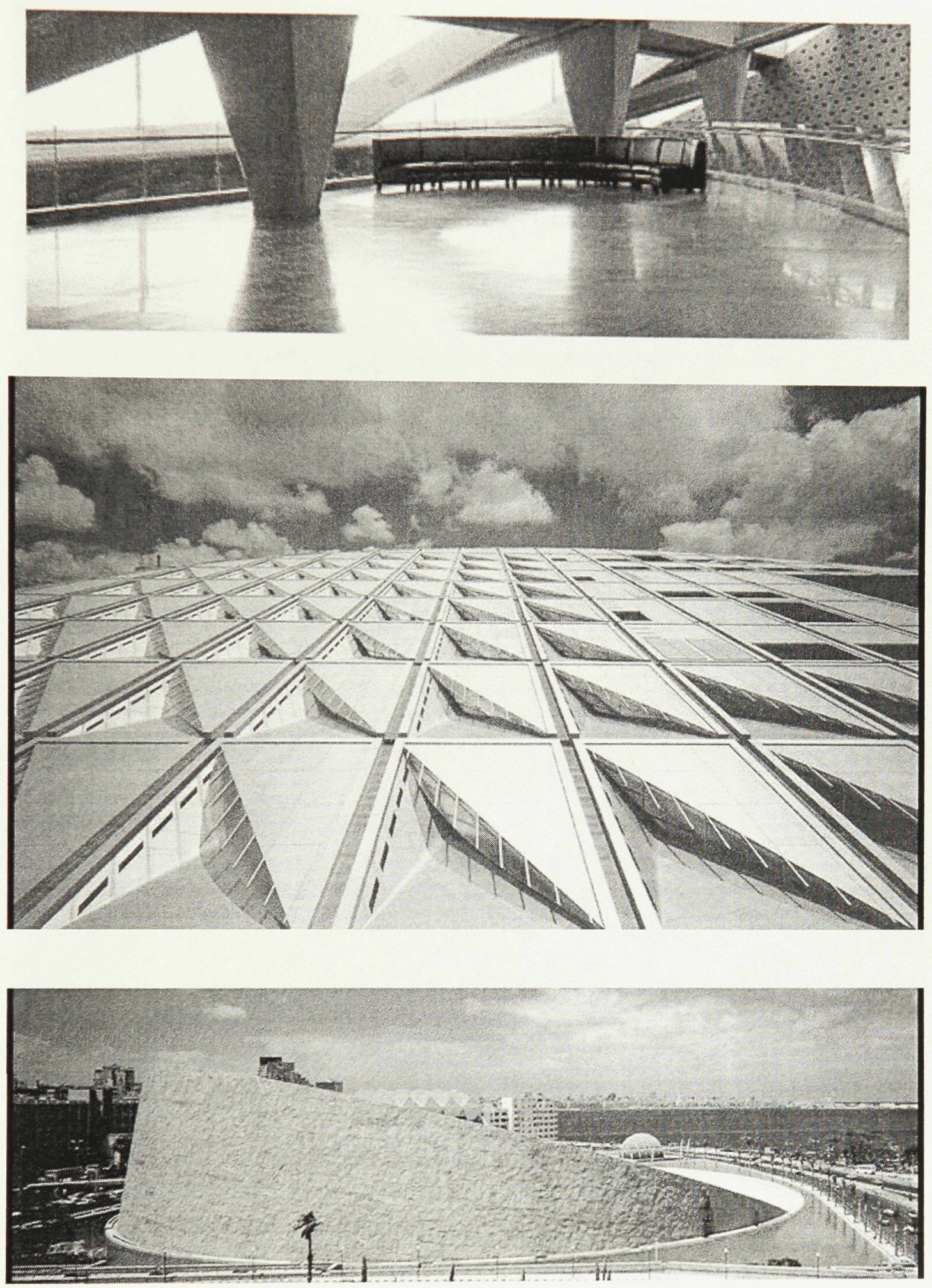

Pictures of the Bibliotheca Alexandrina. (above) Interior view of the sloped roof. (middle) Exterior view of the sloped roof. (bottom) birdseye view of the semicircular stone wall. ${ }^{115}$

115 Snohetta Architecture. Project Description: Bibliotheca Alexandrina. [online]. Available from http://www.snoarc.no/ (Accessed November 5, 2004) 

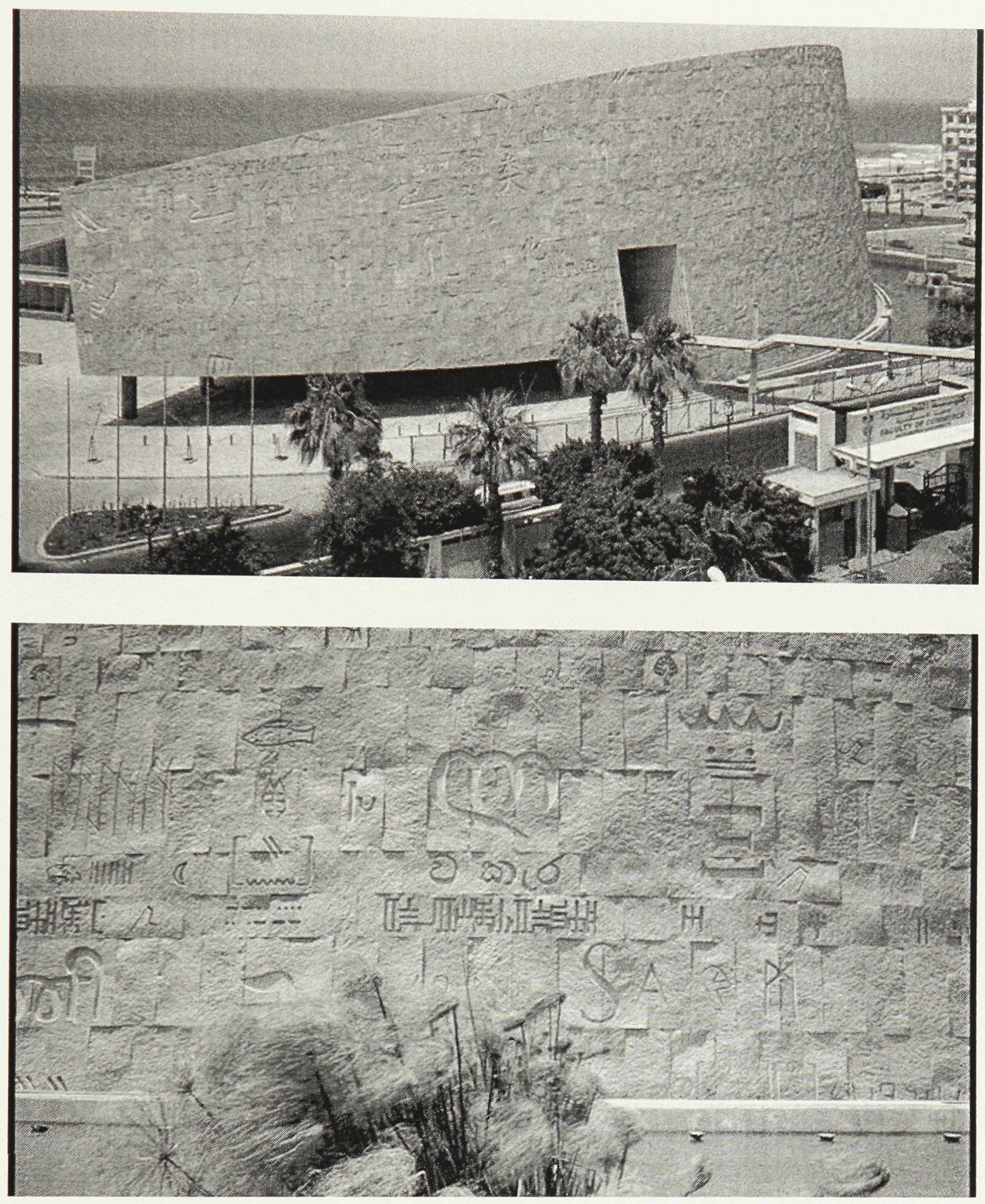

(above) Birdseye view of the semicircular stonewall \& entrance bridge. (below) Up close view of text engraved on semicircular stonewall. ${ }^{116}$

116 Snohetta Architecture. Project Description: Bibliotheca Alexandrina. [online]. Available from http://www.snoarc.no/ (Accessed November 5, 2004) 

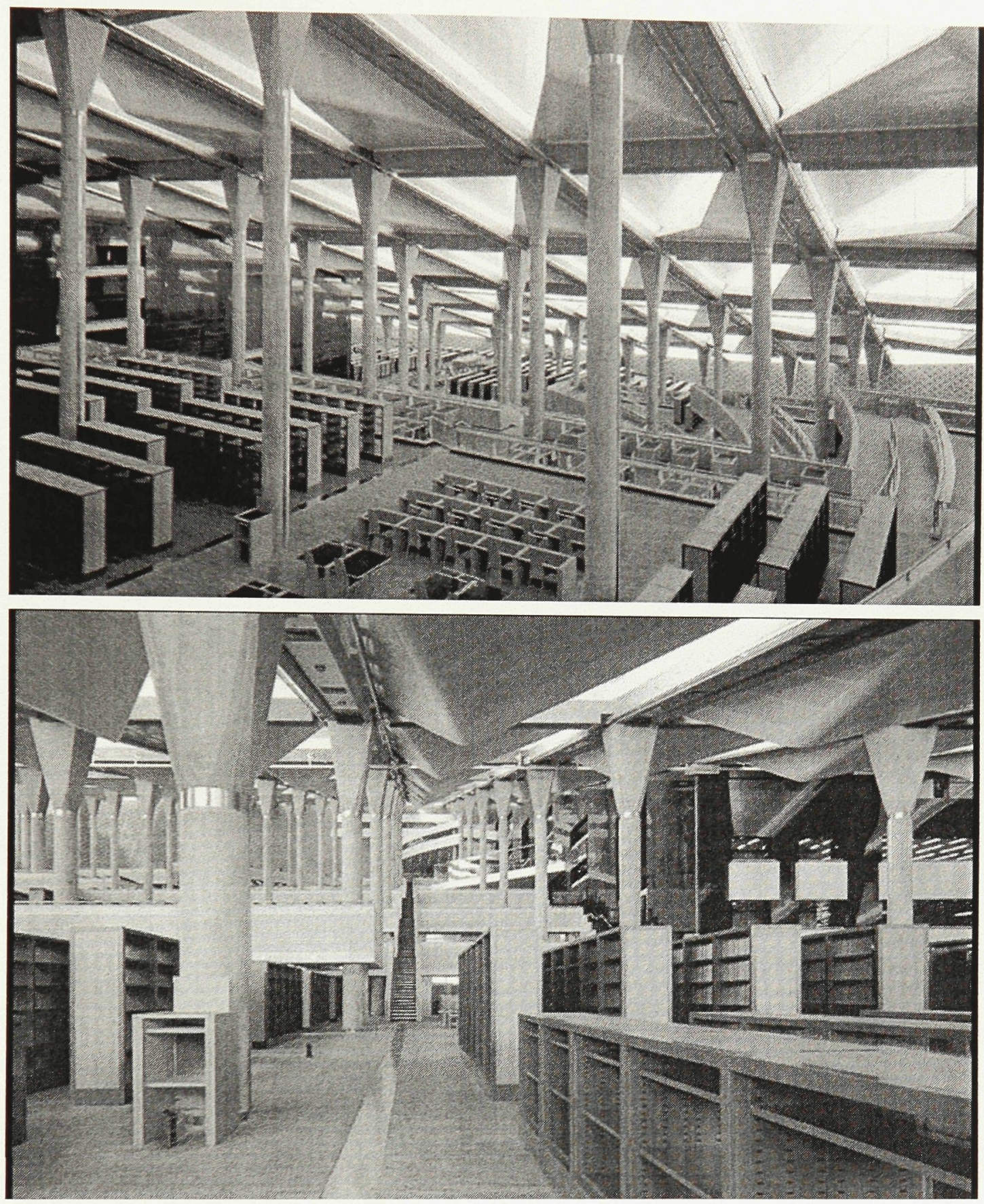

(above \& below) Interior views of the cascading book shelves. ${ }^{117}$

117 Snohetta Architecture. Project Description: Bibliotheca Alexandrina. [online]. Available from http://www.snoarc.no/ (Accessed November 5, 2004) 

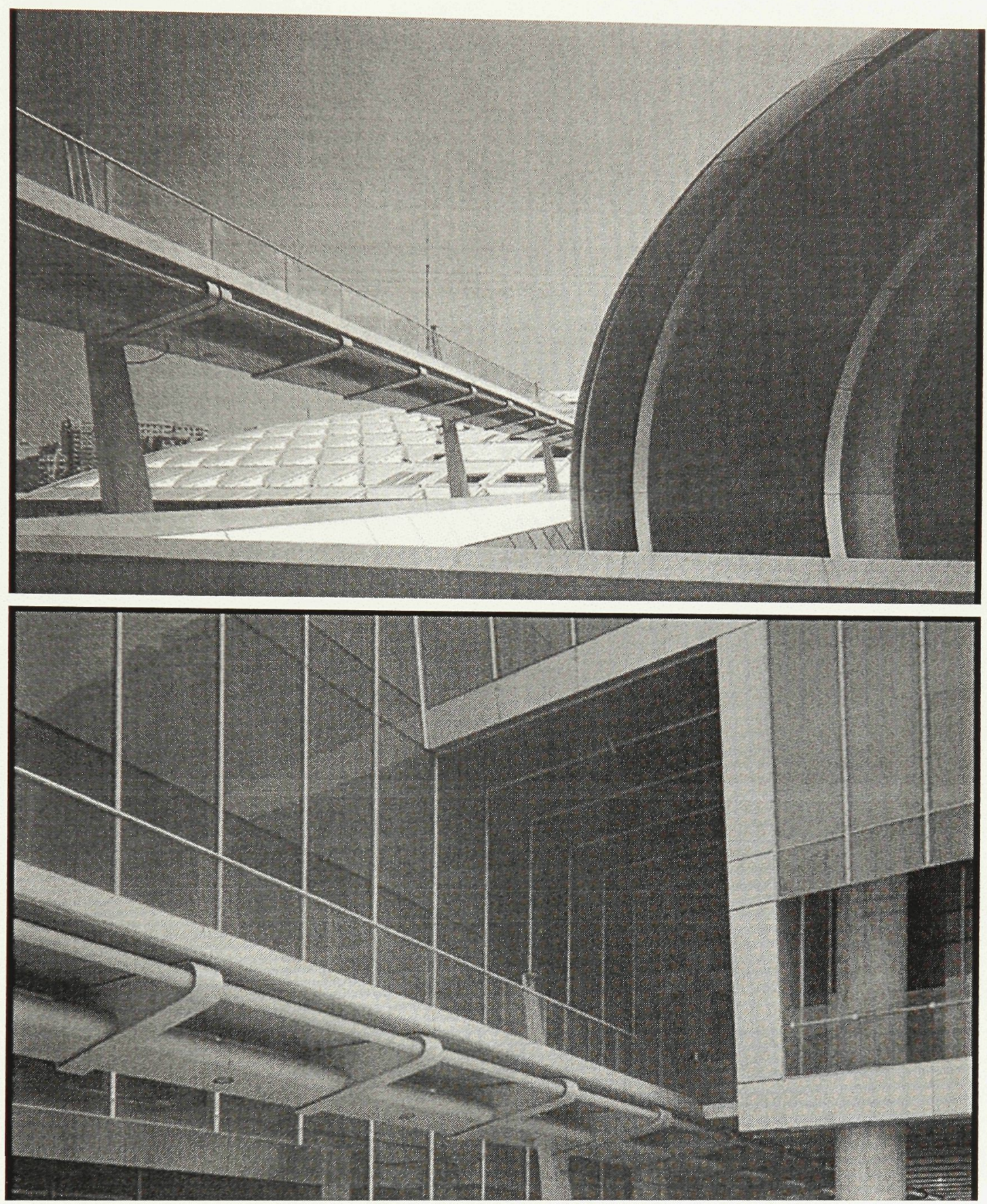

(above) Exterior view of the small public planetarium. (below) entrance bridge emerges from the other side of the library. ${ }^{118}$

118 Snohetta Architecture. Project Description: Bibliotheca Alexandrina. [online]. Available from http://www.snoarc.no/ (Accessed November 5, 2004) 

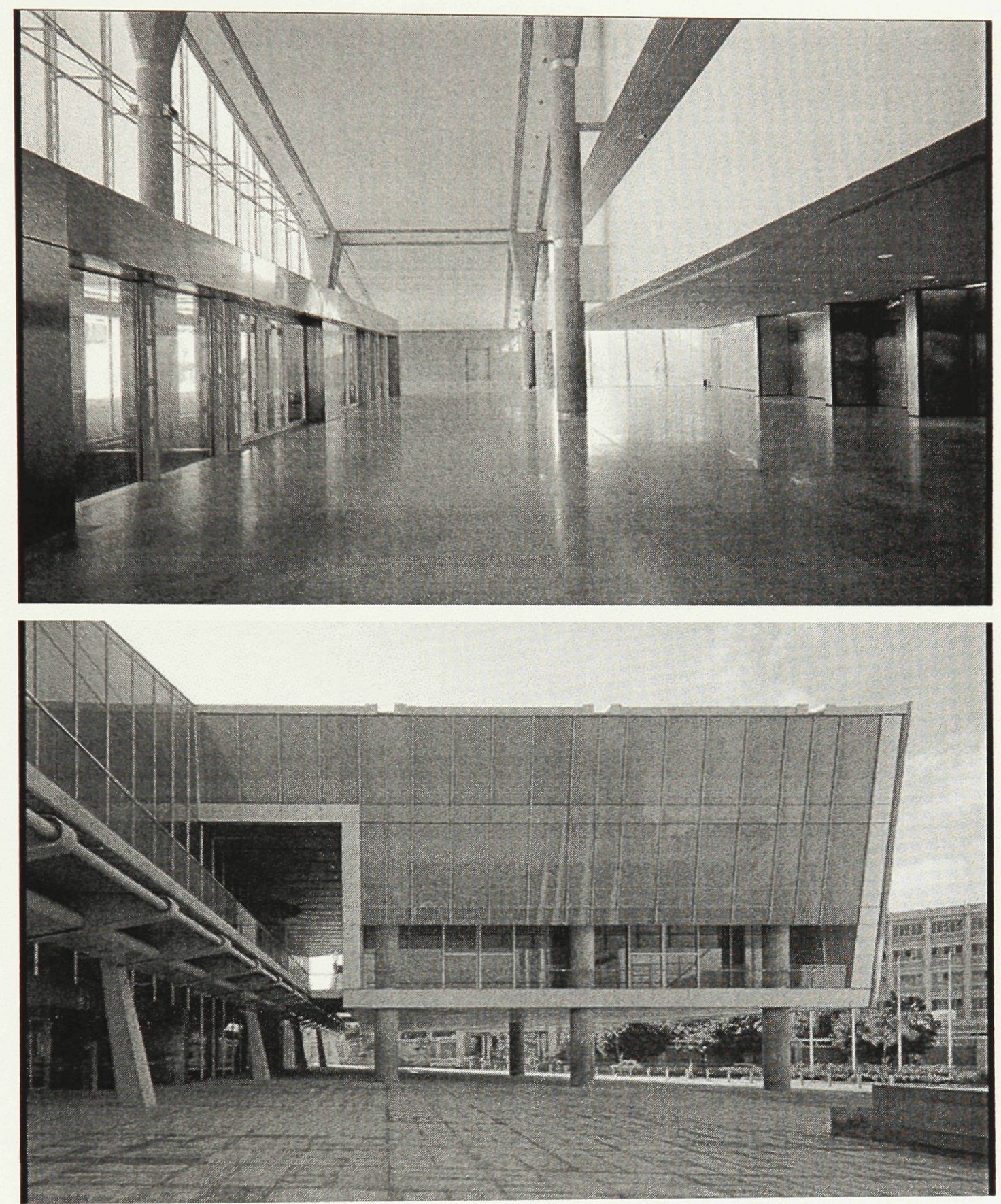

(above) Interior view of cultural exhibition and gathering space. (below) Exterior view of entrance bridge from interior courtyard. ${ }^{119}$

119 Snohetta Architecture. Project Description: Bibliotheca Alexandrina. [online]. Available from http://www.snoarc.no/ (Accessed November 5, 2004) 

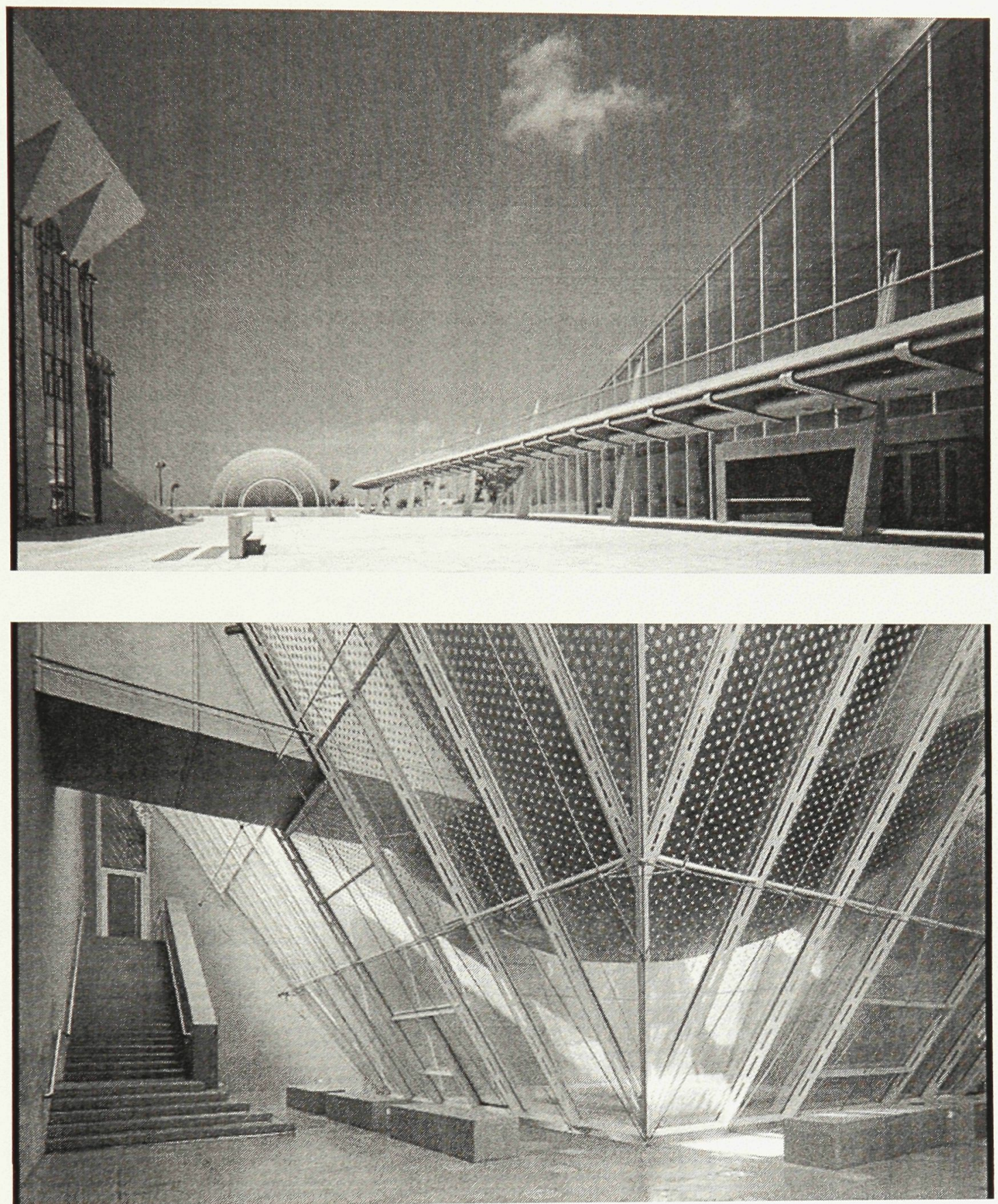

(above) Exterior view towards the sea. (Below) Interior view of small planetarium. ${ }^{120}$

120 Snohetta Architecture. Project Description: Bibliotheca Alexandrina. [online]. Available from http://www.snoarc.no/ (Accessed November 5, 2004) 


\section{Architecture \& Place}

Aldo Rossi, in his book The Architecture of the City, examines the complexity of the city and its relation to architectural artefacts. Rossi notes, in his chapter Politics as Choice, that politics constitutes the decisive moment in the construction of the city, the architecture of urban artefacts.

"Politics constitutes the problem of choices. Who ultimately chooses the image of a city if not the city itself - and always and only through its political institutions. To say that this choice is indifferent is a banal simplification of the problem. It is not indifferent: Athens, Rome, and Paris are the form of their politics, the signs of their collective will." ${ }^{121}$

Rossi's assertion that the image of a city is the sign of its collective will and the form of its politics, is an assumption that can lead to the many misleading architectural narratives found in places where the collective will of a certain ethnography does not have the authority to shape their own image. In these areas, such as Palestine, the image or politic is represented by the dominant narrator who can suppress one image for another.

In Lay of the Land, Stephen Zacks describes the changing demographics in the West Bank. Zacks reveals a troubling phenomenon: urban sprawl as human-rights abuse. Zacks examines Eyal Weizman's color-coded map of Palestinian and Israeli habitations 
in the territory occupied by Israel since 1967. "It's a graphic illustration of a struggle waged as much in bricks and mortar as with bombs and machine guns."

As Zacks notes "From the country's 1948 inception, the Israeli program was a straightforward one: to build a Jewish state in an area where the vast majority of the population was not Jewish; and architecture and planning, in tandem with the advance of soldiers and tanks, played a central role." ${ }^{123}$ After the Oslo Peace Accords in 1993, the speed of demolition and construction in the West Bank increased, and it became evident that the war of the future had more to do with planning and design than it did with soldiers and tanks.

Weizman and his partner Rafi Segal, who were preparing an exhibit for the Venice Biennale and World Congress of Architecture, became the key authorities on the planning and colonization of the West Bank. Weizman explains the geopolitical nature of the Jewish settlements, the Israeli agenda being to cut the territory into a patchwork of isolated enclaves.

"It was very clearly stated in the master plans for the whole West Bank that you need to bisect the area, to put wedges in between the Palestinian cities to shrink their economy and create forced emigration. The other thing was not to allow the formation of a Palestinian state, not to allow contiguity between the enclaves." 124

122 Zacks, Stephen. Metropolis "Lay of the Land". New York: Bellerophon Publications, February 2003. 83 123 Zacks, Stephen. Metropolis "Lay of the Land". New York: Bellerophon Publications, February 2003. 83 124 Zacks, Stephen. Metropolis "Lay of the Land". New York: Bellerophon Publications, February 2003. 85 
The colonization of the area is highly accelerated by modern construction techniques and virtually every hilltop has a modern Israeli settlement, leaving the Palestinian refugee camps littering the valleys below.

"There was a careful process of strategic design that pushed the civilian population into the occupied territories to achieve geopolitical objectives." ${ }^{125}$ Through the use of economic incentives such as no-money-down mortgages, preferred interest rates, and a cost of about half that of a home within Israel, a new Israeli immigrant is quickly swayed into purchasing land outside the state lines.

The division of land as described by Weizman as the "politics of verticality" cuts the land vertically giving the hilltops to the Israelis and leaving the valleys between them to the displaced Palestinians. These valleys, blocked at regular intervals by Israeli roadblocks, make the journey to and from work an arduous task.

"Even as terrorists bombs explode across the valley, ground-breaking for new colonies in the West Bank is announced with great antiterrorist fanfare. Tanks and bulldozers roll in and knock down buildings and dig up orchards and olive groves; armoured personnel carriers unload men, guns and supplies. A security post is established; soon a new city will flourish. The local villagers are employed to build the new city or have to leave to find work, becoming refugees. 
As the city engulfs nearby Arab villages, all entrances and exits are controlled. From time to time opposition groups fight against American made tanks and helicopters with hand-me-down rifles; there's sniper fire along the suburban highway. But for the most part the gates of the new community are well protected. Housing is cheap, views are scenic, and a local bus takes you on a smooth ride to the nearest metropolis each day for work." 126

Weizman and his partner Rafi Segal, who won an architectural competition organized by the Israel Association of United Architects, were chosen to prepare an exhibition of Israeli architecture for the 2002 Berlin Union Internationale des Architectes. Their aim was to examine the role of Israeli architecture in the Middle East conflict. The Israel Association of United Architects quickly decided to cut funding for the project and later decided to prevent the manuscript's distribution and destroy the five thousand copies already printed. A second edition of the censored catalogue by David Tartakover, $\underline{\mathrm{A}}$ Civilian Occupation: The Politics of Israeli Architecture, was released in 2003. Sharon Rotbard, in the preface to the book, advocates the need for architecture to be examined, not as a mere professional activity, but as a political act.

"Since the shaping of the physical reality takes place on different scales, such as the political, the urban and the architectural, architecture is no less 'political' than 
'urban'. The very act of censoring the catalogue was proof that the denial of the political dimension of architecture is in itself a clear political statement.",127

The geopolitical relationship between the organization of space and the redistribution of population is manifested throughout the landscape.

"The relationship between the landscape and the Israeli-Palestinian conflict is symbiotic. The terrain dictates the nature, intensity and focal points of confrontation, while the conflict itself is manifested most clearly in the processes of transformation, adaptation, construction and obliteration of the landscape and the built environment." 128

Architecture and planning is used by the Israeli state as a strategic weapon serving its political agendas through the construction of roads, hilltop settlements, development towns and garden suburbs. The relationship between architecture and politics presented by Weizman and Segal establishes the architect as a political player. "Architecture was presented as a political issue, and furthermore as the material product of politics itself."129 Buildings are not usually associated with acts of war, perhaps due to the fact that buildings are created by architects and are not the consequence of military planning, but the result of a series of private commissions. However, as Weizman and Segal point out:

127 Weizman, Eyal. \& Rafi Segal. A Civilian Occupation "The Politics of Isrueli Architecture". Israel: Babel, 2003. 15-16 128 Weizman, Eyal. \& Rafi Segal. A Civilian Occupation "The Politics of Israeli Architecture". Israel: Babel, 2003. 19 129 Weizman, Eyal. \& Rafi Segal. A Civilian Occupation "The Politics of Israeli Architecture". Israel: Babel, 2003. 20 
"Buildings matter, just like the tank, the gun and the bulldozer, is a weapon with which human rights are violated and crimes are being committed." ${ }^{130}$ Buildings in Israel are inherently political. Whether they aim to divide the land, create an identity or expand the nation, they are often linked to some greater political agenda. As Sharon Rotbard says, the building of a sovereign state for the Jewish people is "an industry for the fabrication of political realities." 131

If we examine the narrative created by the architecture referred to by Weizman and Segal, one can make the following observations: The Israeli settlements occupy the high ground, creating a visual segregation between the Israelis who control the landscape and the Palestinians who are imprisoned within the valleys. "The settlements are not only places of residence, but create a large-scale network of 'civilian fortification', generating tactical territorial surveillance in the state's regional strategic defence plan." ${ }^{132}$ The Israeli suburban house is set against the Palestinian refugee dwelling. The suburban house symbolises modernity, stability, community and safety and looks down on the displaced Palestinian dwellings that appear like moving crates. The Palestinian dwellings amplify the notion of the nomadic Palestinian who is living within a shipping container and awaiting deportation. The hilltop fortresses are not fortified with walls around them like the early crusader forts, but instead the Palestinians are fenced in. This creates a sense that it is not the Israelis who are invading the Palestinian territory. Rather, the Israelis are only imprisoning the criminals that happened to have been on their land.

130 Weizman, Eyal. \& Rafi Segal. A Civilian Occupation "The Politics of Israeli Architecture". Israel: Babel, 2003. 25
131 Weizman, Eyal. \& Rafi Segal. A Civilian Occupation "The Politics of Israeli Architecture". Israel: Babel, 2003. 41
132 Weizman, Eyal. \& Rafi Segal. A Civilian Occupation "The Politics of Israeli Architecture". Israel: Babel, 2003. 85 
Weizman and Segal go on to describe how settlements often use religious stories to justify their creation and help to sell their position. "No longer seen as a resource to be agriculturally or industrially cultivated, the landscape, imbued with imaginary religious signifiers, established the link that helped re-create and re-enact religious-national myths that displace (on the very same land) ancient with modern time." 133 Often, the brochures for such settlements mention "pastoral, biblical landscape", while the Palestinians exist in a sort of frozen state as part of the biblical landscape, like the presence of livestock grazing in open pasture.

Gidon Levy narrates the disturbing story of neighbouring communities in his article The Lowest Points in Israel. Here Levy talks about living in hatred and fear. "The settlements are almost always up there, scarring the landscape, dominating the plateau, challenging, provoking, picking a fight. Down in the flatlands live the 'natives' - the Palestinians down below - this is the essence of the story." ${ }^{134}$ Levy describes the daily fears of the armed settlers and their rituals that are plagued by the uncertainty of the acts of their government.

"Behind the barbed-wire fence (and the latest addition: electrified fences - yes, electrified fences, with all their connotations), behind roadblocks manned by armed soldiers and security officers, behind floodlights and iron gates, behind sandbags and concrete blocks, in vehicles armoured against stones - and lately

133 Weizman, Eyal. \& Rafi Segal. A Civilian Occupation "The Politics of Israeli Architecture”. Israel: Babel, 2003. 87 134 Weizman, Eyal. \& Rafi Segal. A Civilian Occupation "The Politics of Israeli Architecture". Israel: Babel, 2003. 168 
against gunfire - driven by civilians who are almost always armed, and in buses escorted by jeeps and troops of soldiers, the settlers go about their business in a land that is not their own, filled with people who don't want them there. The children go to ballet and clarinet classes accompanied by armed guards, and the elderly drive to their weekly game of bridge with a rifle stuck between their knees. More than a few of them have already been killed; many more of us await our death because of the settlers' whims." 135

Levy questions why Israel has chosen to overlook such things as international law, "that explicitly prohibits the transfer of civilian population into occupied territory - an act that is considered a war crime by the Fourth Geneva Convention." 136

Levy asks why, out of the 200,000 settlers in the occupied territories, there is no one who has stood up and said that what they are doing is wrong. He asks, how day after day, settlers see from their living room window, in the valley below, such immense suffering and remain indifferent.

All that is left of Palestinian architecture are those built artefacts that strengthen the Israeli politically-motivated image that represents the Palestinian people as nothing more than a criminal population awaiting deportation. Anything other than this, any remnant of cultural heritage, is uprooted in fear that one day someone will return and claim to have existed.

135 Weizman, Eyal. \& Rafi Segal. A Civilian Occupation "The Politics of Israeli Architecture". Israel: Babel, 2003. 168 136 Weizman, Eyal. \& Rafi Segal. A Civilian Occupation "The Politics of Israeli Architecture". Israel: Babel, 2003. 169 

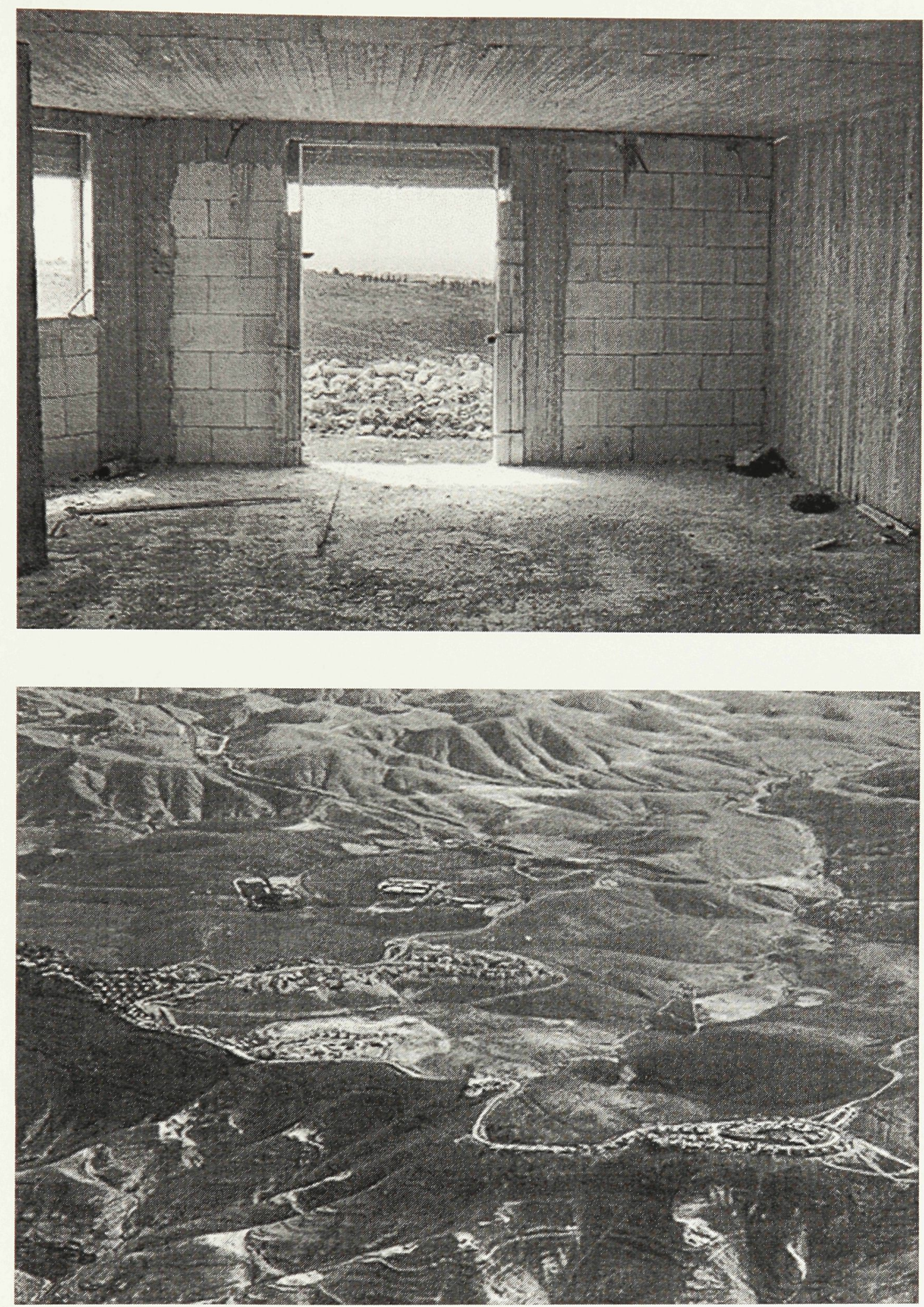

(above) A view from the interior of a settlement under construction at Na'ale on the outskirts of Jerusalem, provides clear views of the valley below, as well as of another settlement on a distant hilltop. (below) Most settlement towns, like Kfar Edummim and Nofei in the region of Jericho are sited on high ground. The settlements form a chain of links from one settlement to another ${ }^{137}$ 

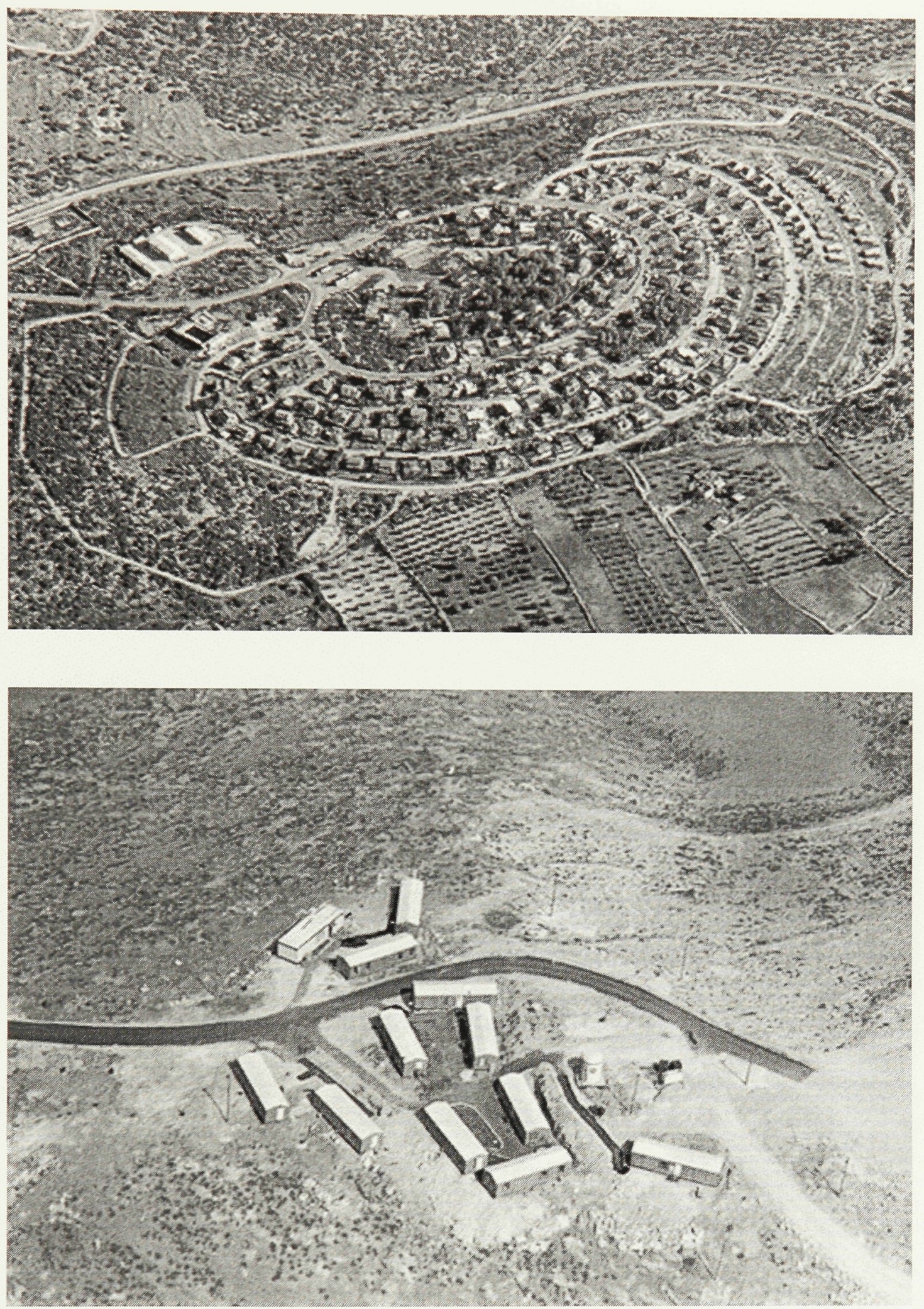

(above) The colony in the West Bank near Jenin is planned to optimize surveillance of the surrounding region. Each house is a link in the settlements protective wall. (below) A new settlement begins construction near Ramallah. ${ }^{138}$ 

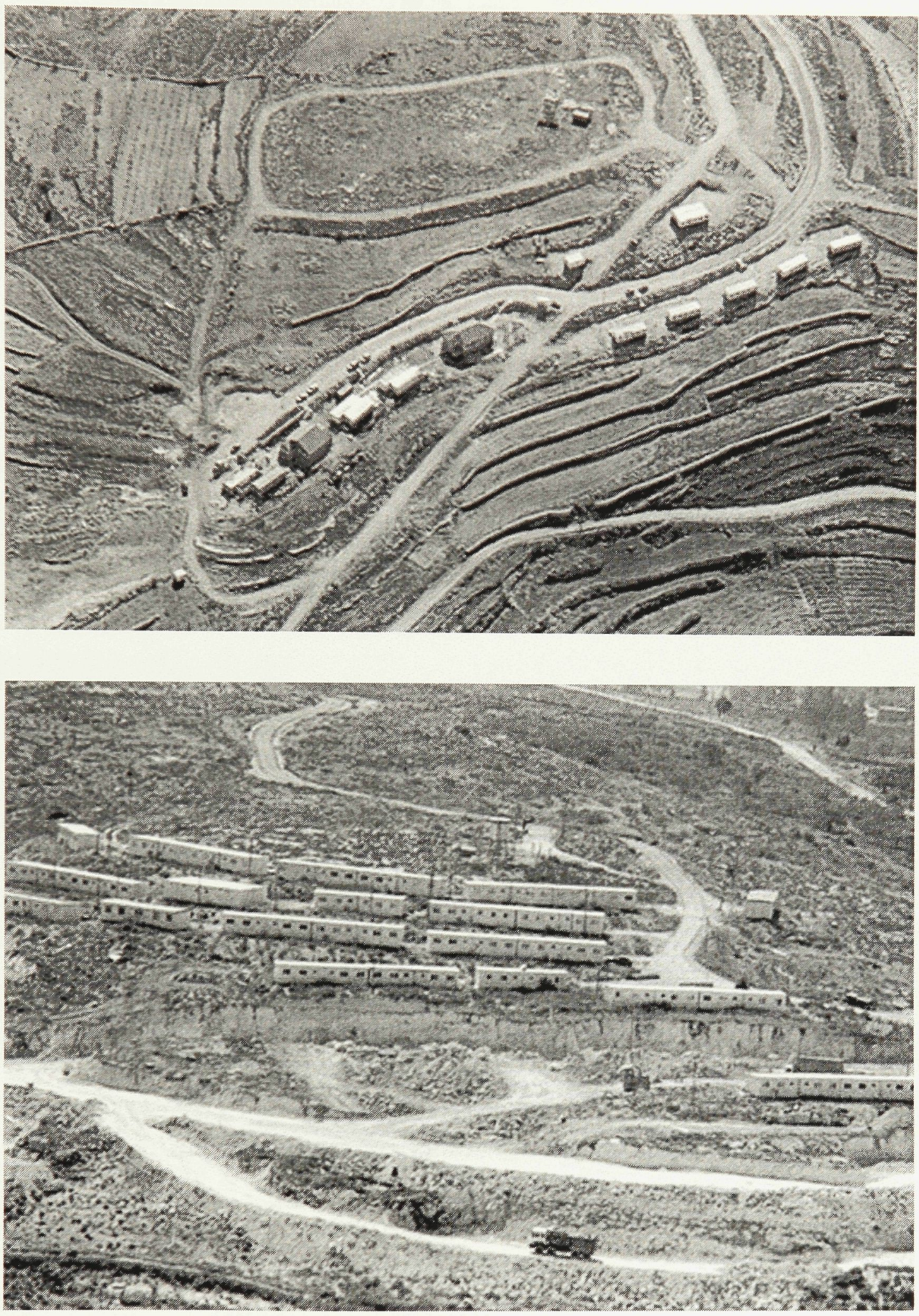

(above and below) More new settlements claim the hill tops near Ramallah. Prefabricated units are put in place while the construction of more permanent suburban style dwellings are constructed. ${ }^{139}$ 


\section{The Mukataa and Yasser Arafat}

The Mukataa, the site of the Palestinian headquarters, was the prison of the mediamarginalized Palestinian leader Yasser Arafat until his death in November 2004. This compound, the current command center of the Palestinian Authority, is the size of several city blocks in what used to be a prosperous neighbourhood in Ramallah. The building was, first, the site of an army base in support of the British occupation and, then, a Jordanian administrative centre until the occupation of Ramallah in 1967 by Israeli forces. Due to attacks by Israeli forces, a large number of the buildings have been destroyed. Arafat, unable to leave the confines of the Mukataa, was seen to represent the Palestinian experience throughout occupied Palestine. The Israeli occupation has made most Palestinians prisoners within there own towns, unable to penetrate the many Israeli road blocks and check points.

"Of the 1.3 million residents of Gaza, roughly 19,000 have permits to work in Israel, and another 6,000 are permitted to work at an industrial park at the border crossing; none of these can be certain that, on any given morning, they will be allowed out by Israeli soldiers."140

In an interview, published in the New York Times Magazine, Mahdi Abdul Hadi, the head of Passia, an important Palestinian policy group, stated that: "Arafat is old and tired, 
but he is still the glue that binds the Palestinian people together, the symbol of our national pride" 141

Arafat grew old and weak in isolation. Many believed he had become nostalgic and had 'lost his legitimacy' as he was no longer a key figure in the peace negotiations.

Regardless of how marginalized Arafat became in his last years, he remained revered by the Palestinians as an icon of the Palestinian struggle. A man who was a welcome guest at the White House during the Clinton administration and hailed as a peacemaker between 1994 and 1999, receiving the Noble prize for his willingness to negotiate with the Israeli American administration, Arafat was still viewed by Palestinians as the personification of Palestinian national aspirations. Arafat continued to meet daily with Palestinian notables, foreign diplomats, religious delegations, and Arab journalists, in the last two remaining structures of the Mukataa until the very end.

There is a need for a common narrative to be established and a legacy to be handed down. Media is the weapon by which this war is being fought. Palestinians must realize the importance of information in an age of myth. In the words of Kojin Karatani: “....it is only reason itself that can deconstruct reason." ${ }^{142}$ Only through a rigorous cataloguing of events, artefacts, and history shall the truth be translated for future generations.

141 Rieff, David. The New York Times Magazine: Arafat in His Labyrinth. "Arafat Among the Ruins". April 25, 2004. 55 142 Karatani, Kojin. Architecture as Metaphor: Language, Number, Money. Trans. Sabu Kohso. Ed. Michael Speaks. Cambridge, MA.: MIT Press, 1995. 4 - 57. 
In Libraries for Peace: Arafat Sees Education as the Key to Development, by Ron

Chepesiuk, Arafat is optimistic that a Palestinian state will eventually be declared. He also sees, a national Palestinian library as the key to Palestinian development.

Chepesiuk, a professor and Head of Special Collections at Winthrop University in Rock Hill, SC, reports on the conditions of Palestinian libraries in November of 1997.

Chepesiuk received a letter from Dr. Fouad El-Harazin, President of the Palestinian

National Authority and US-based Gaza Governate Peace on Earth International

Foundation, indicating that the Gaza Strip was in desperate need of books and periodicals, because none have been added to their collections for the past three decades.

In his report, Chepesiuk suggests that the Palestinian National Authority is planning the construction of a much-needed national library, estimated to cost approximately 28 million dollars. The Palestinian National Authority believes this national library to be, culturally, of the highest priority. Arafat, when asked about the importance of the national library during a period of Palestinian crisis, replied:

“A National Library can serve as a symbol of cultural pride. It's important because it is the institution that preserves the record of the people. It will also serve as a foundation for the growth of our national library system." 143

Chepesiuk goes on to describe the devastating conditions of libraries he visited in Gaza that year. He describes reading rooms overcramped with students looking at sparse

143 Chepesiuk, Ron. Libraries for Peace: Arafat sees education as the key to development. February 1998. http://www.towardfreedom.com/1998/feb98/librar.htm 
collections of books, full of outdated references, and few periodicals. The only journals found in elementary institutions such as "The Journal of Geriatric Dermatology", and "The Journal of Neurosurgery", had nothing to do with the curriculum. The library at Alazhar University, which has 11,000 students, has just 1500 books, no budgets, and zero periodicals. 'It's really frustrating', states Dr. Awni El Kayzoun, an Assistant Professor of English at the university. 

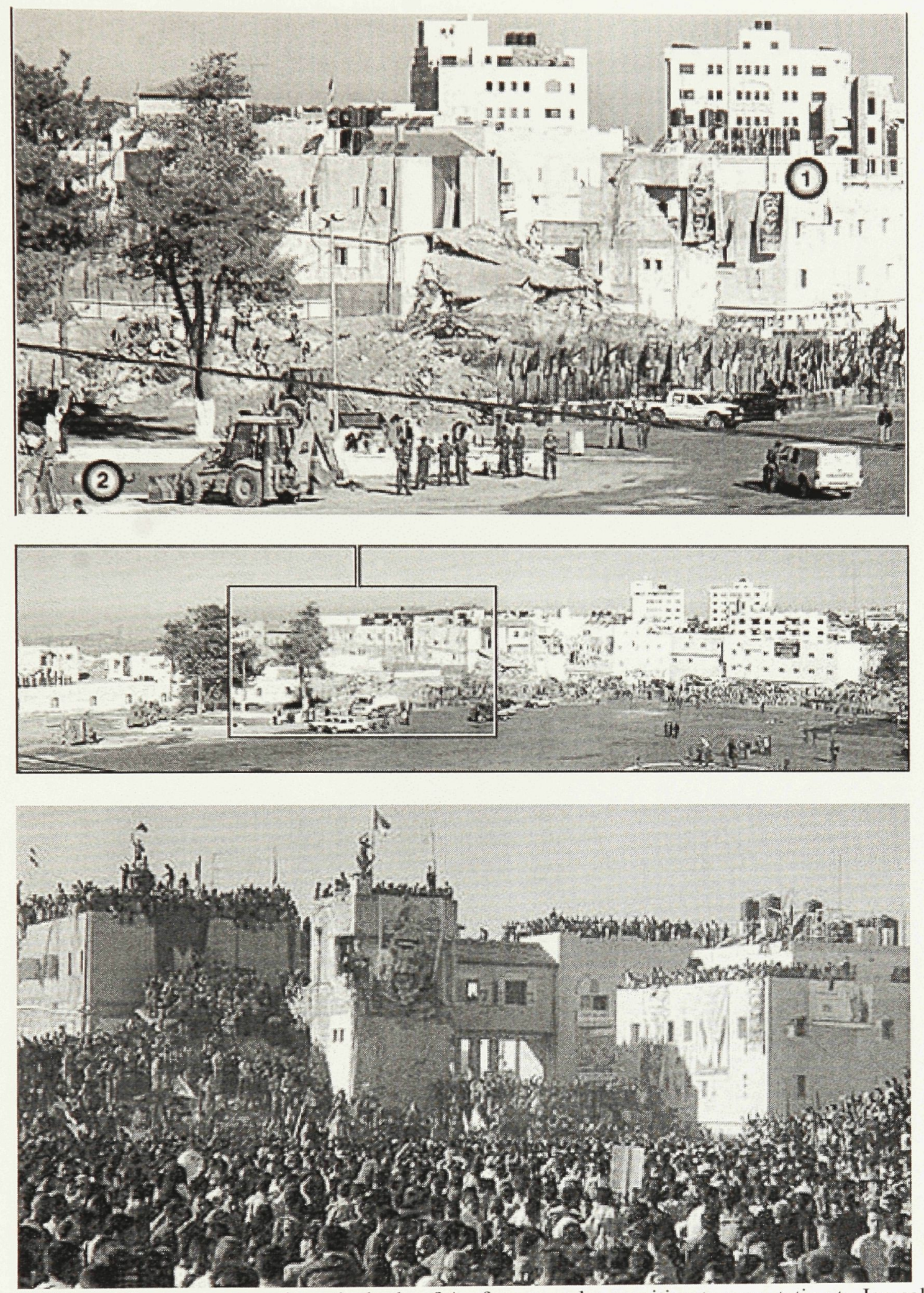

(above)1. The conference centre where the body of Arafat was to lay awaiting transportation to Jerusalem. 2. The burial site where Arafat has been buried after Israeli refusal to allow a burial site in Jerusalem. Arafat's body has been buried in a concrete coffin that could be moved to Jerusalem easily in the future. ${ }^{144}$ (below) Yasser Arafat's funeral at the Mukataa November $12^{\text {th }}$ and $13^{\text {th }} 2004 .{ }^{145}$

144 BBC NEWS. Arafat's Burial. Friday, 12 November, 2004. http://news.bbc.co.uk/2/hi/middle_east/4006437.stm 145 Fahmy, Maria. Two Days at the Muqata. November 12th \& 13th 2004. http://www.eappi.org 

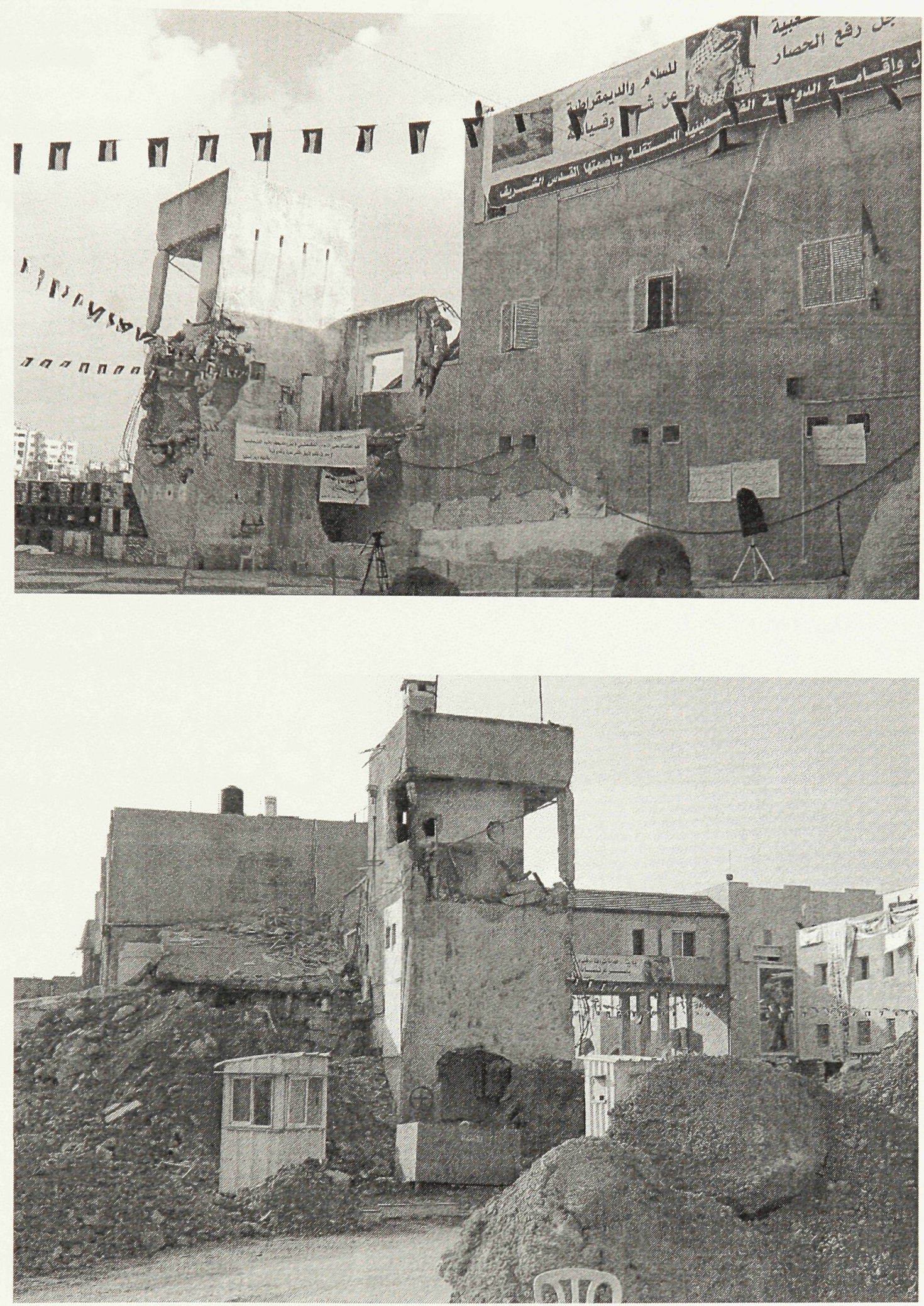

(above and below) Views showing the disrepair of the Mukataa in 2003. ${ }^{146}$

146 Guerrero, David. Midddle East Trip 2003. http://www.david-guerrero.com [Online March 26th 2005] 


\section{Conclusion}

Architecture is a series of forms, materials, and spaces representing a series of metaphoric intentions that form a narrative of place. The Palestinian National Library is a series of stories that expose some aspects of Palestinian cultural identity. This is accomplished through the relationship between the viewer, their perception and interpretation, and the architectural intentions explained through the conceptual embodiment of the project. The narrative can be seen by the way in which the building has been organized, through its spatial interconnections, forms, and rich material palette.

The library is symbolic in nature. It speaks of the destructive nature of civilization and the emergence of a Palestinian nation from the dark prisons of occupation. It shows the transformation of war materials into international institutions of knowledge. It represents the Palestinian struggle as a culturally based weapon. It reveals the temporal nature of identity. It accepts the way that prisons of occupation have evolved into national institutions of governance. It reveals a way to read Palestinian history and a way to read Palestinian architecture in light of that history.

The Palestinian National library projects, receives, and produces the national cultural image of Palestine. The Palestinian National Library bridges two existing buildings through its central courtyard: the Palestinian Parliament and the Palestinian Authority Headquarters. The Library acts as the international arm connecting the Palestinian Parliament and the Palestinian Authority Headquarters with the world. 
The program of the National Palestinian Library exemplifies the regional culture identified with the territory of a nation and a nation's interdependence internationally. The National Library is a cultural collection of the nation, representing that culture's identity internationally.

The collection rises from the dark beneath the earth, forming a wall of knowledge that cuts through the landscape. An opaque wall of services flanks the porous wall of books. The central courtyard that bridges the existing buildings divides the wall of services such as kitchens, washrooms, elevators, stairwells, storage rooms, maintenance rooms, and theatrical lighting access bays, into two parts.

The books are organized chronologically. One enters the wall within the period of time you occupy, therefore experiencing a physical distance between one's own time and the past within the narrative of the wall. This physical space expresses the distance in time between when the collection was created and its present interpretation. The narrative of time found in the chronology of the wall distances the present from the past. This distance in physical space exposes the chronological nature of the narrative and forces the acknowledgement of time and distance in relation to interpretation.

The books, a catalogue that, together, form a portrait of Palestine, must be indexed by the National Bibliographical Agency. The National Bibliographical Agency forms the bulk of the staff. "The national bibliographical agency should have as its first priority 
the compilation and publication of the current national bibliography." 147 This national bibliography empowers the image of the nation on an international scale. The threestorey space provided for the National Bibliographical Agency has the capacity to be subdivided, as greater office space is needed in the future.

The National Bibliographical Agency is also responsible for the collection of foreign literature pertaining to Palestine. The foreign literature integrates the world's perception of Palestine with its own. As all national libraries must integrate the work of foreign nations, a large part of a national library's international responsibility is the publication and duplication of its collection. This, in a way, forms the mechanical underbelly of national libraries.

In the Palestinian National Library, these functions, housed in the publication and duplication lab, are found deep within the excavated earth, symbolizing the archaeological digs that helped form our scientific and historical understanding of the territory. One can peer down within the earth from various vantage points and witness the production of Palestinian international identity.

The reading room itself is excavated from the earth. It overlooks the reproduction of the studied works, appearing like artefacts within an archaeological dig. The collection is accessed from the reading room below the surface of the earth. The ascent from below the surface up into the light dramatically reveals the collection against the regional 
reality. The collection that is the international collective identity becomes a costume through which we view the regional landscape.

"National libraries should organize permanent and special exhibitions to illustrate the cultural and scientific achievements of the country and of the world." 148 The exhibition space placed on the ground floor to facilitate easily rotating exhibitions maintains a transparent relationship with the surrounding landscape. The Palestinian National Library is also equipped with a media room opening onto the adjacent olive orchard. The olive orchard provides a cultural backdrop for events such as news releases and parliamentary announcements. An auditorium directly above the media room can be used for such events as book inaugurations speeches and cultural lectures.

As the production of a national library's collection grows exponentially, the project is conceived as the first phase of the building, symbolizing the commencement of the Palestinian nation. The wall will continue to expand across the landscape, a physical manifestation of the territorial boundaries associated with nationhood. With each generation, a subsequent phase in the wall's development will have a new entrance into the narrative of time in accordance with the chronology of the wall.

The planning and development room floats above the library housed within a symbolic telescope looking out on the future. Within the telescope, planning and development officers prepare for the future growth of the library. 
Site Maps 


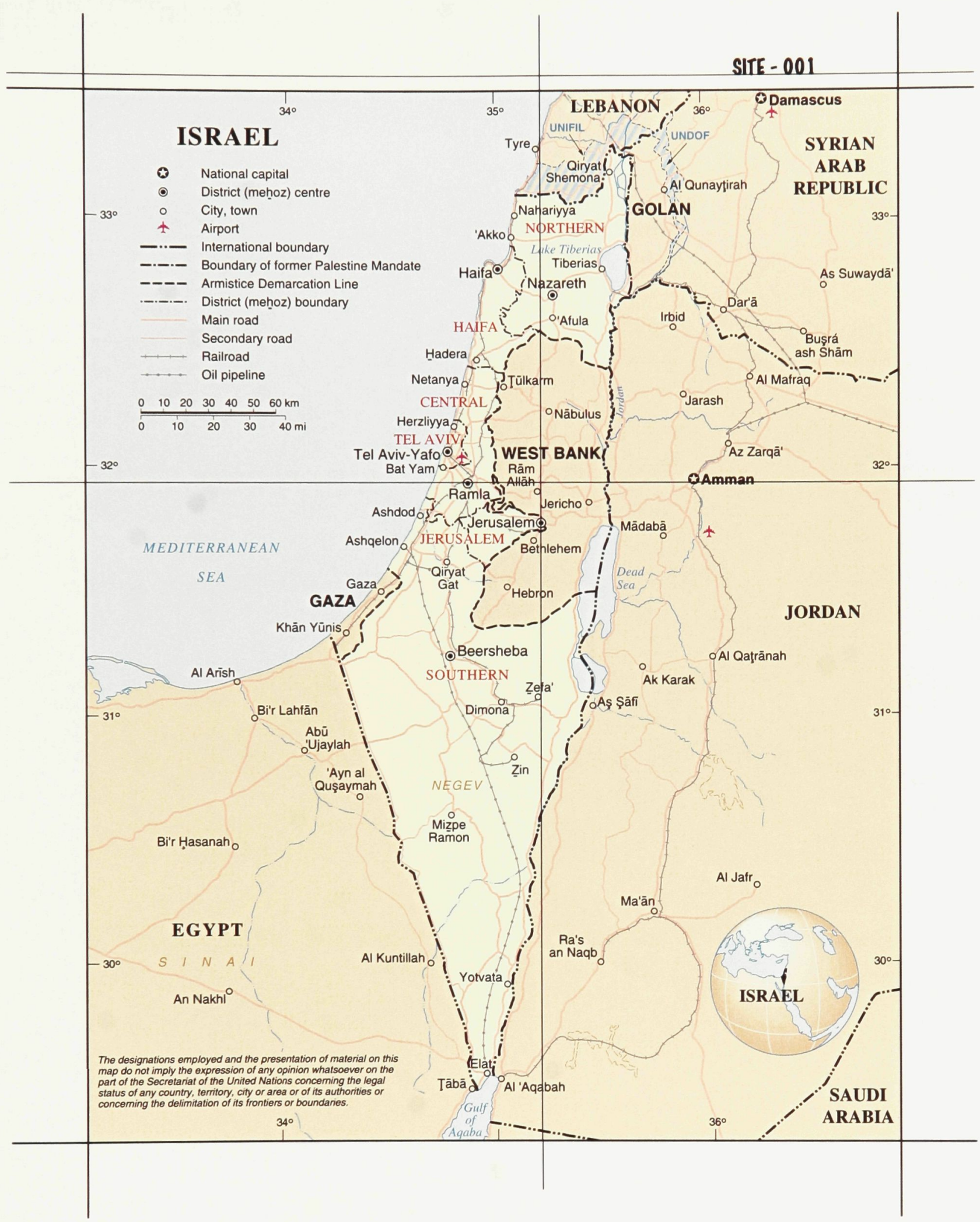




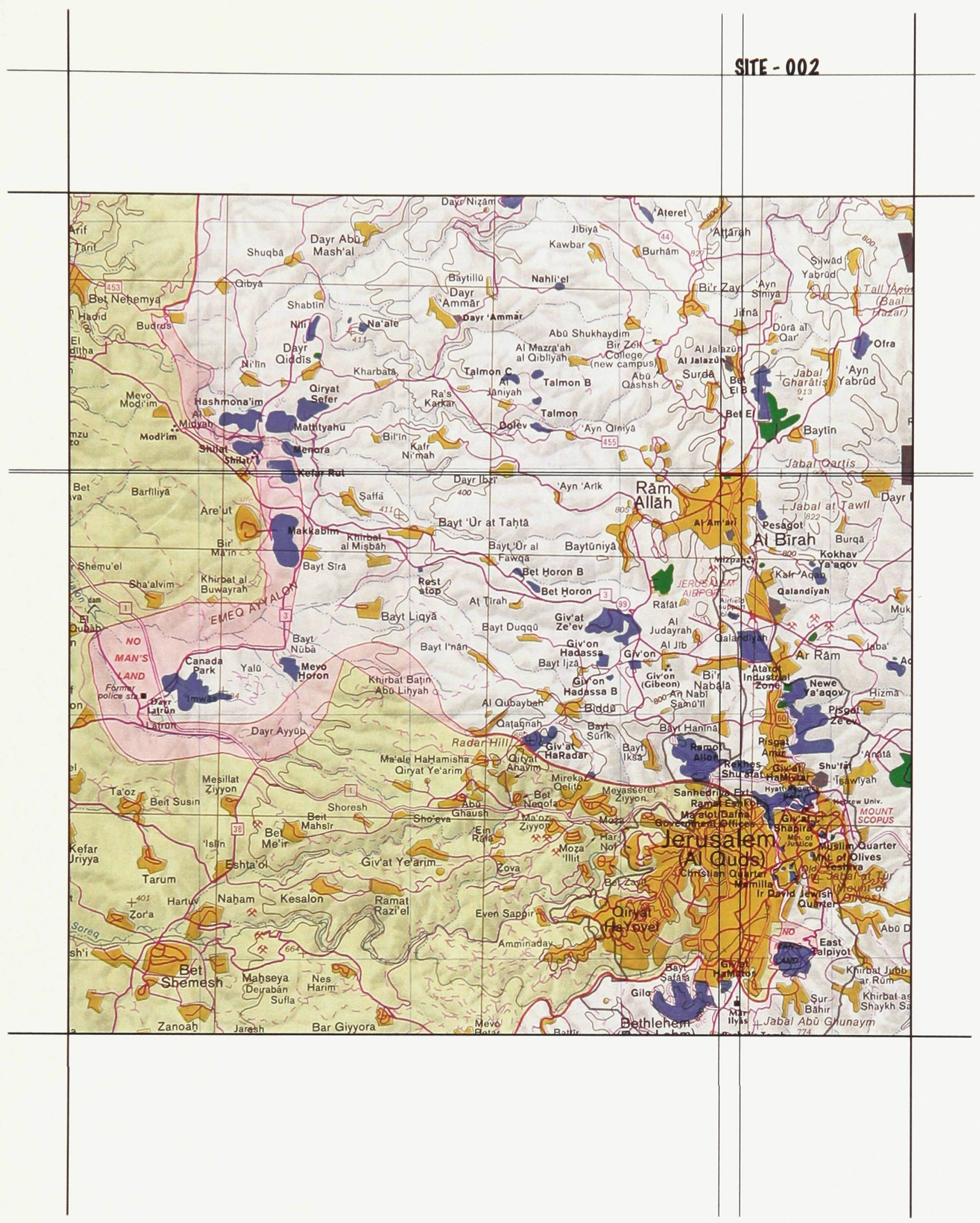




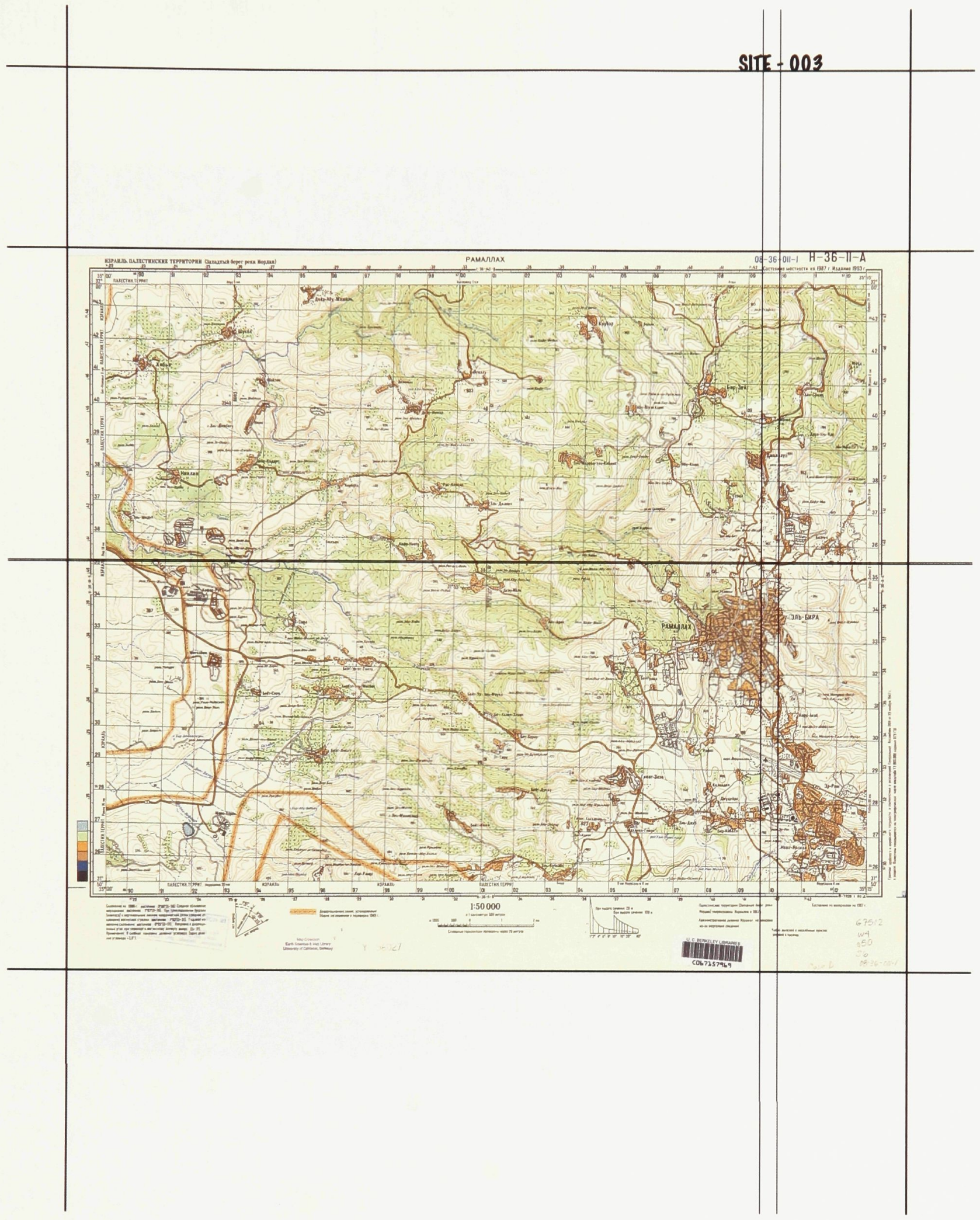




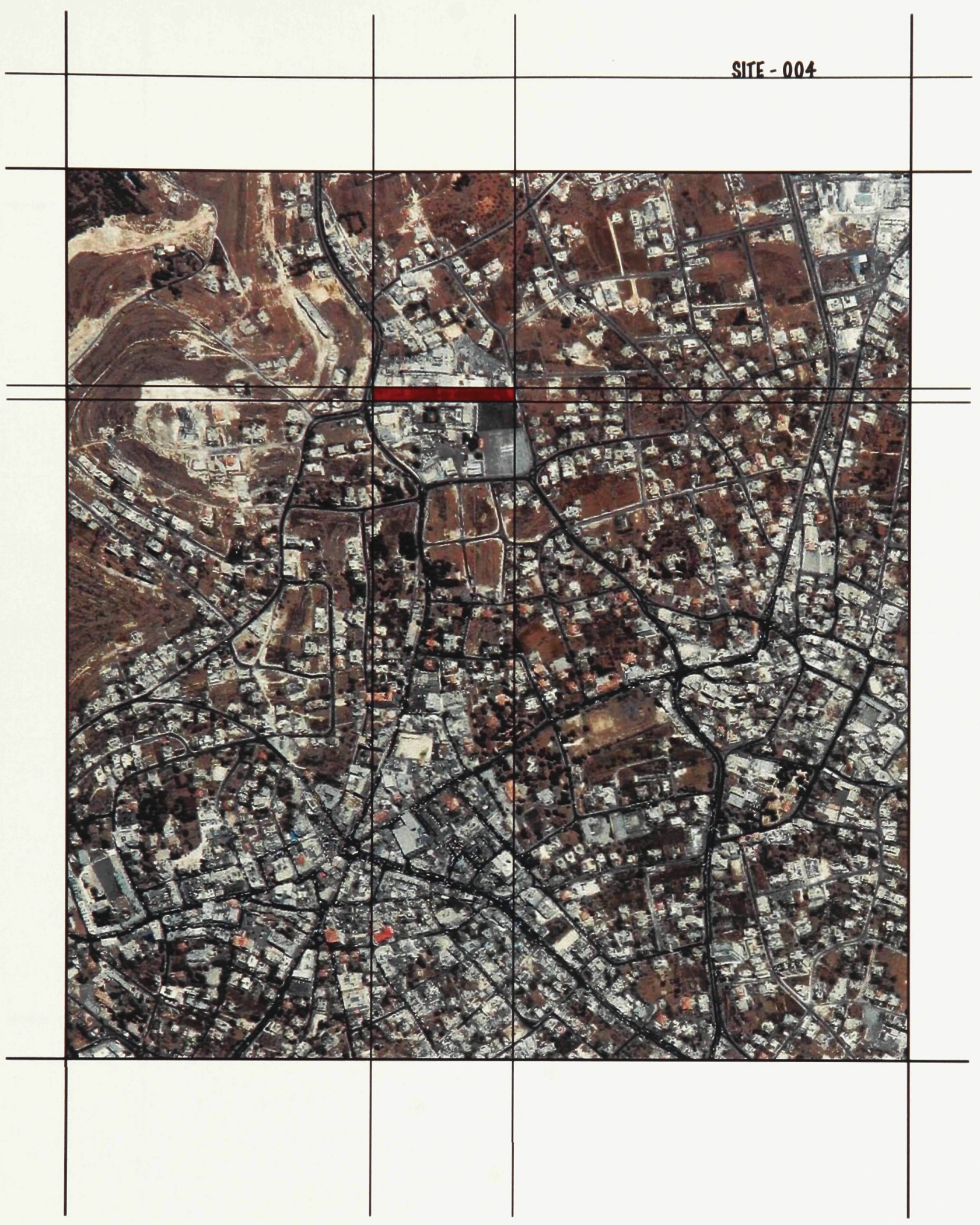




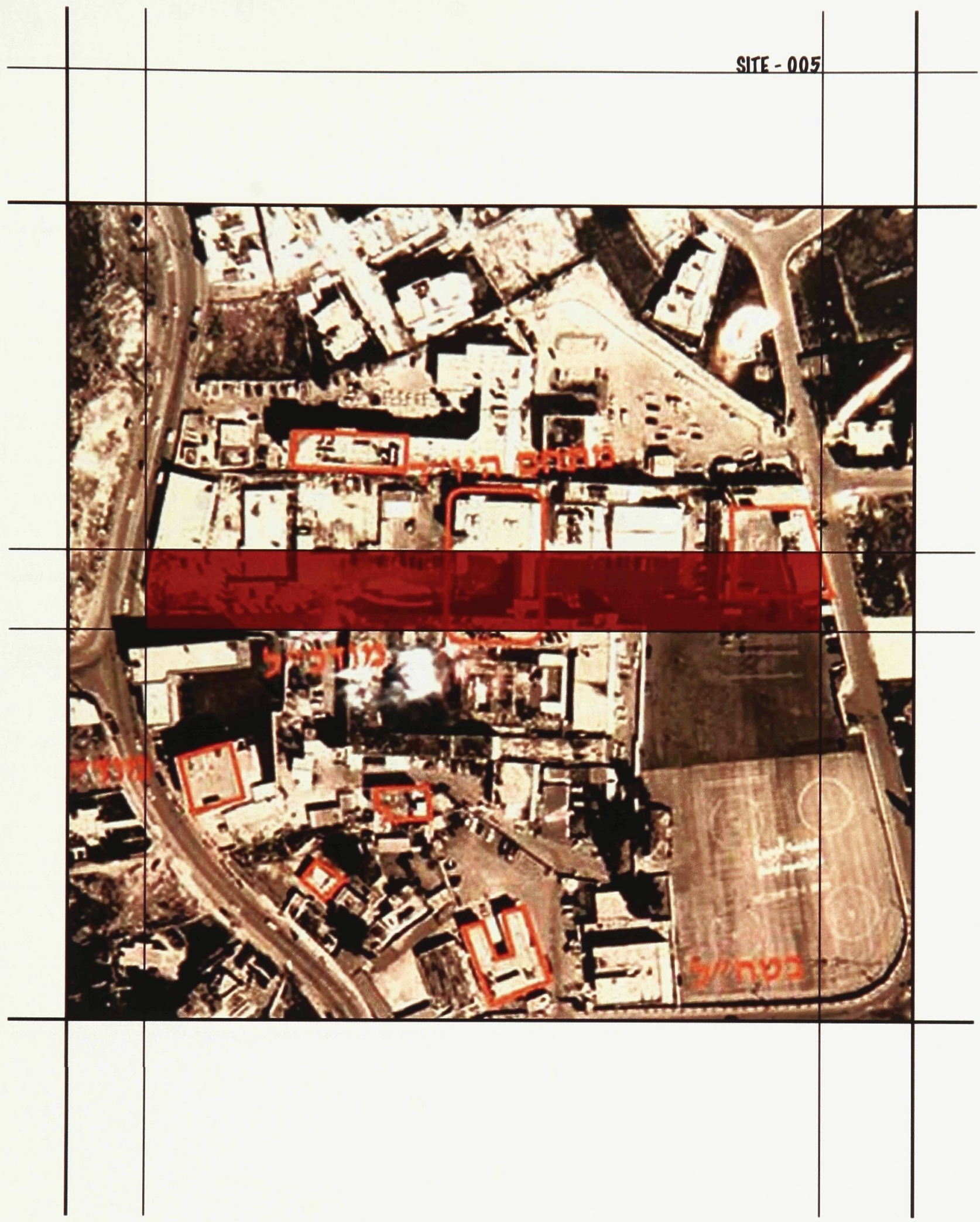




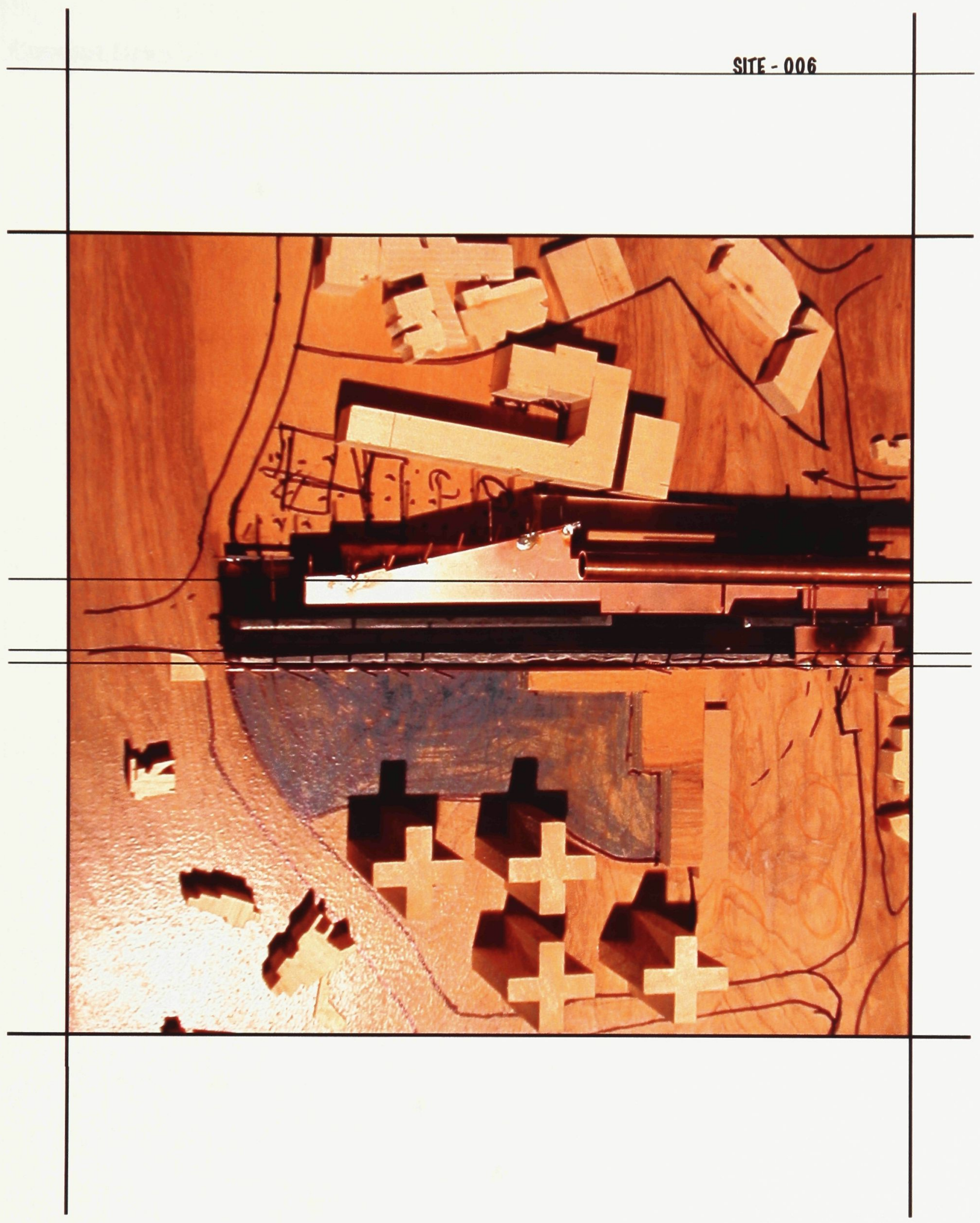


Concept Drawings 


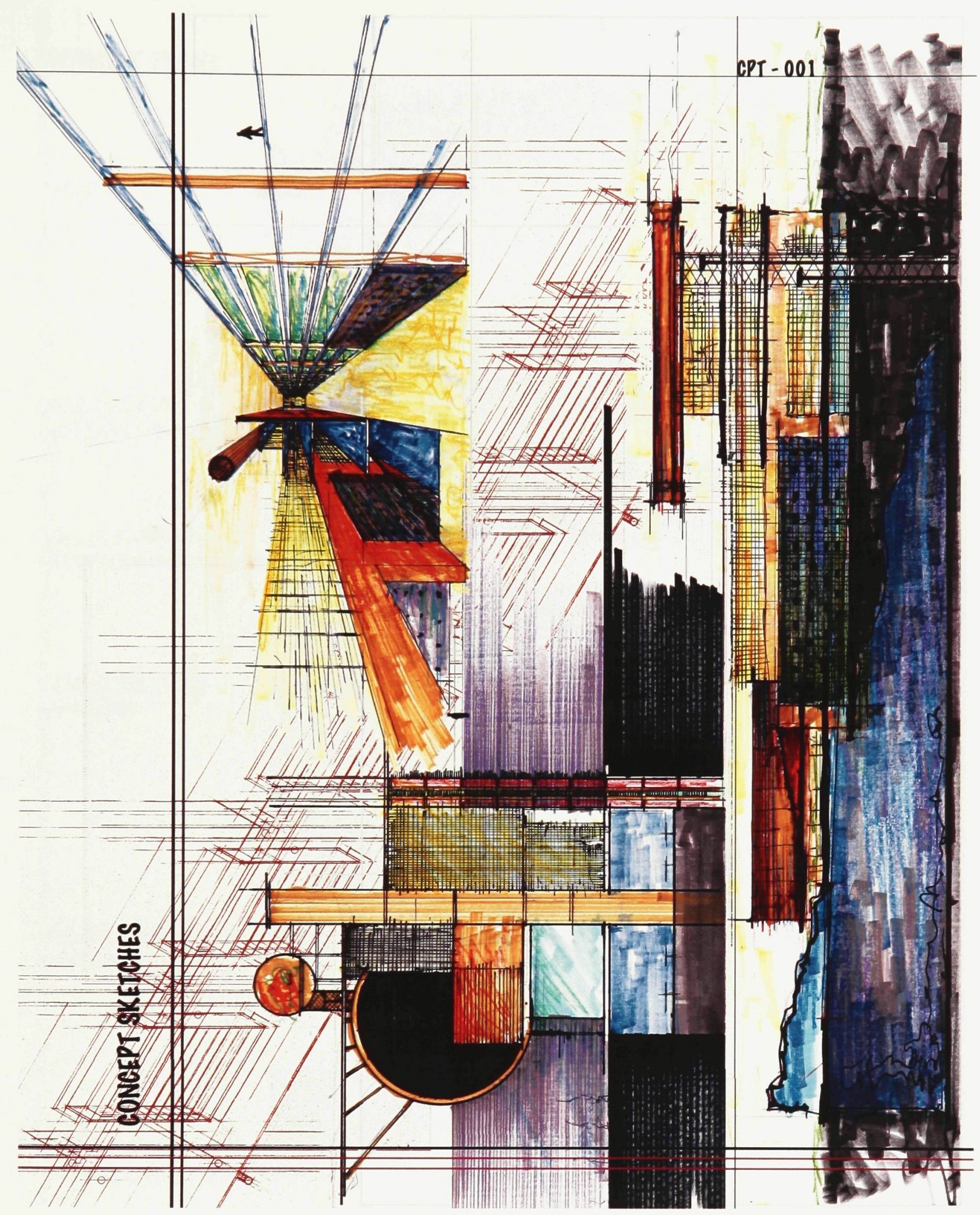




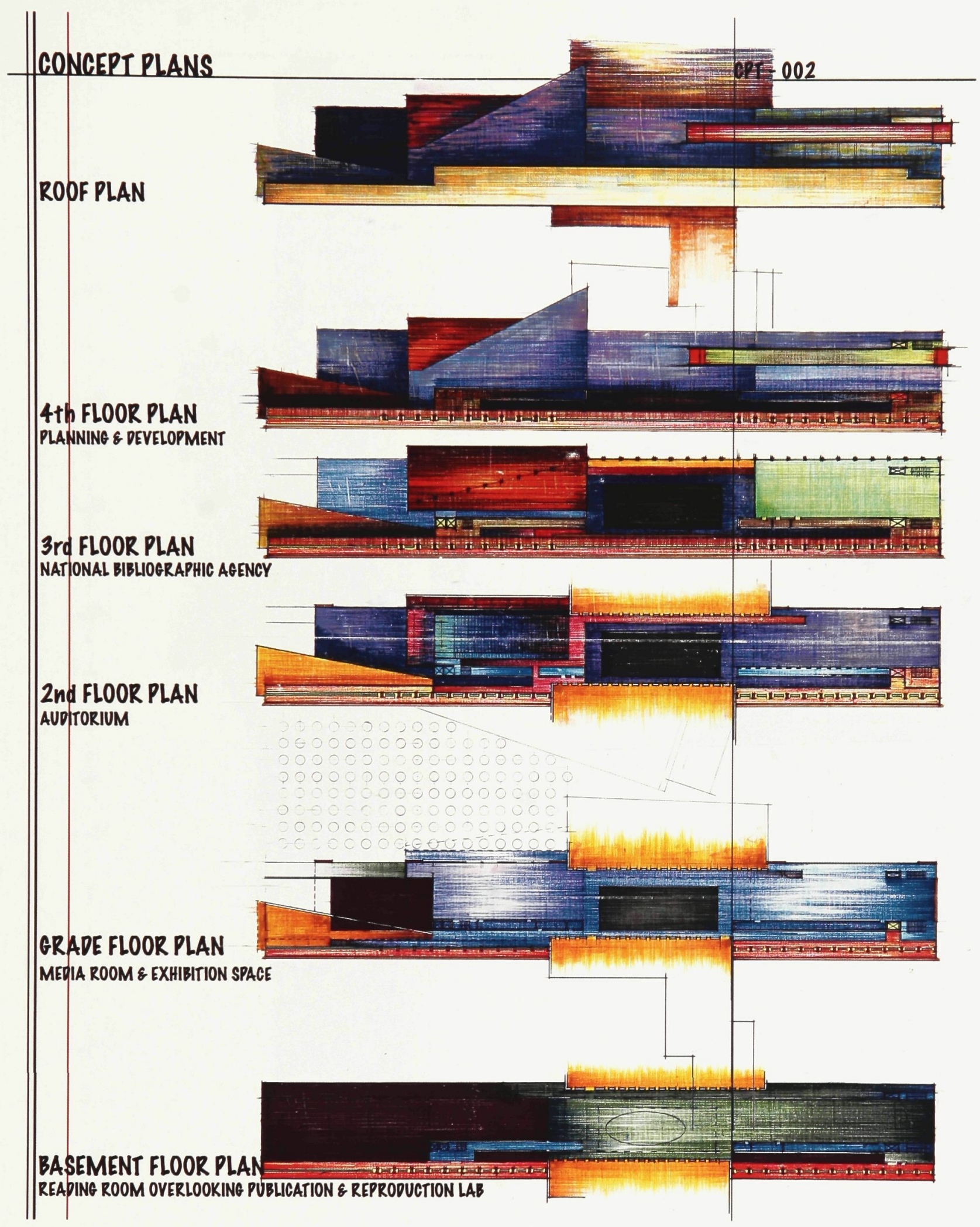




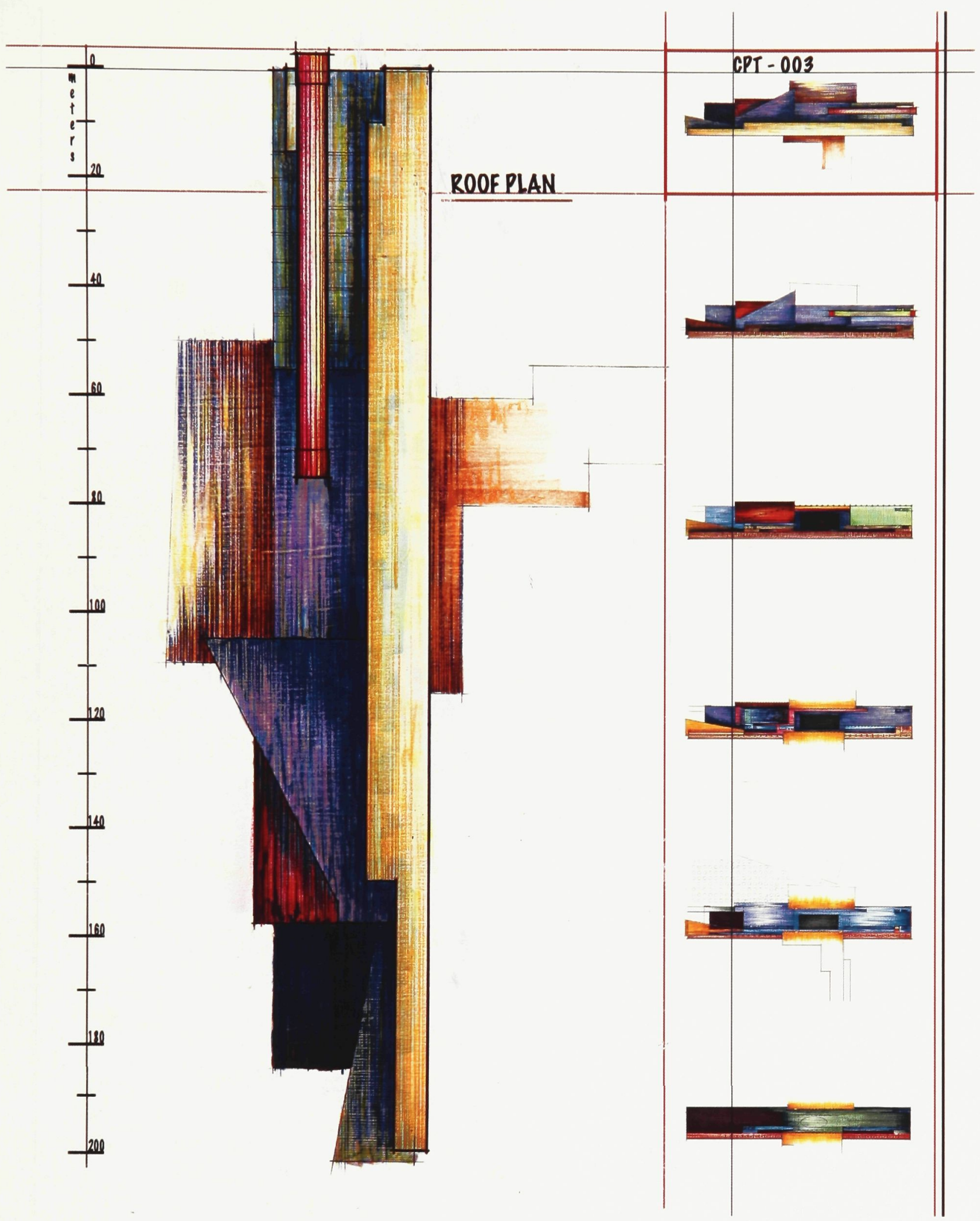




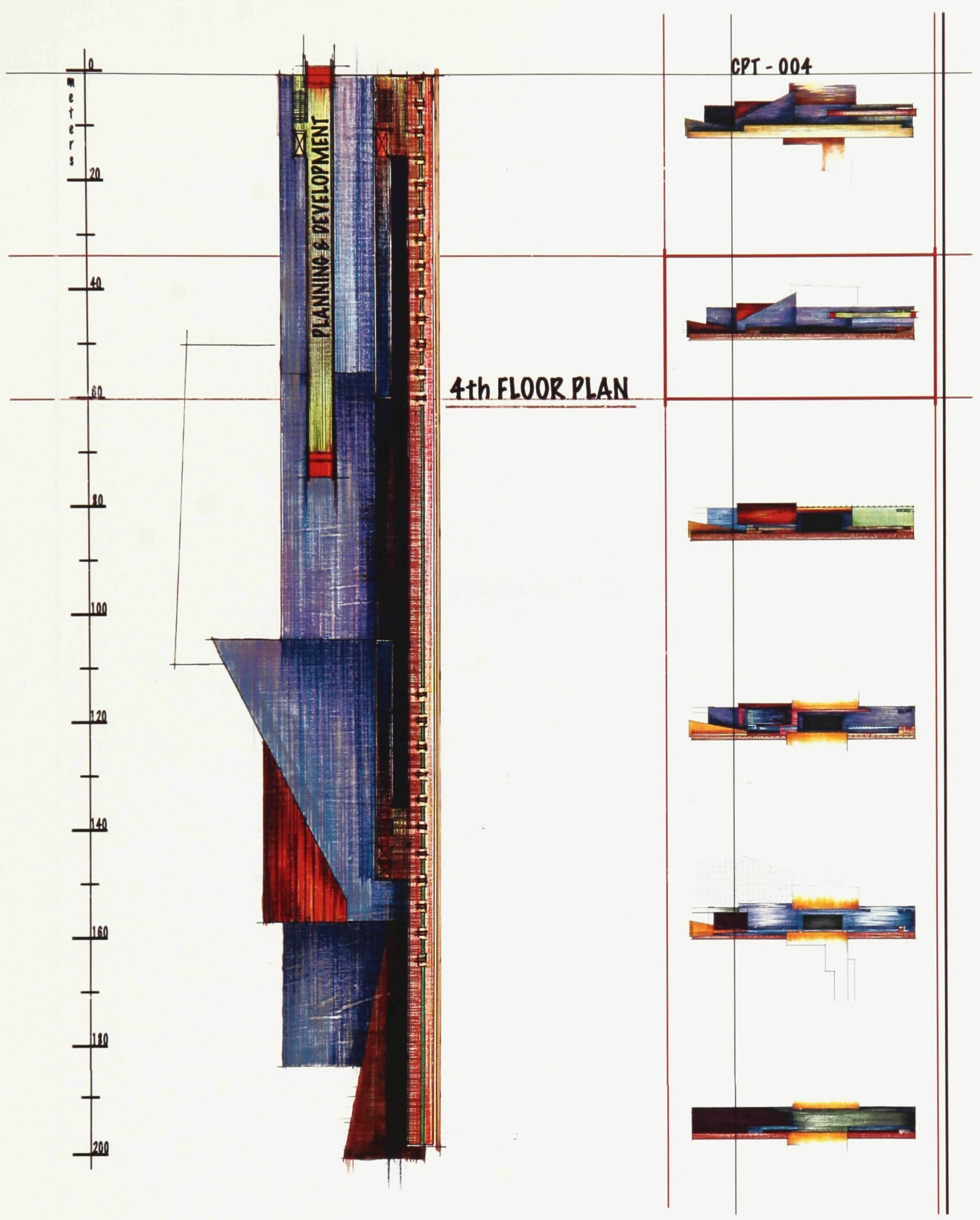




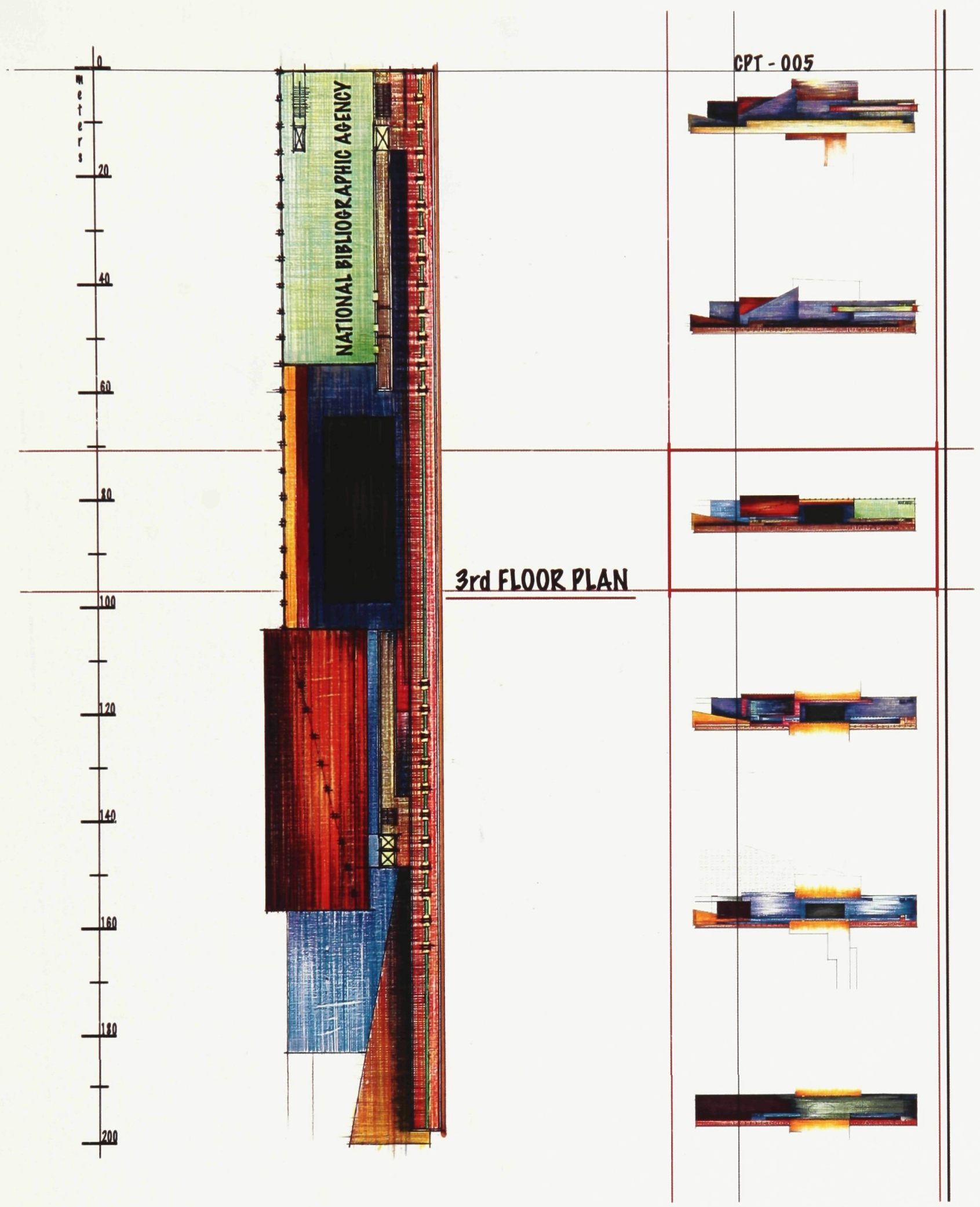




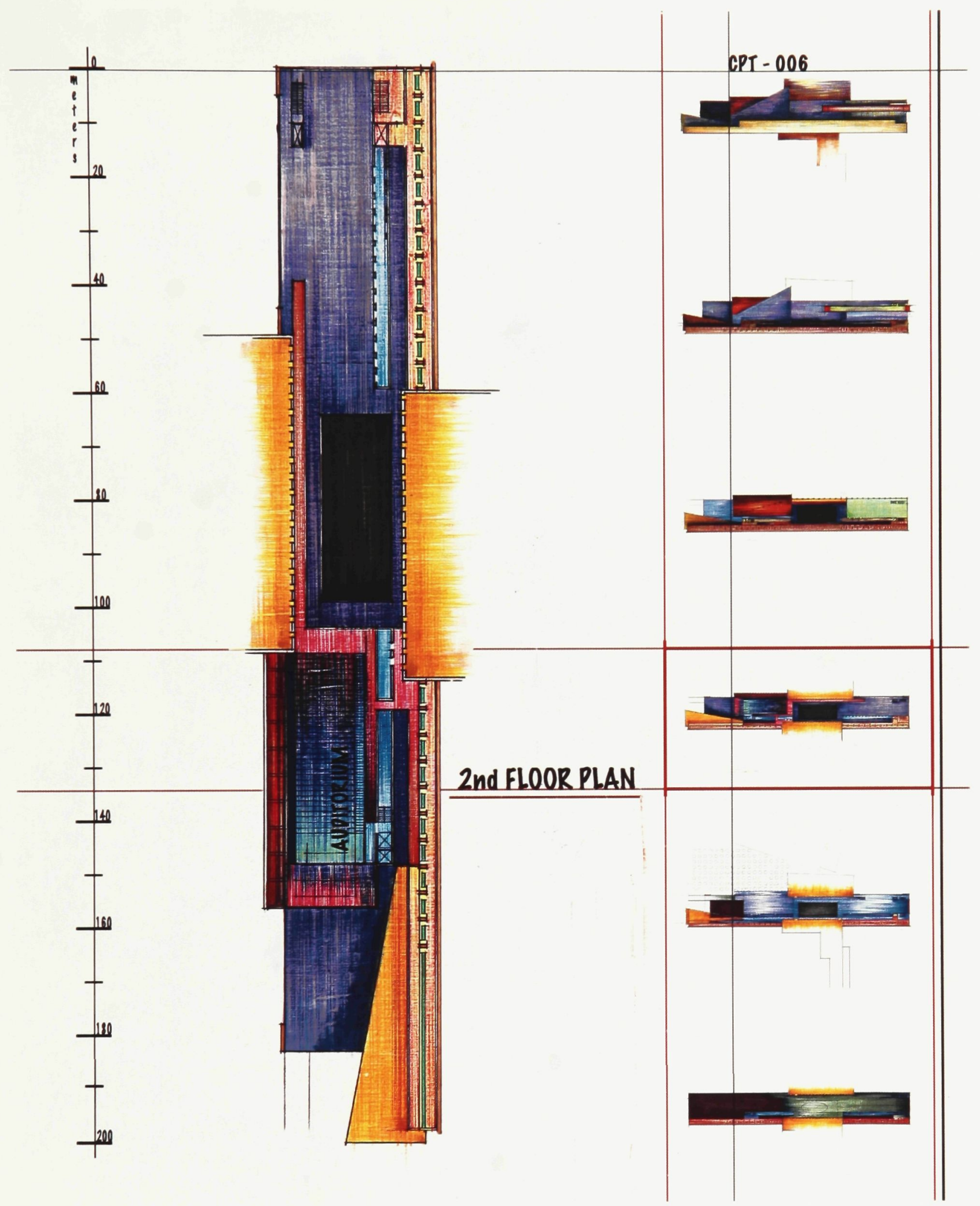




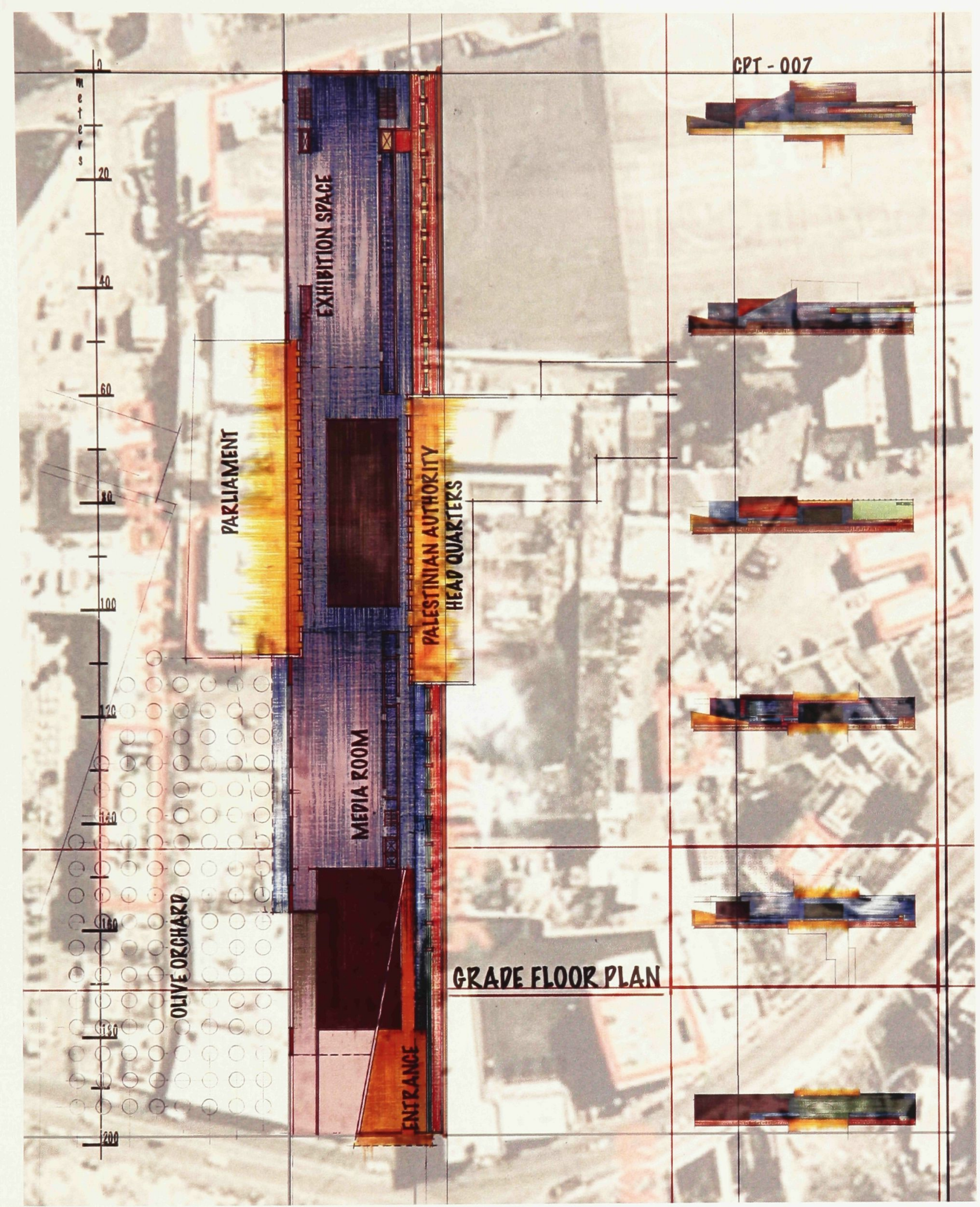




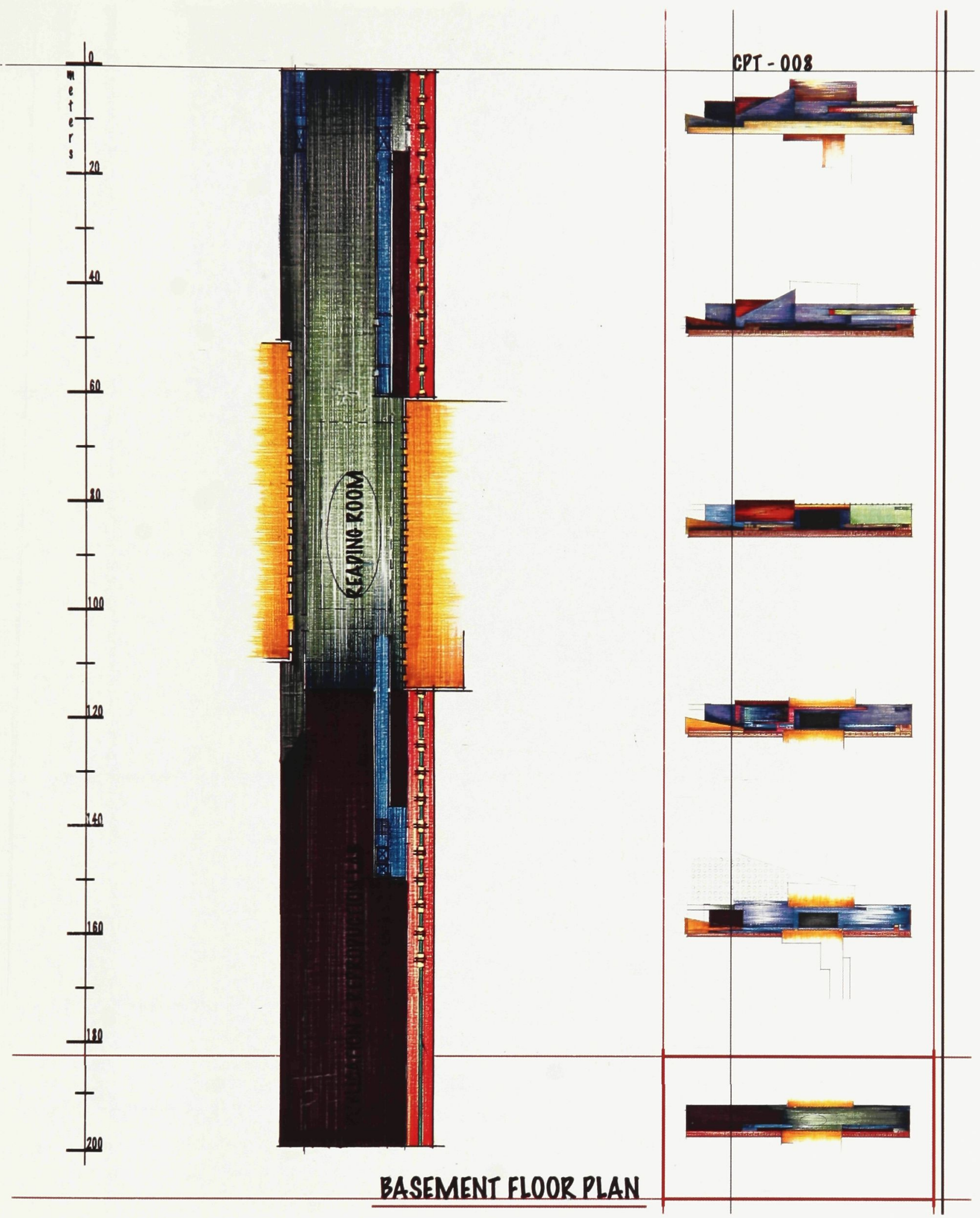




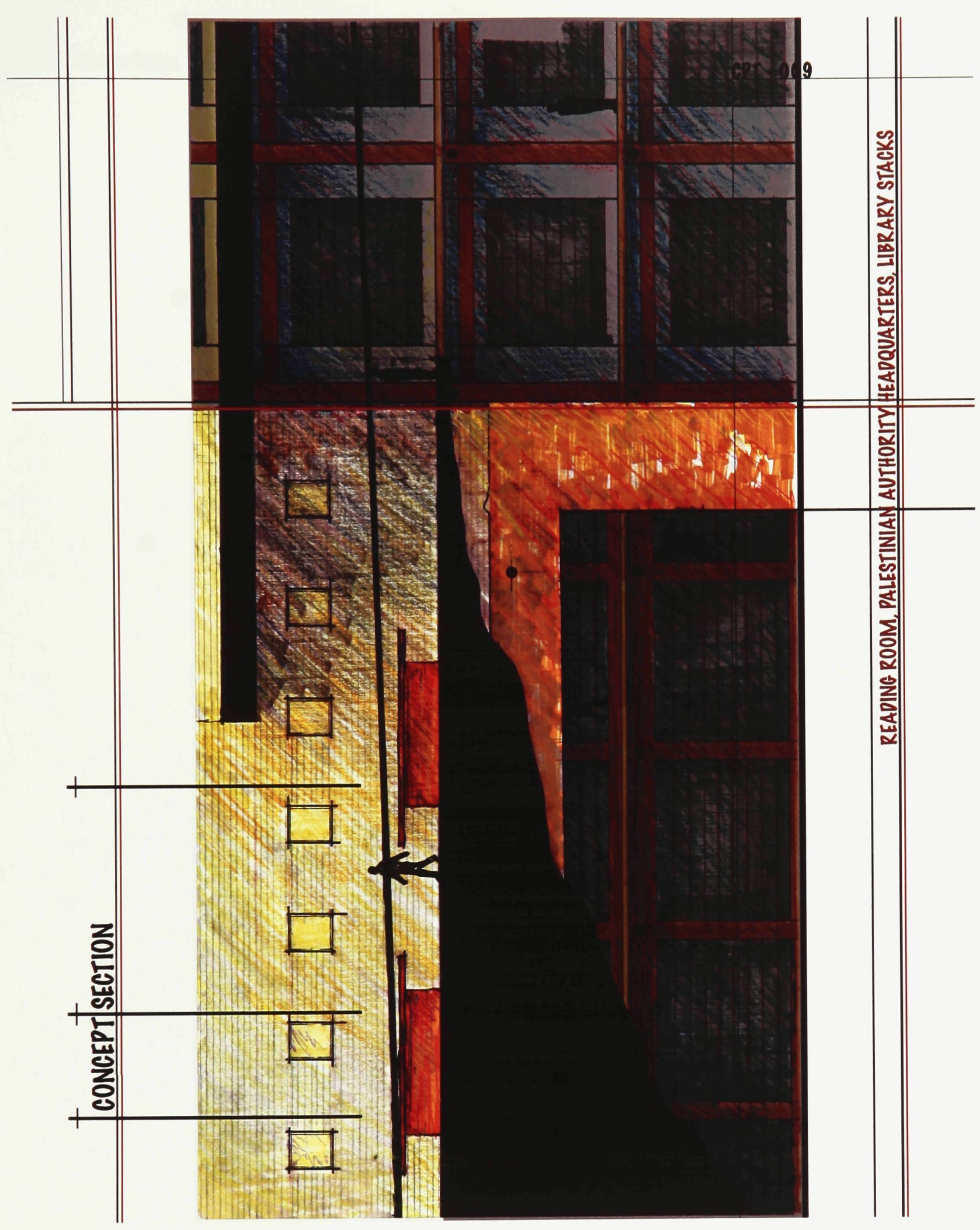


Line Drawings 


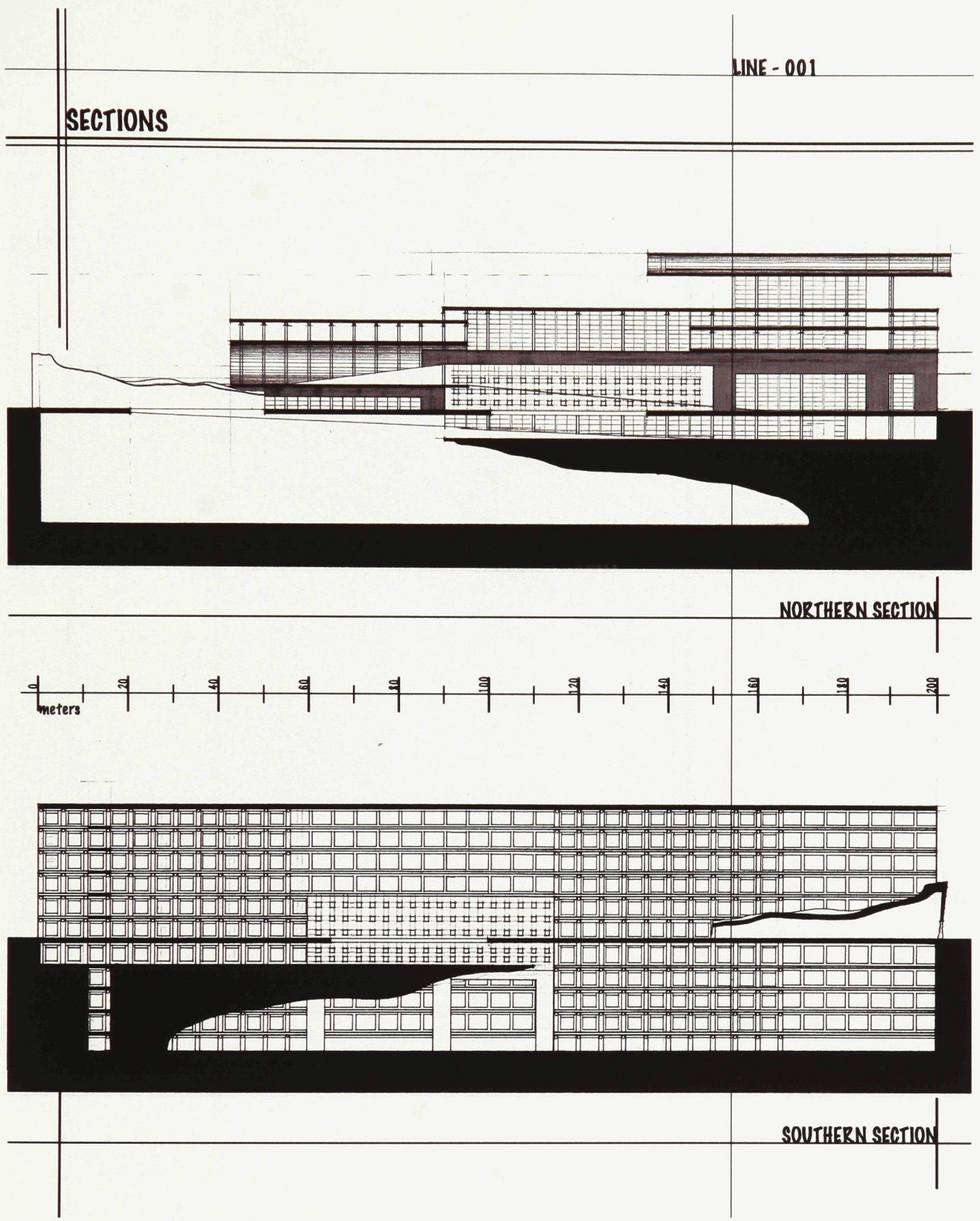




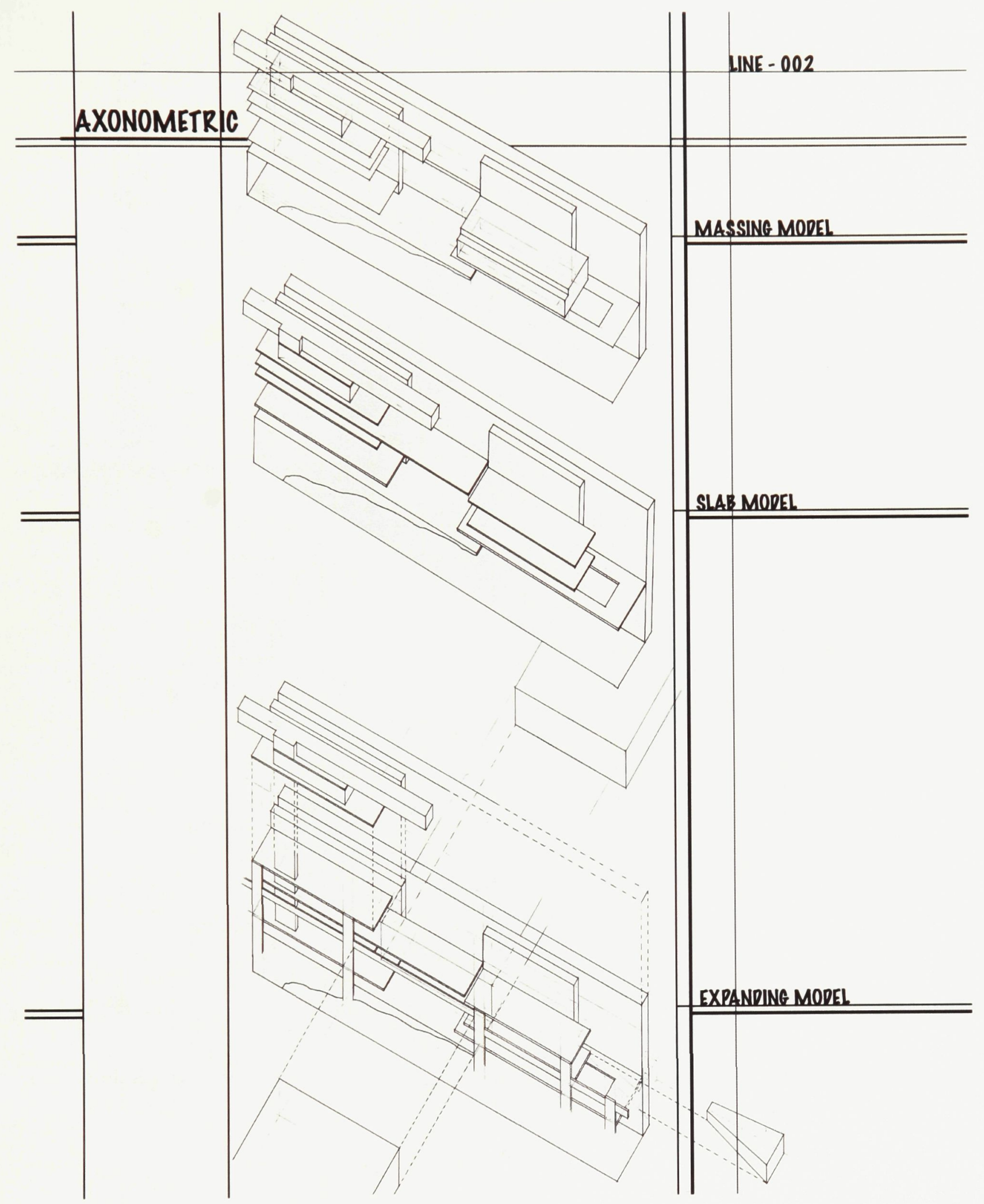




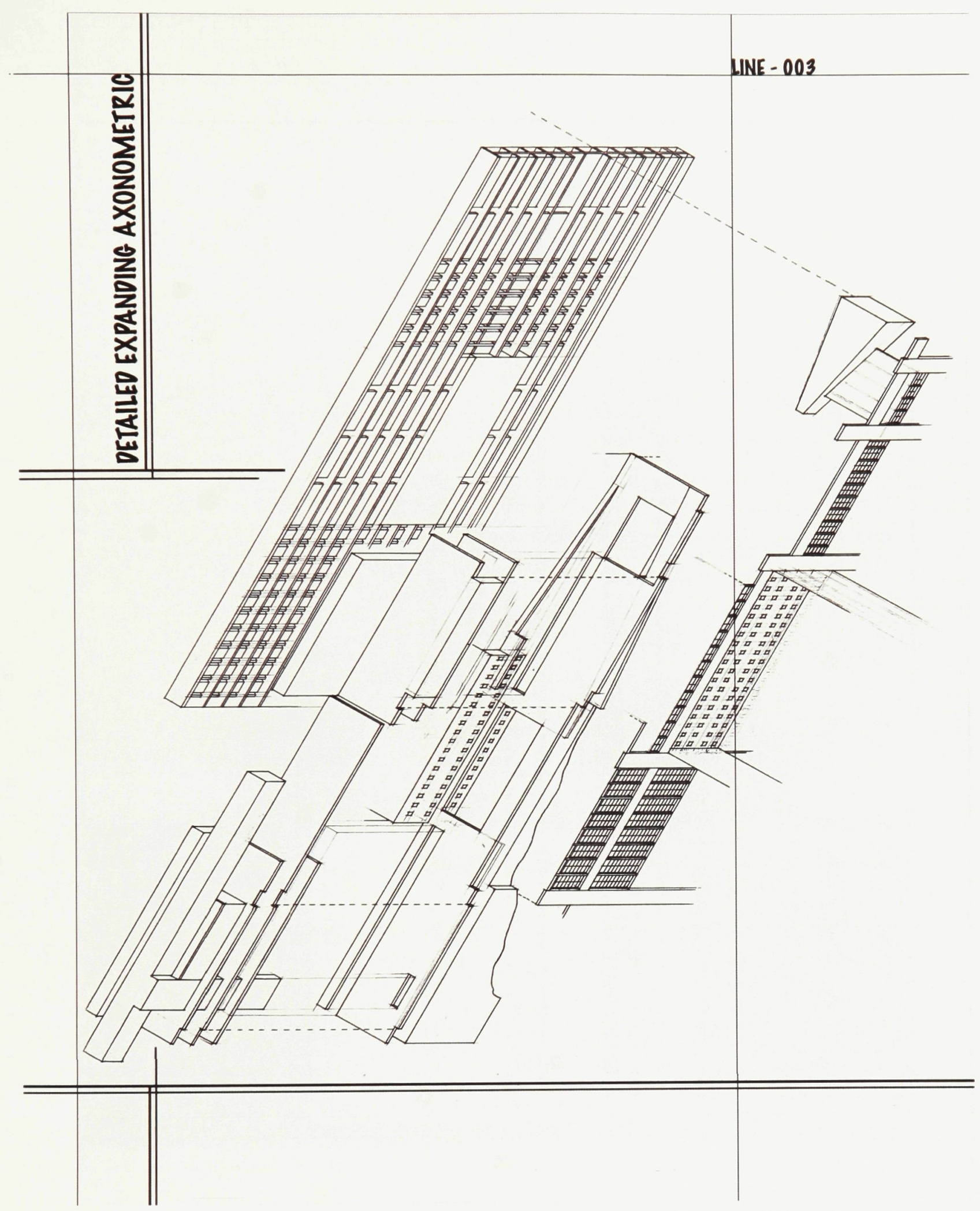




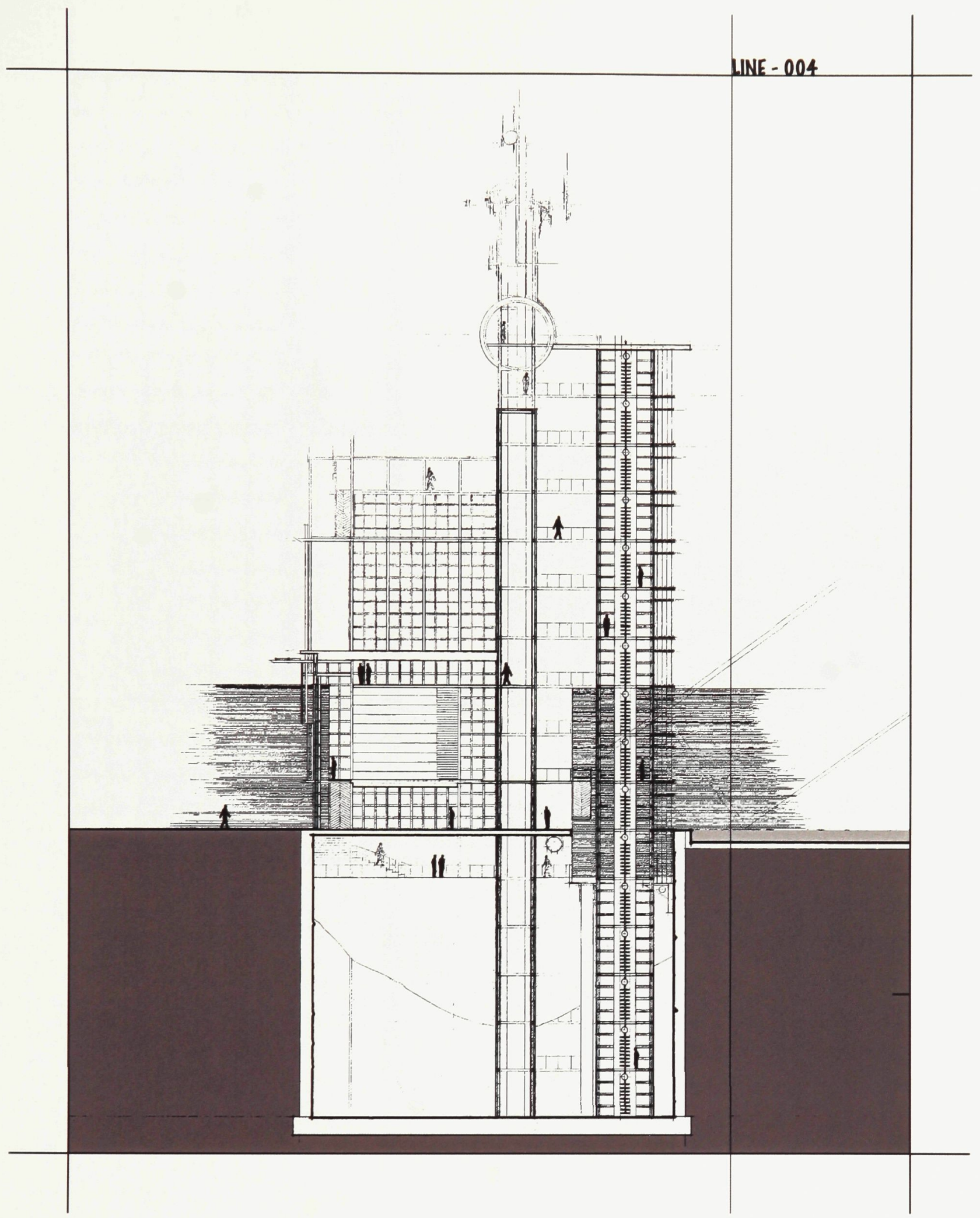




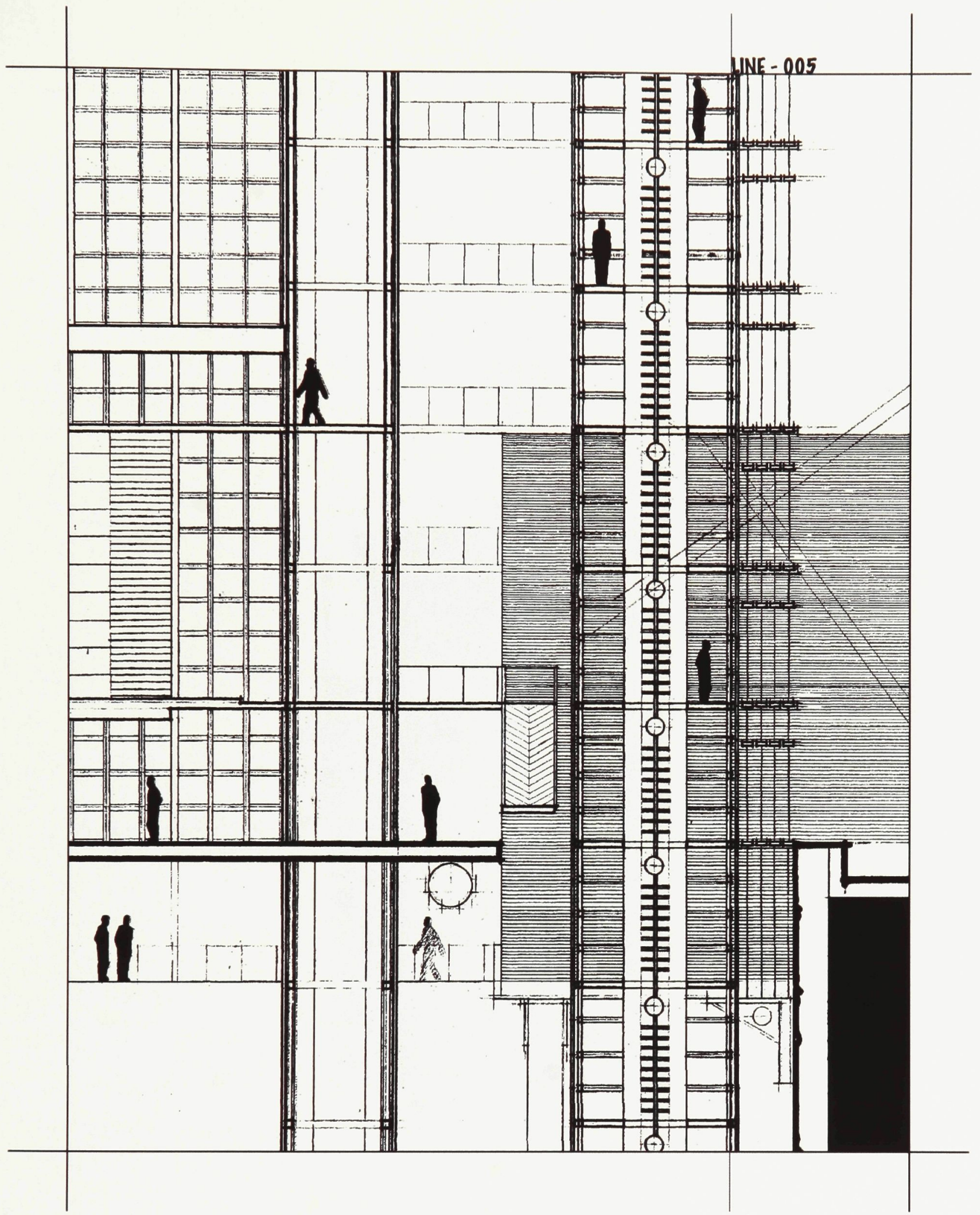




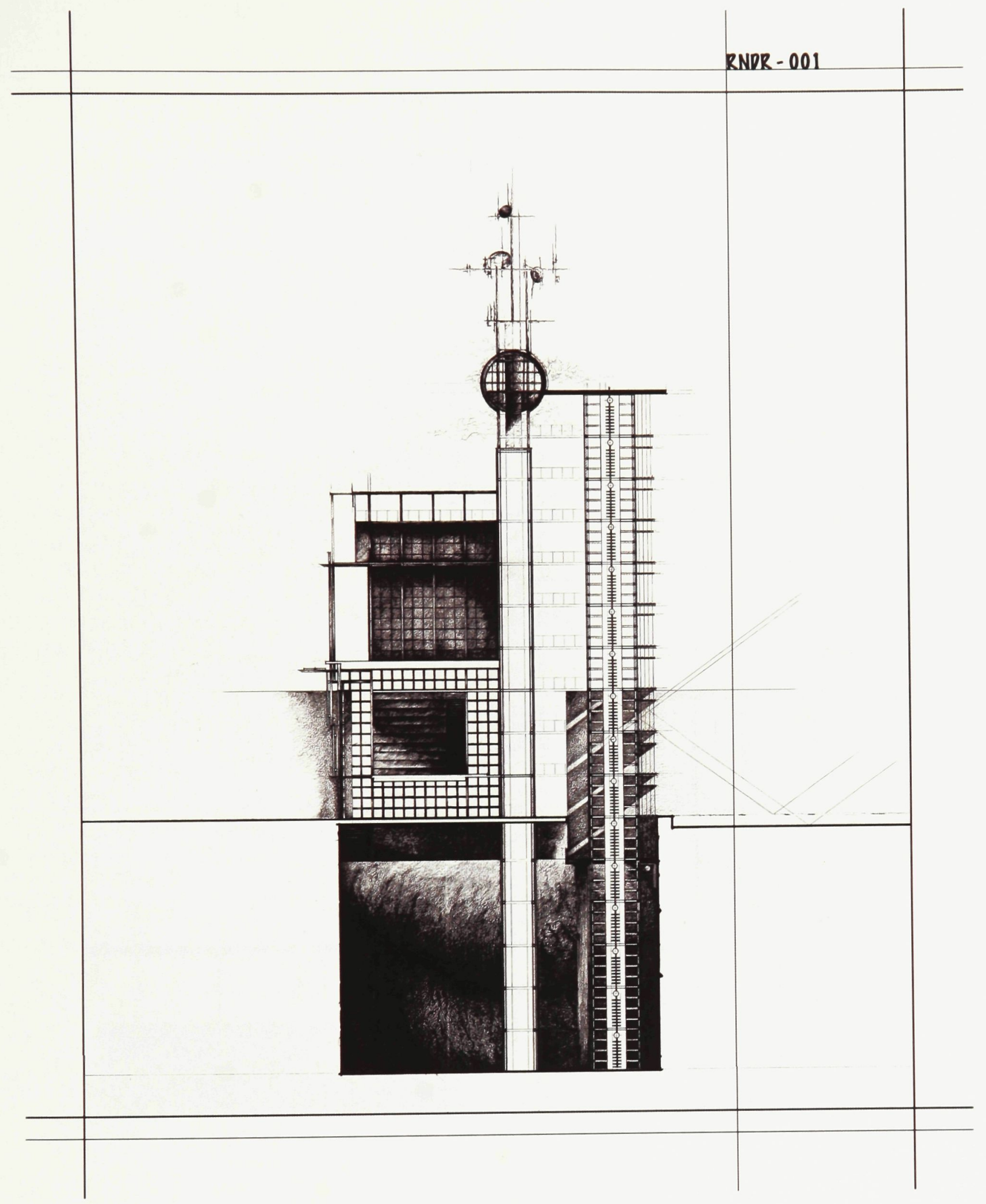




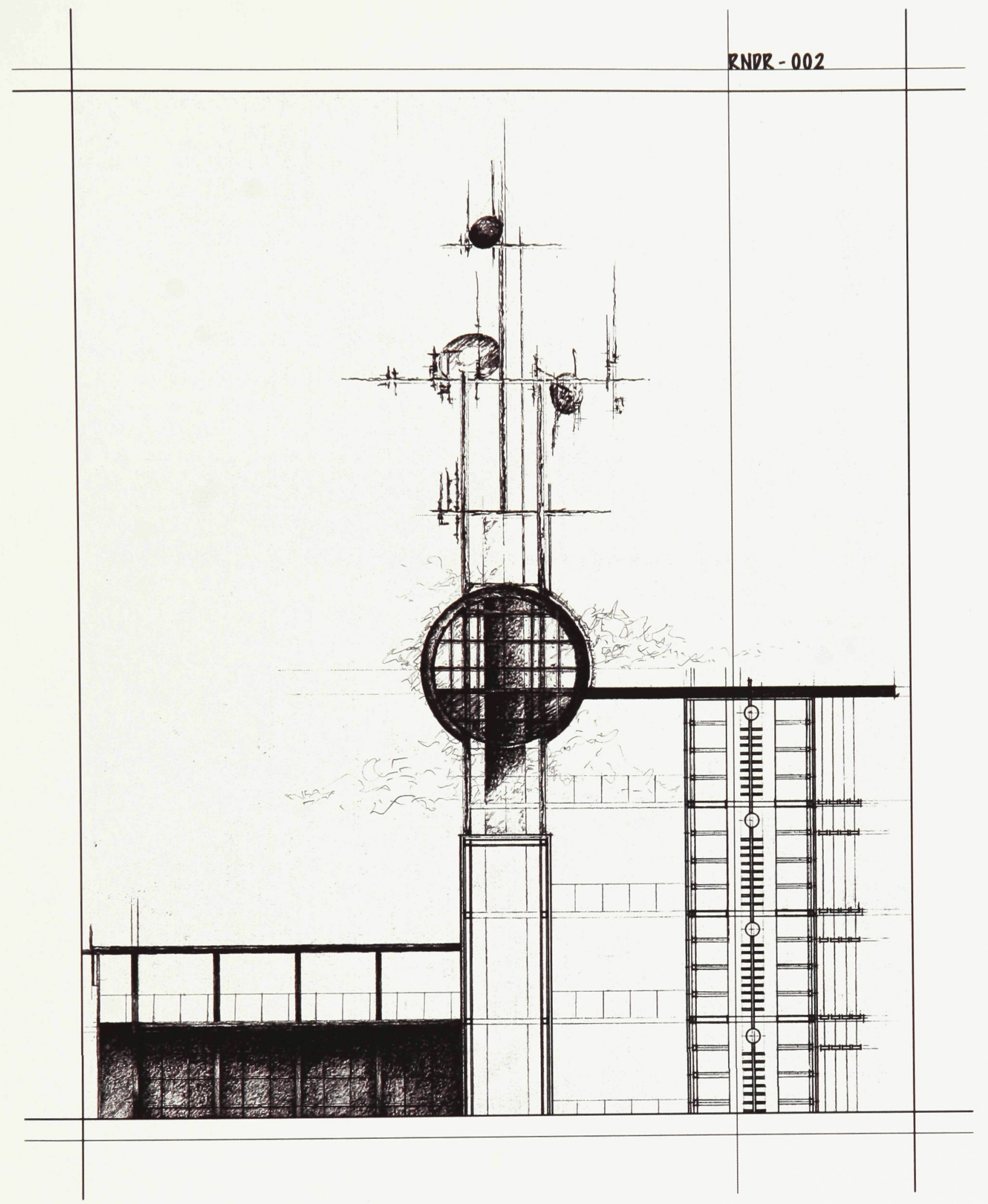




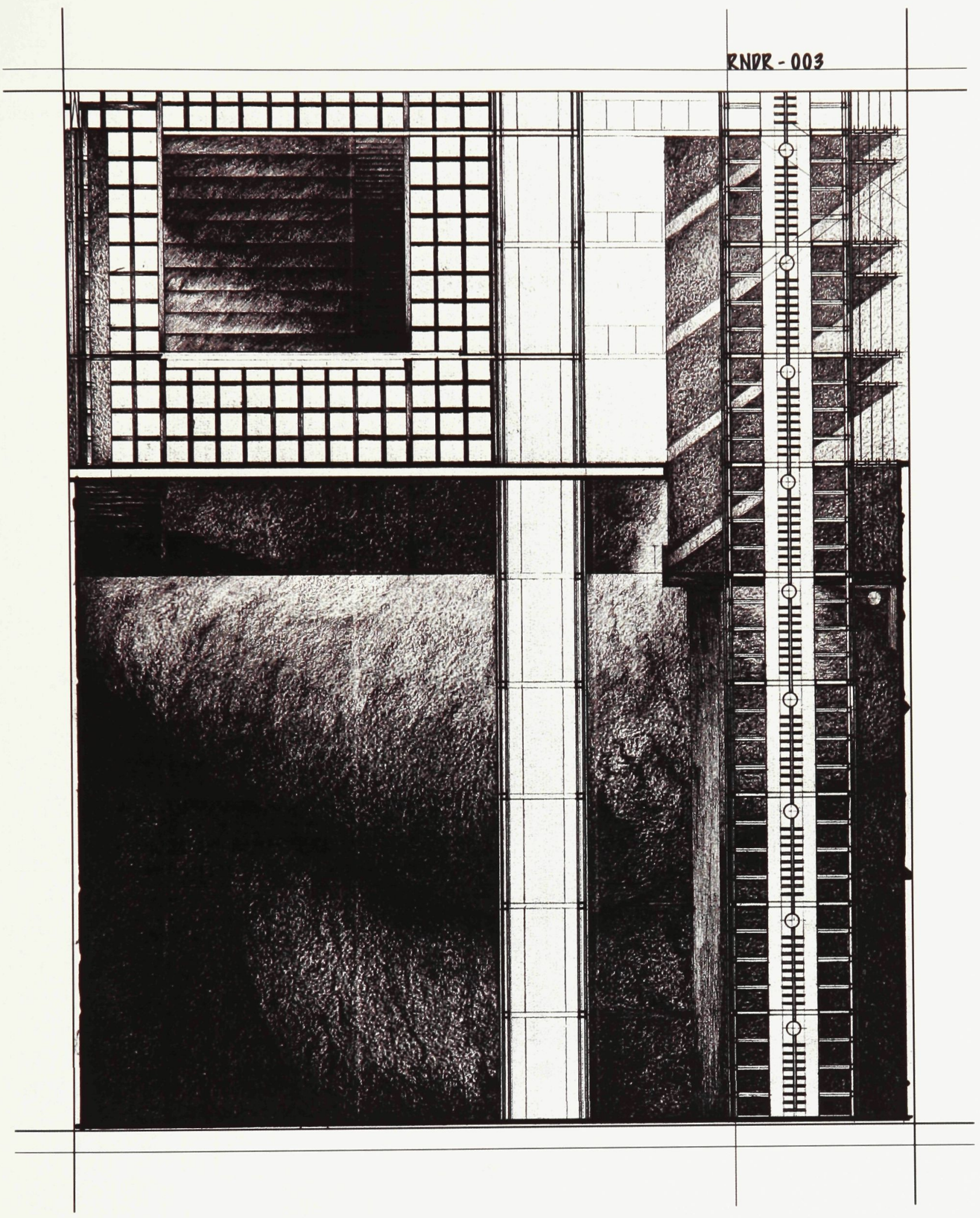




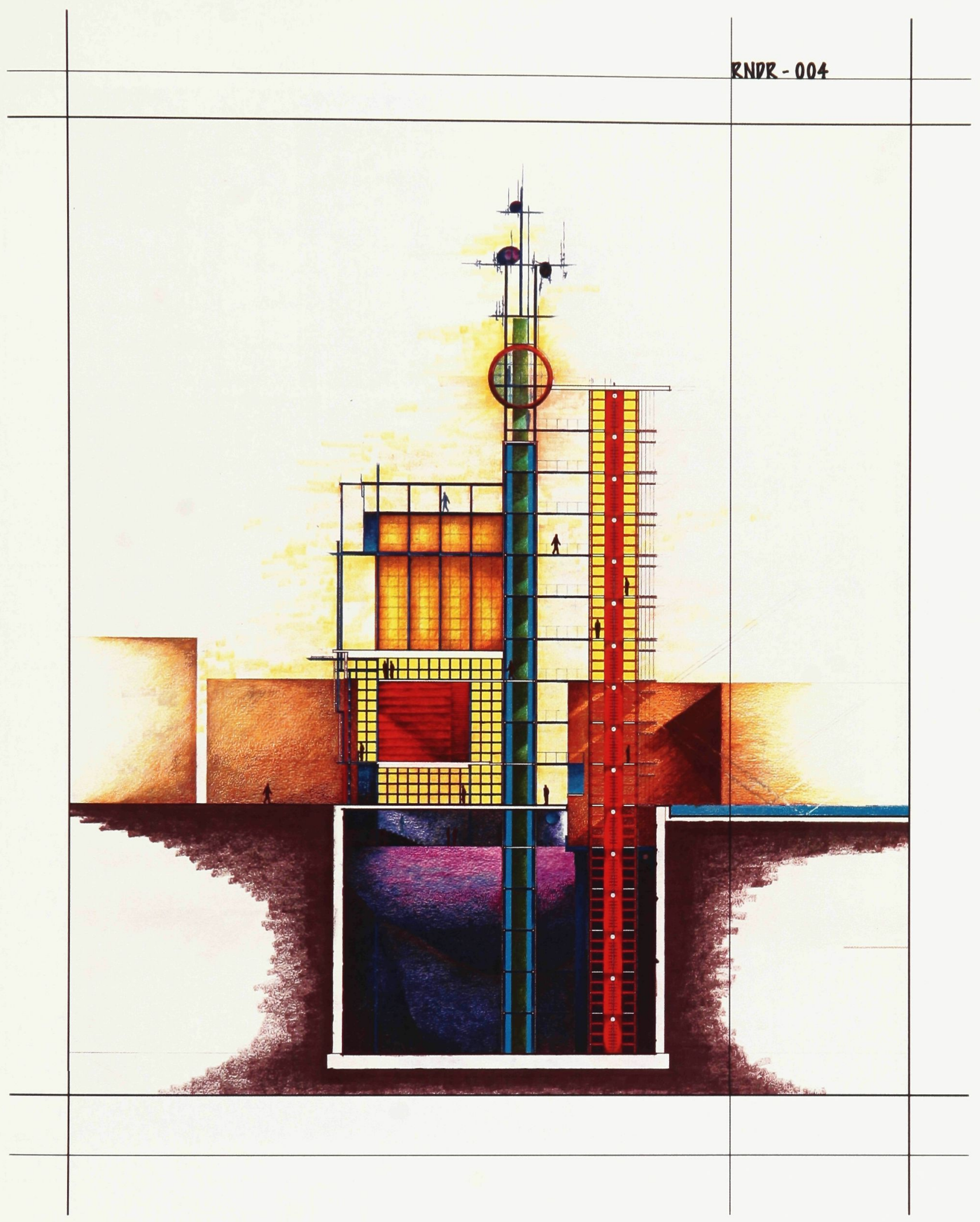




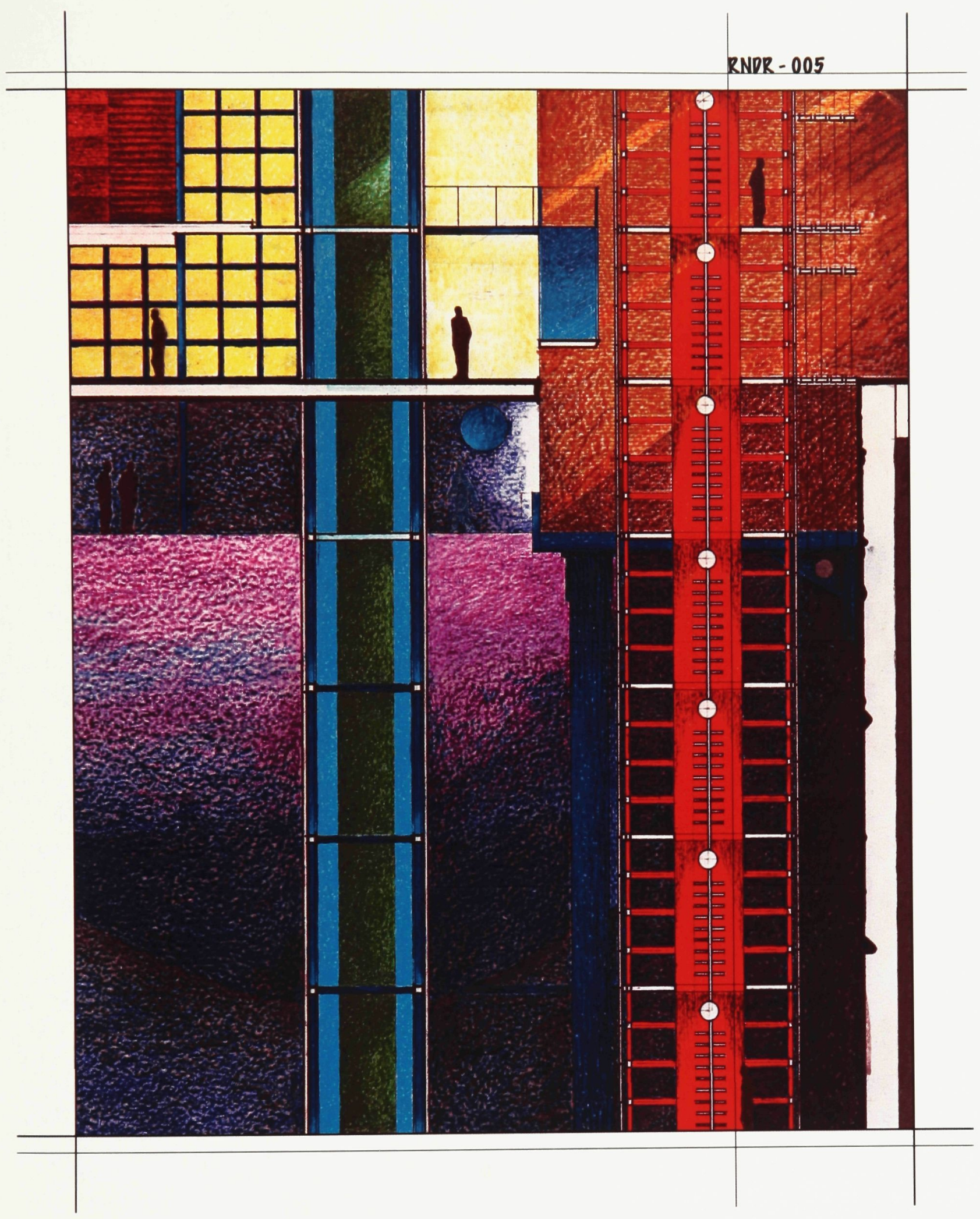




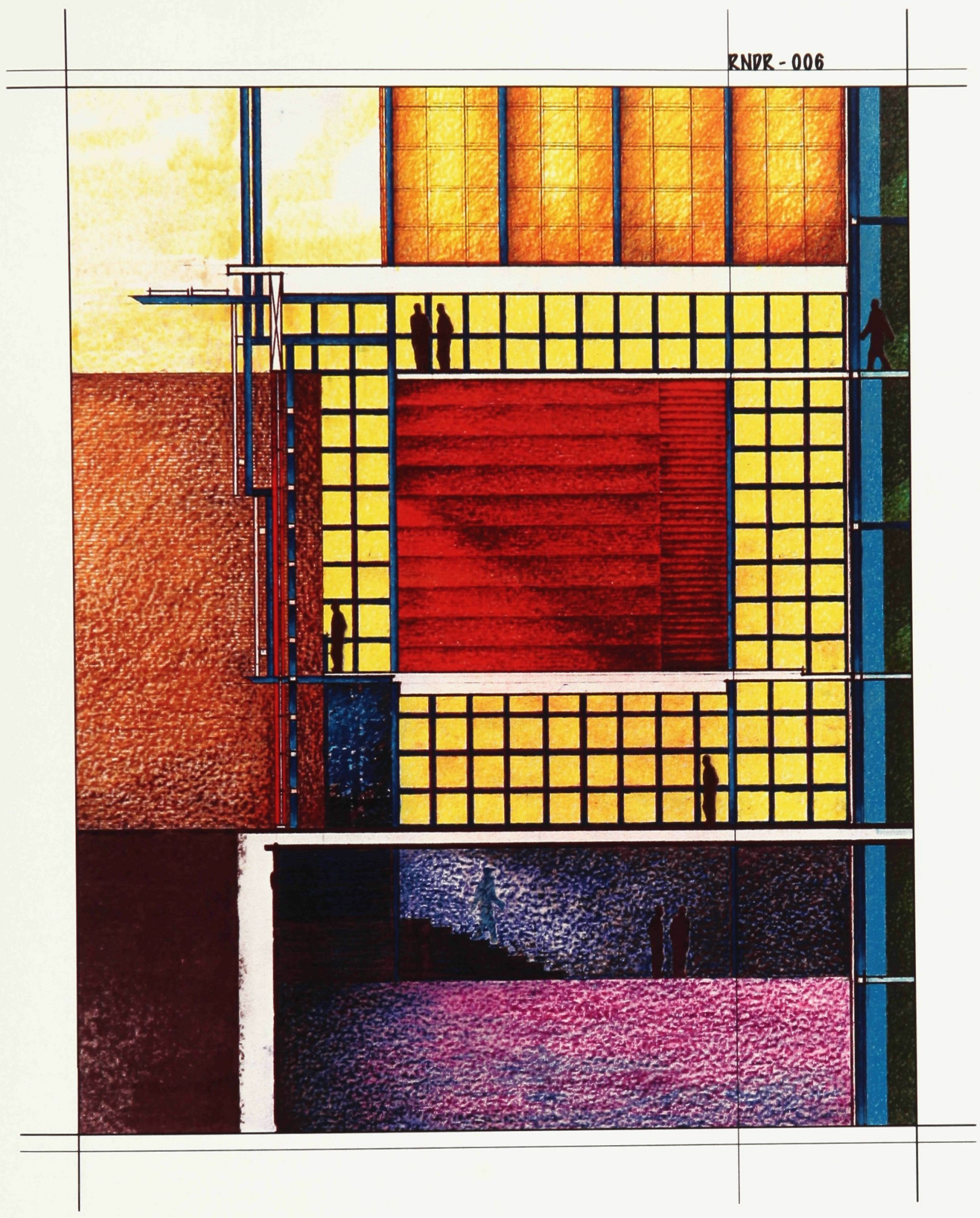




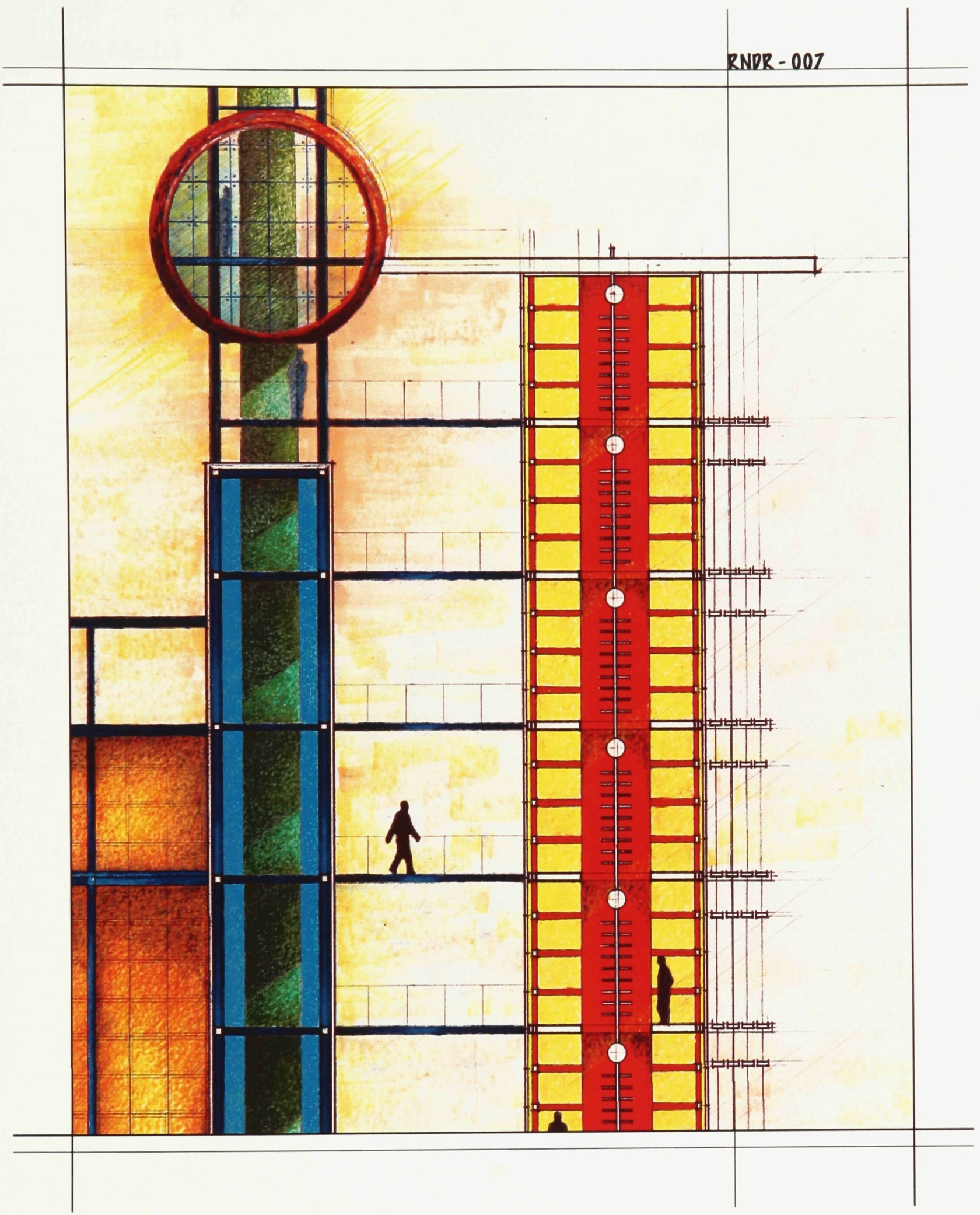


Massing Model 


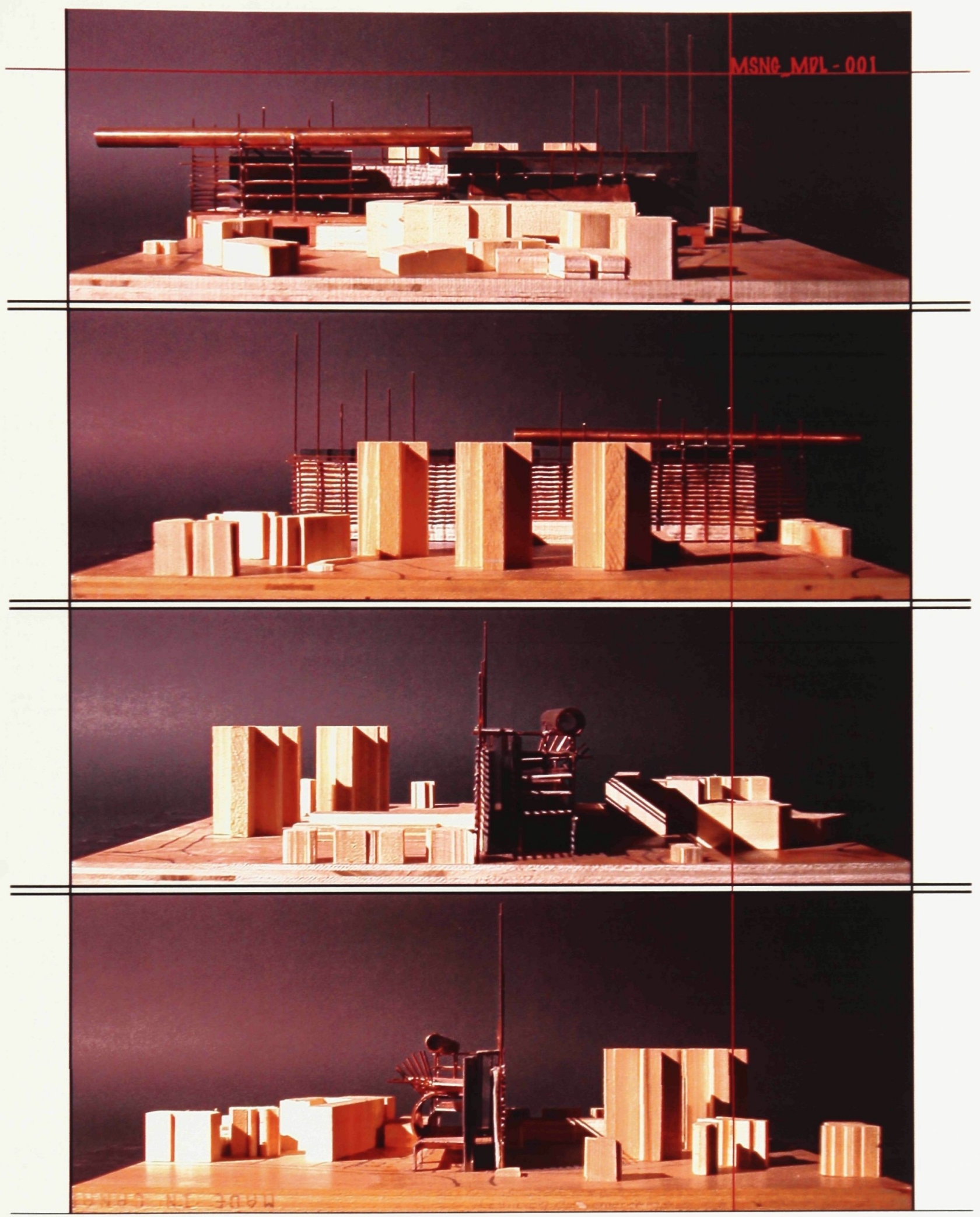




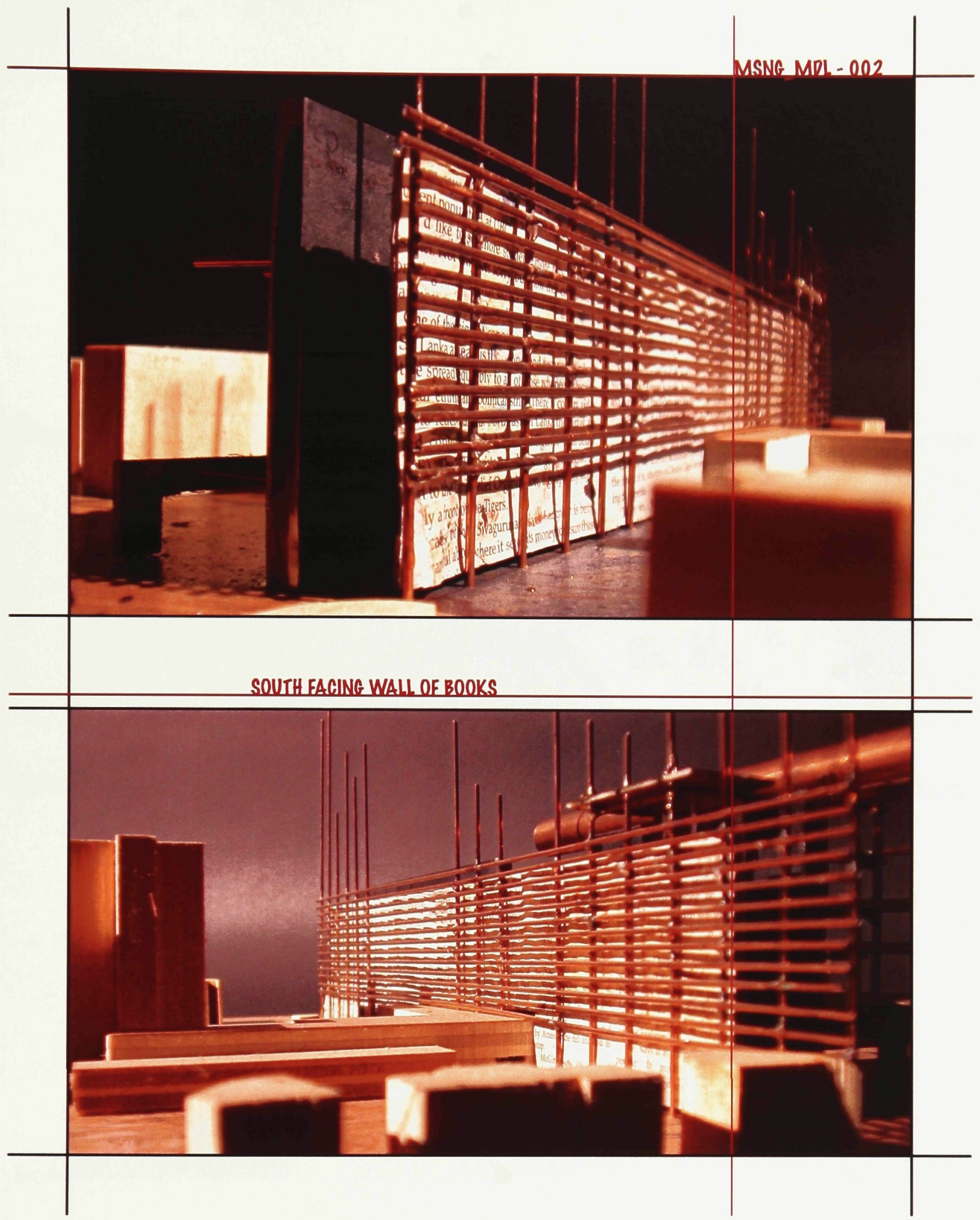




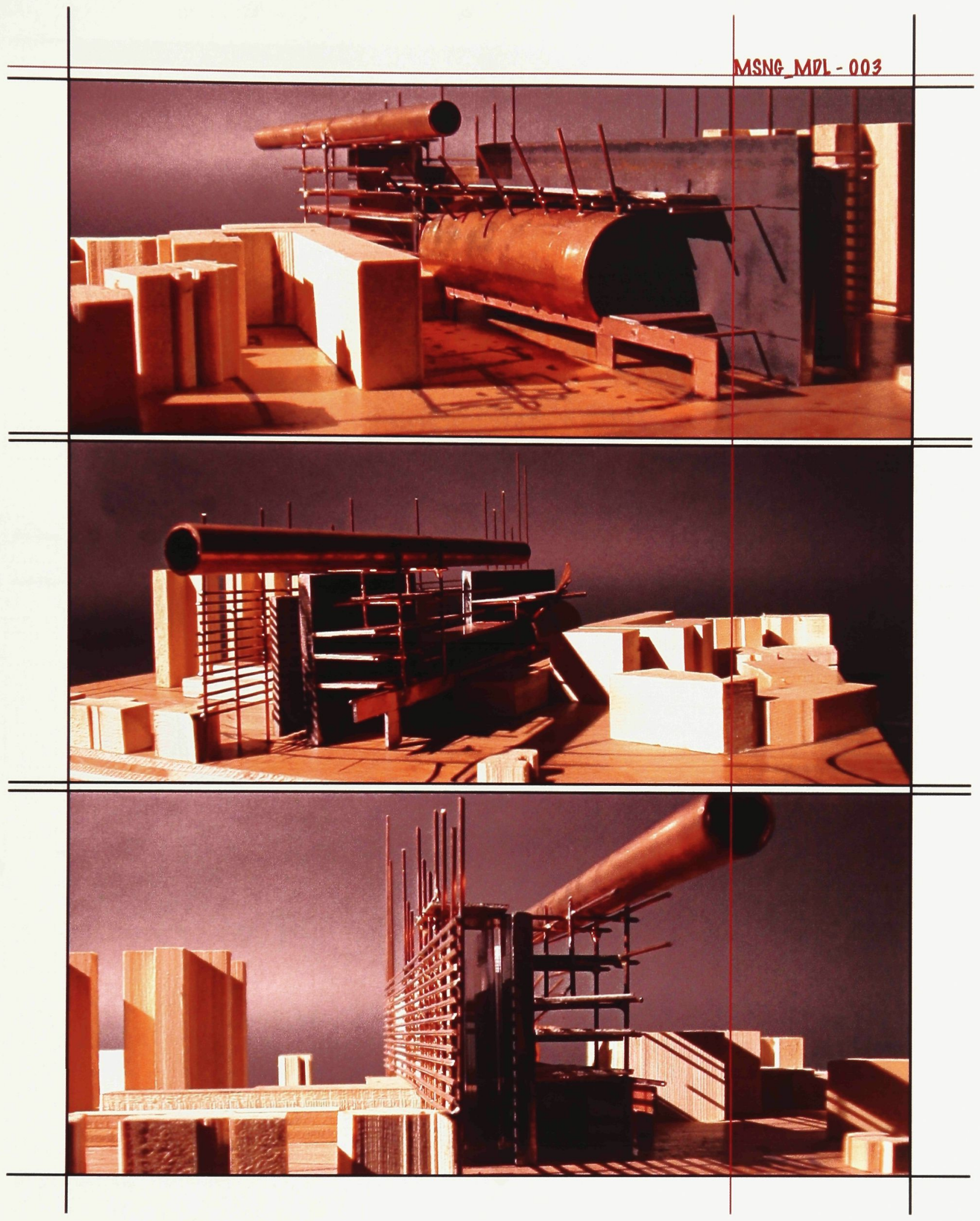




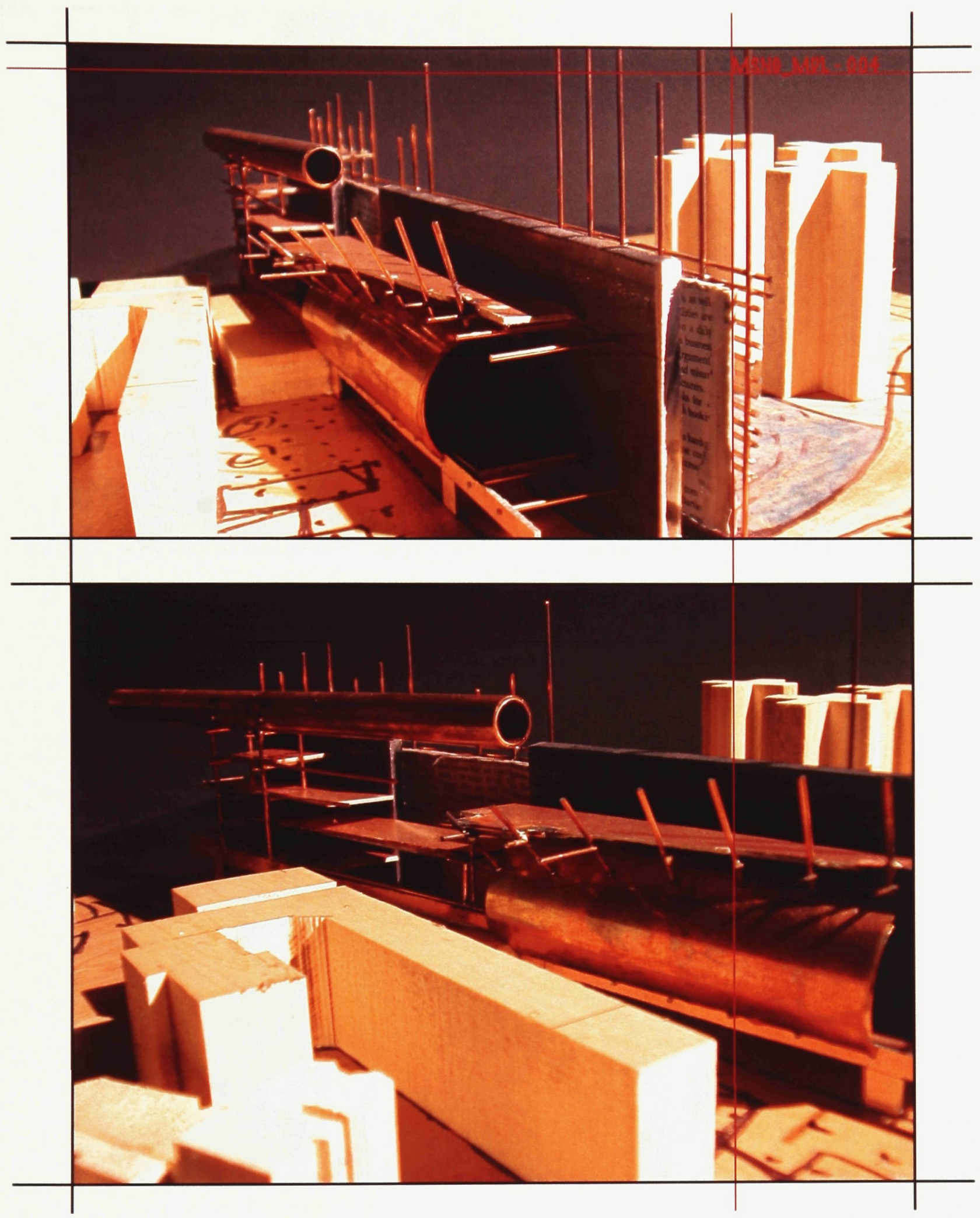




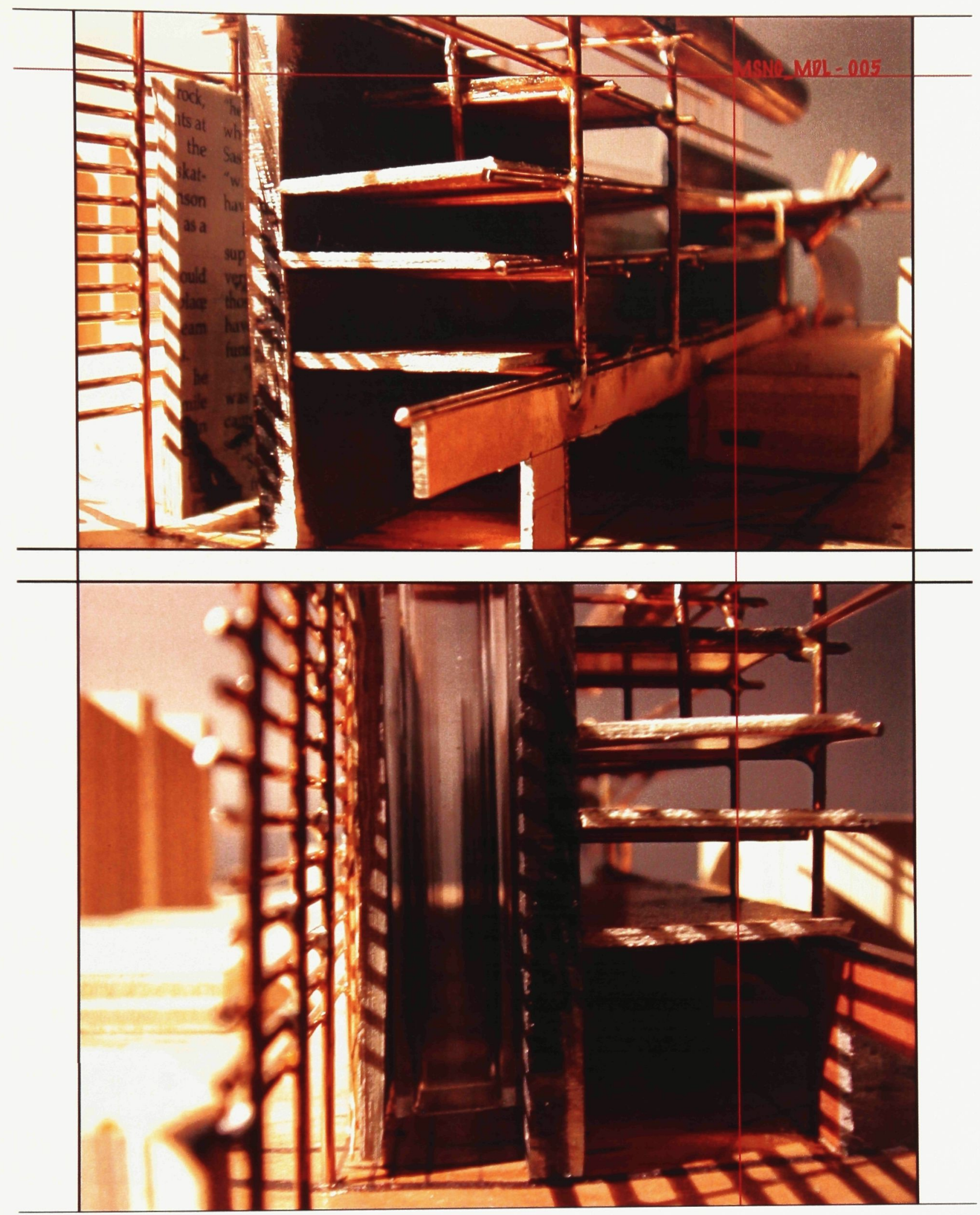




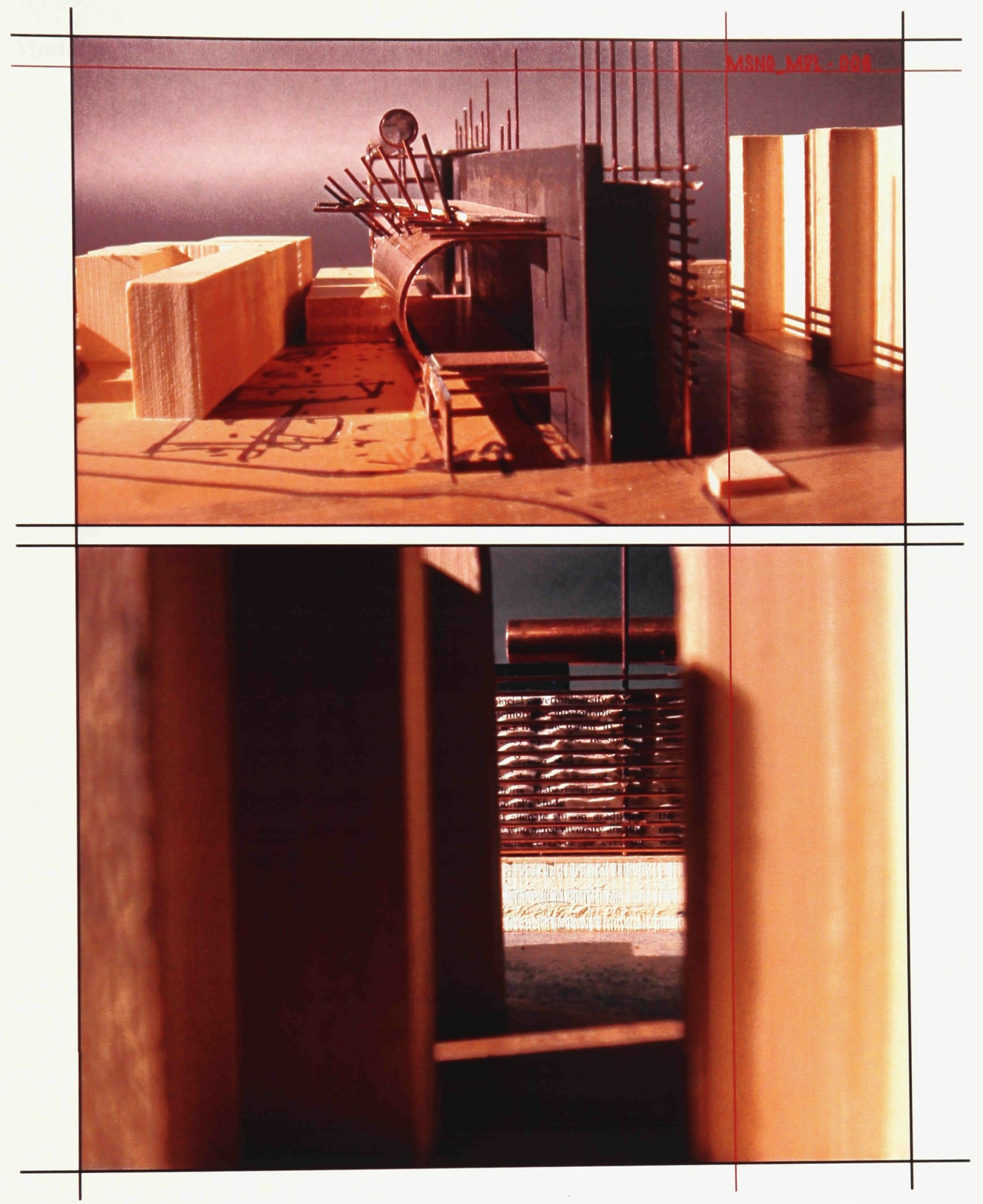


Model 


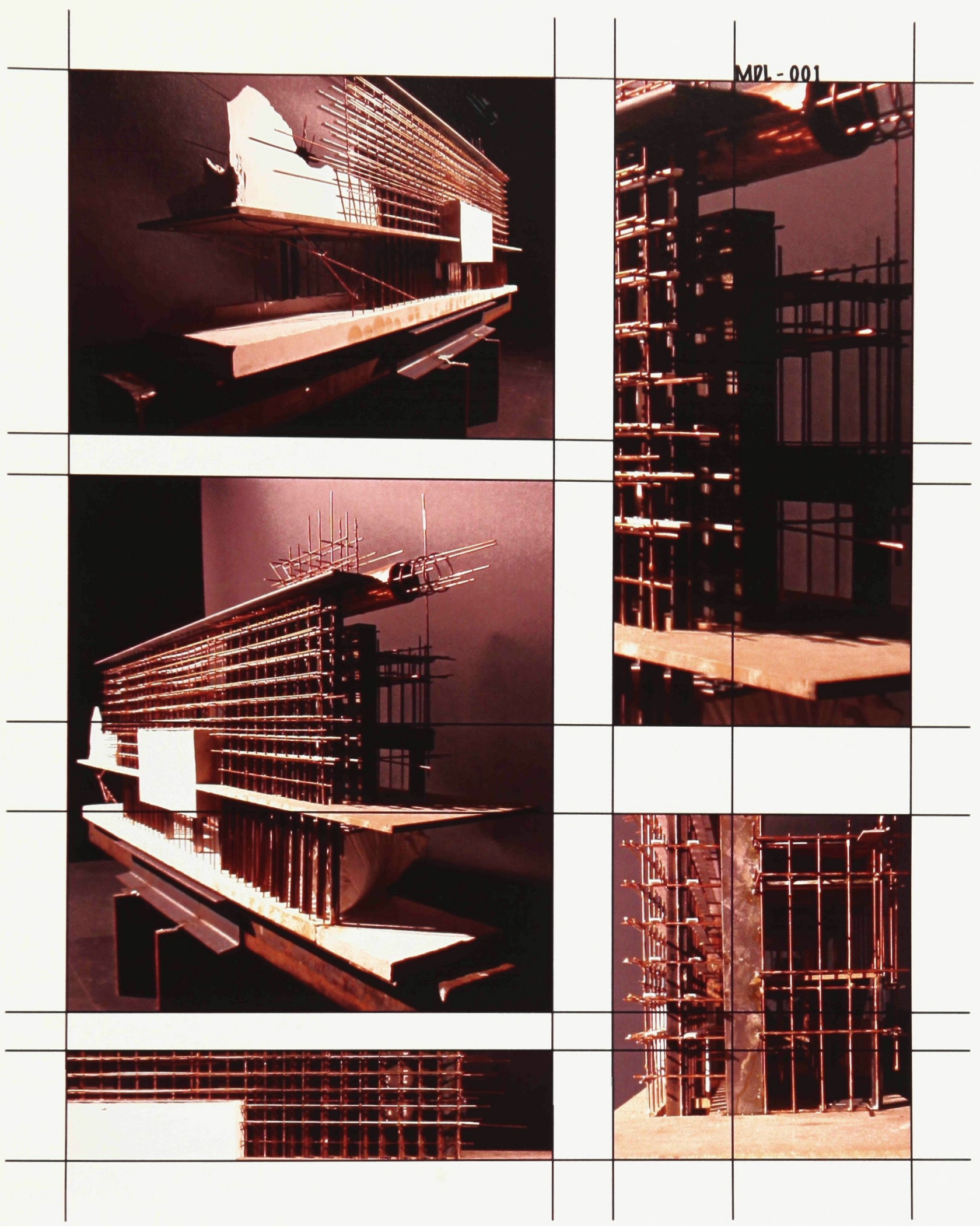




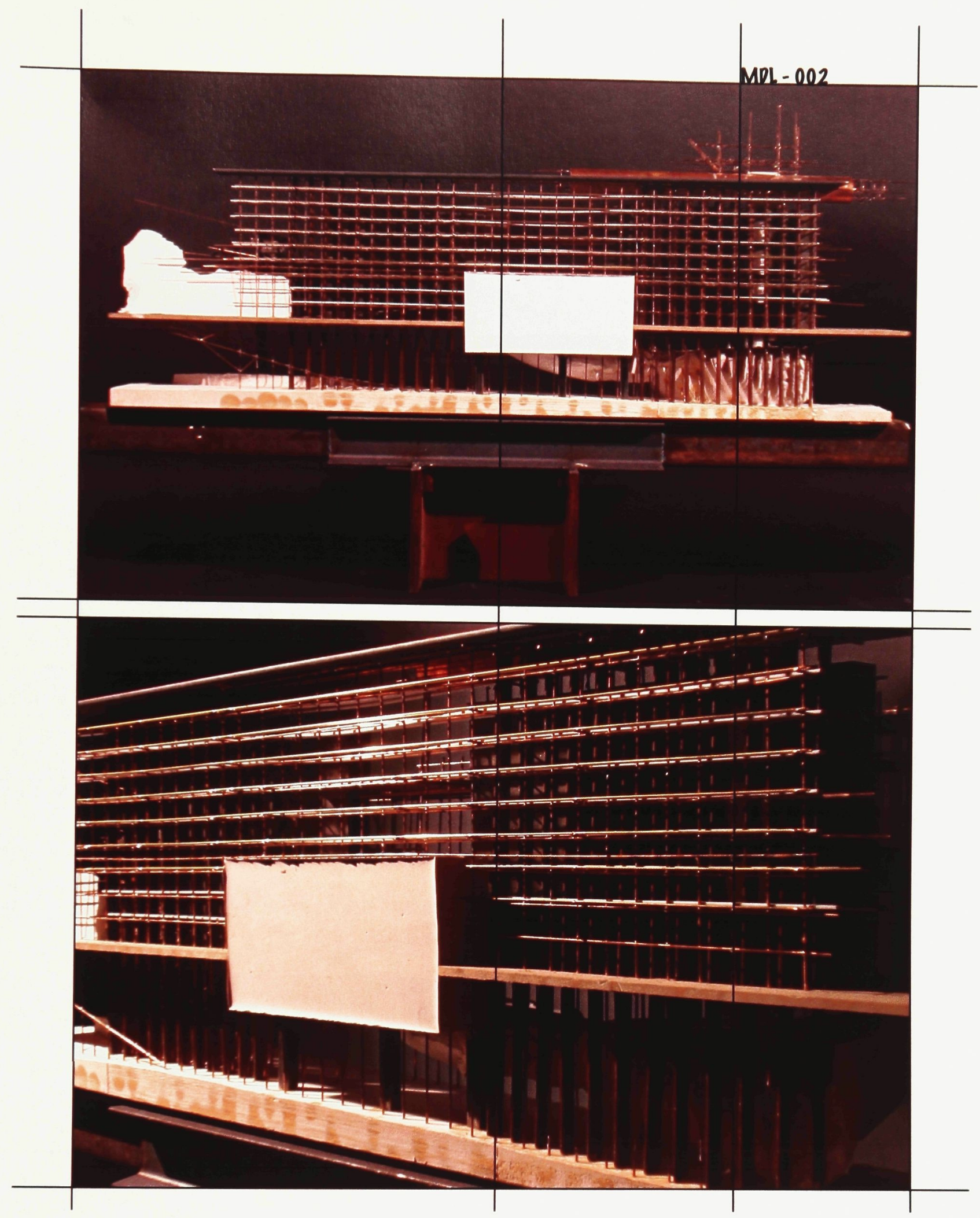




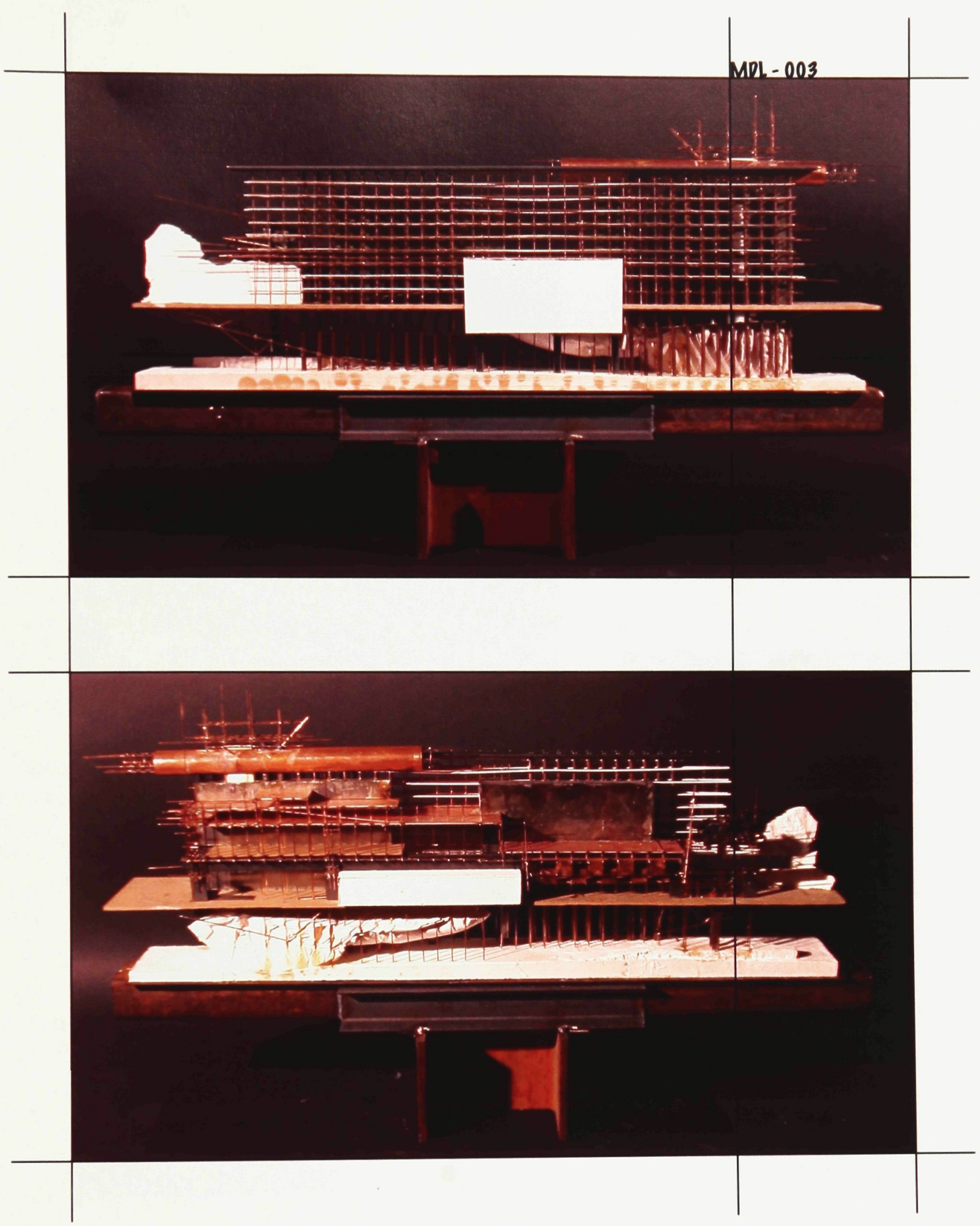




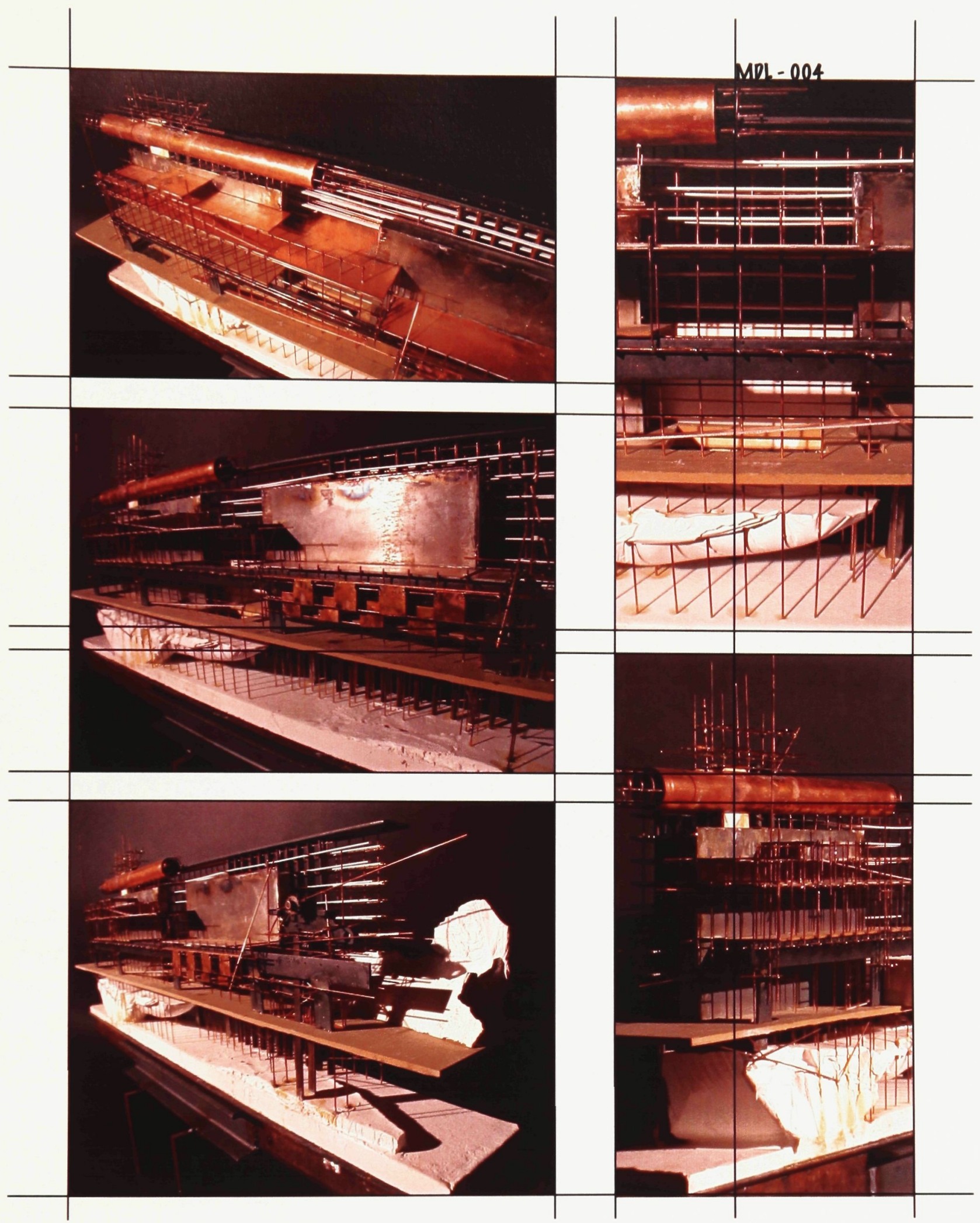




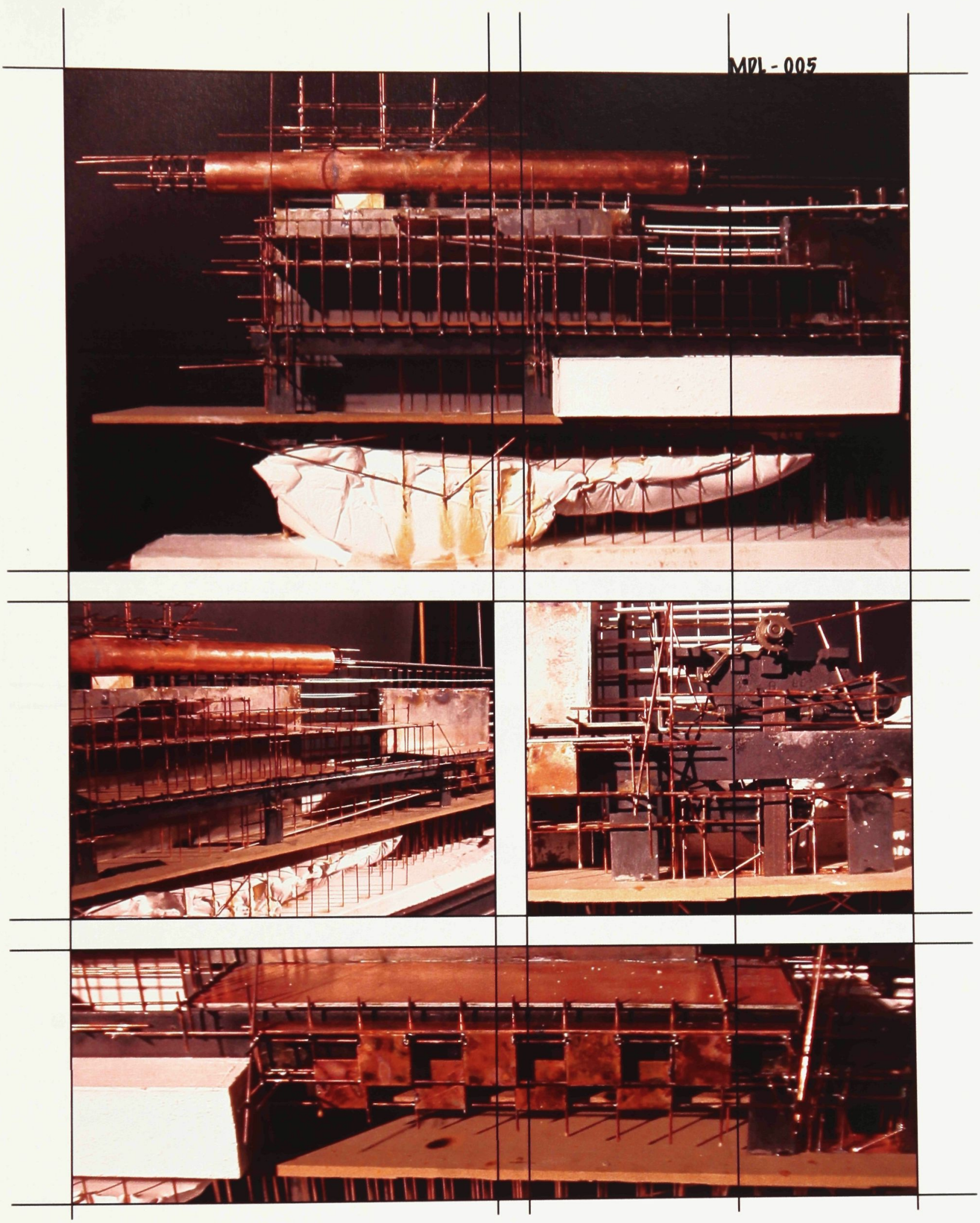




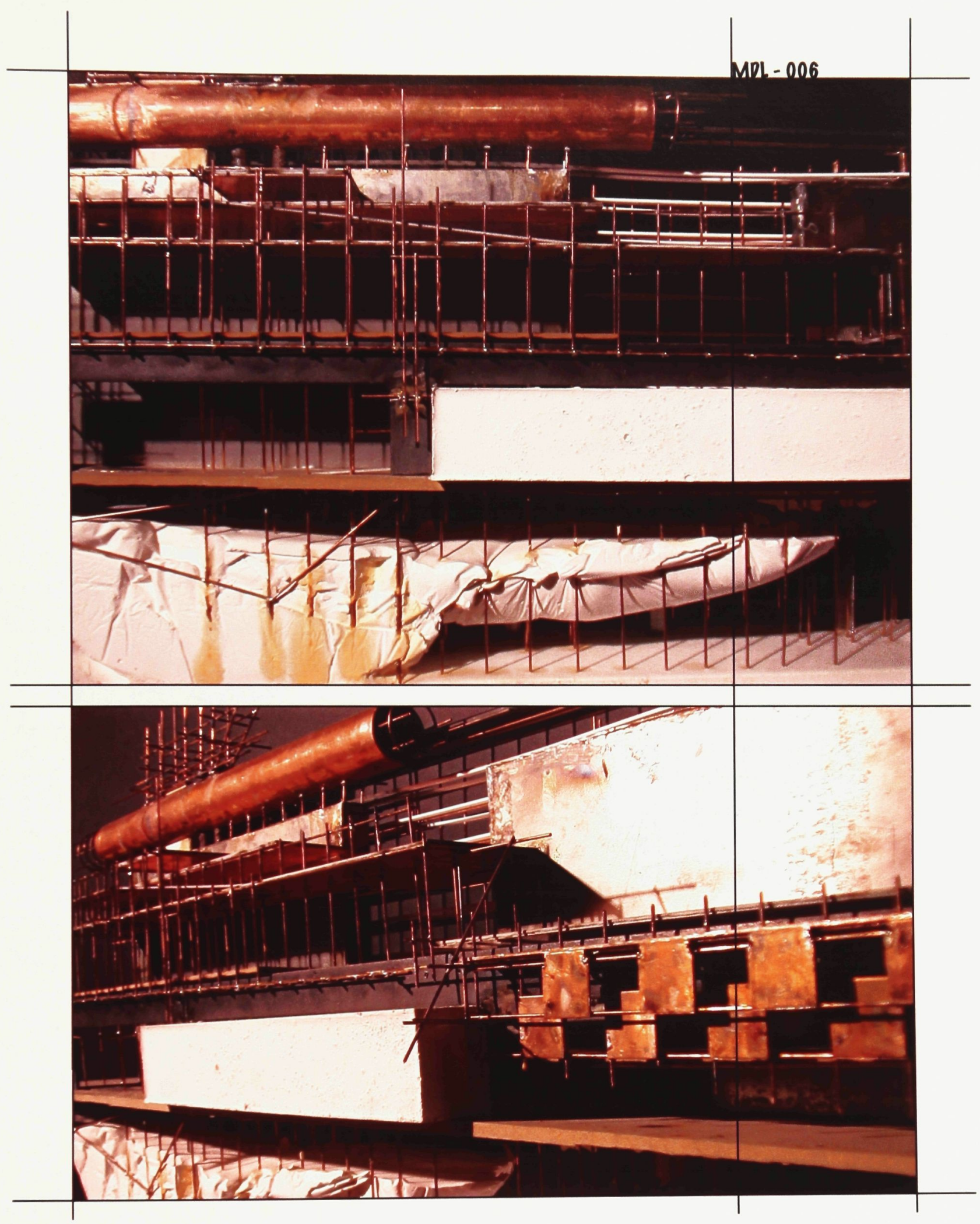




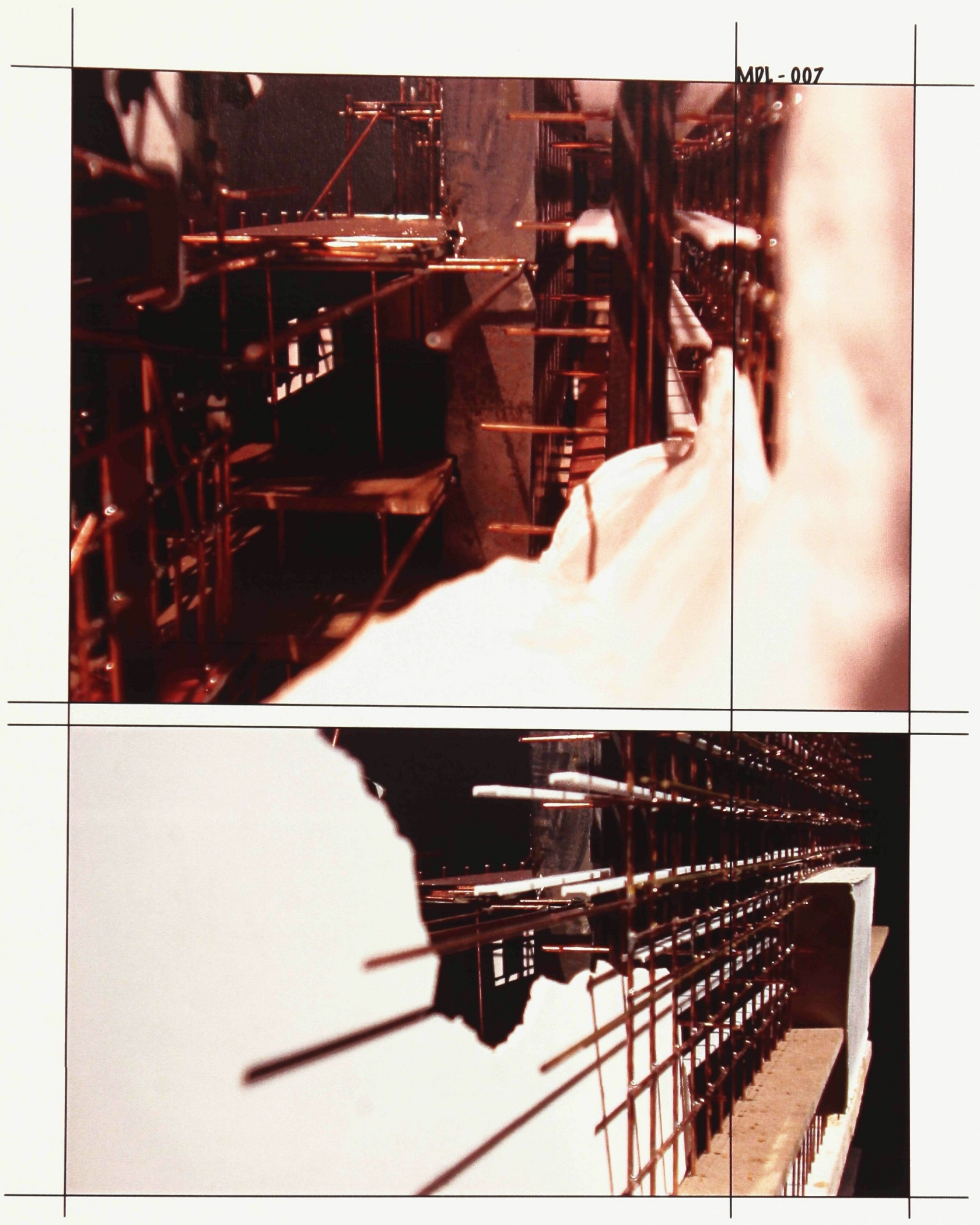




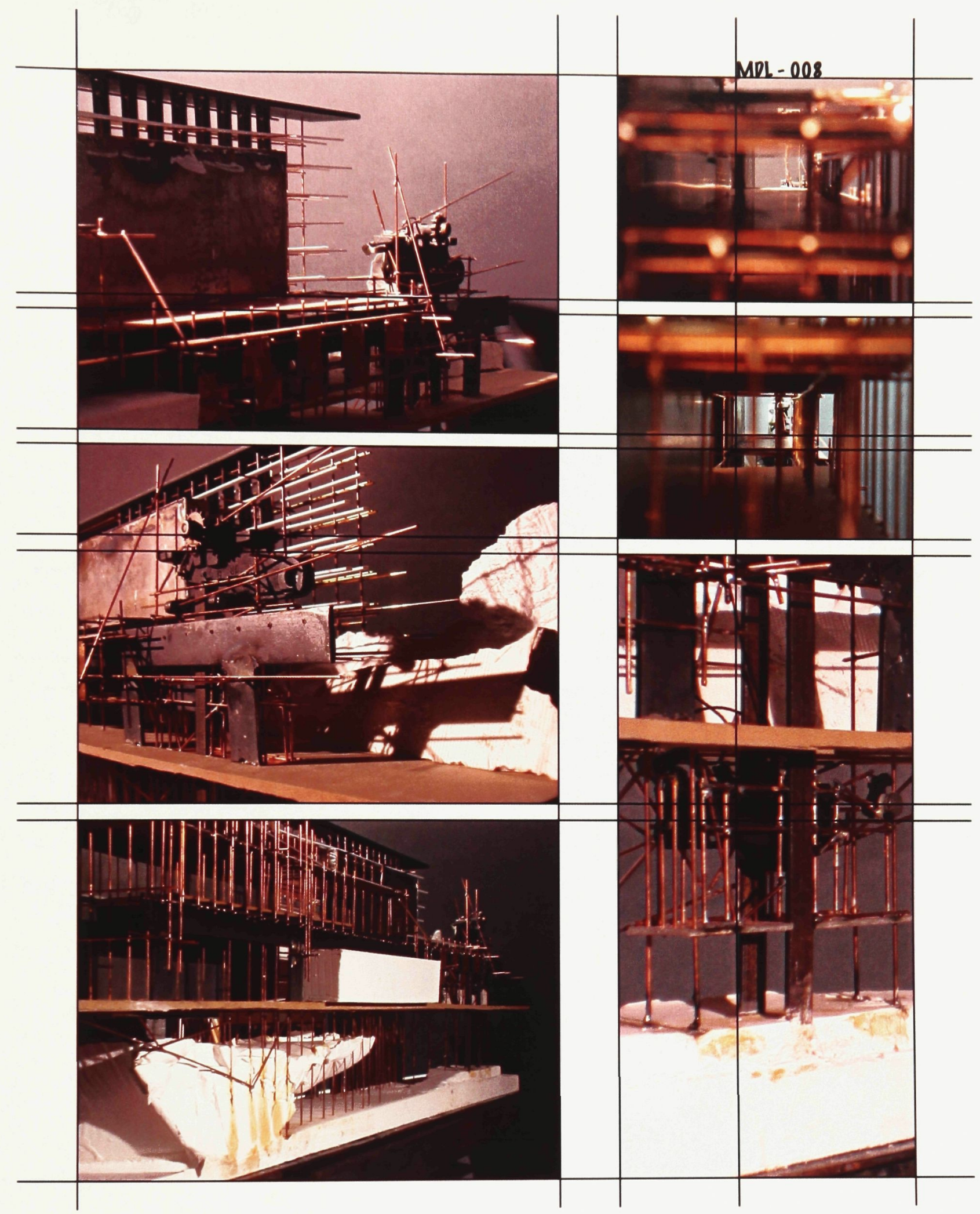




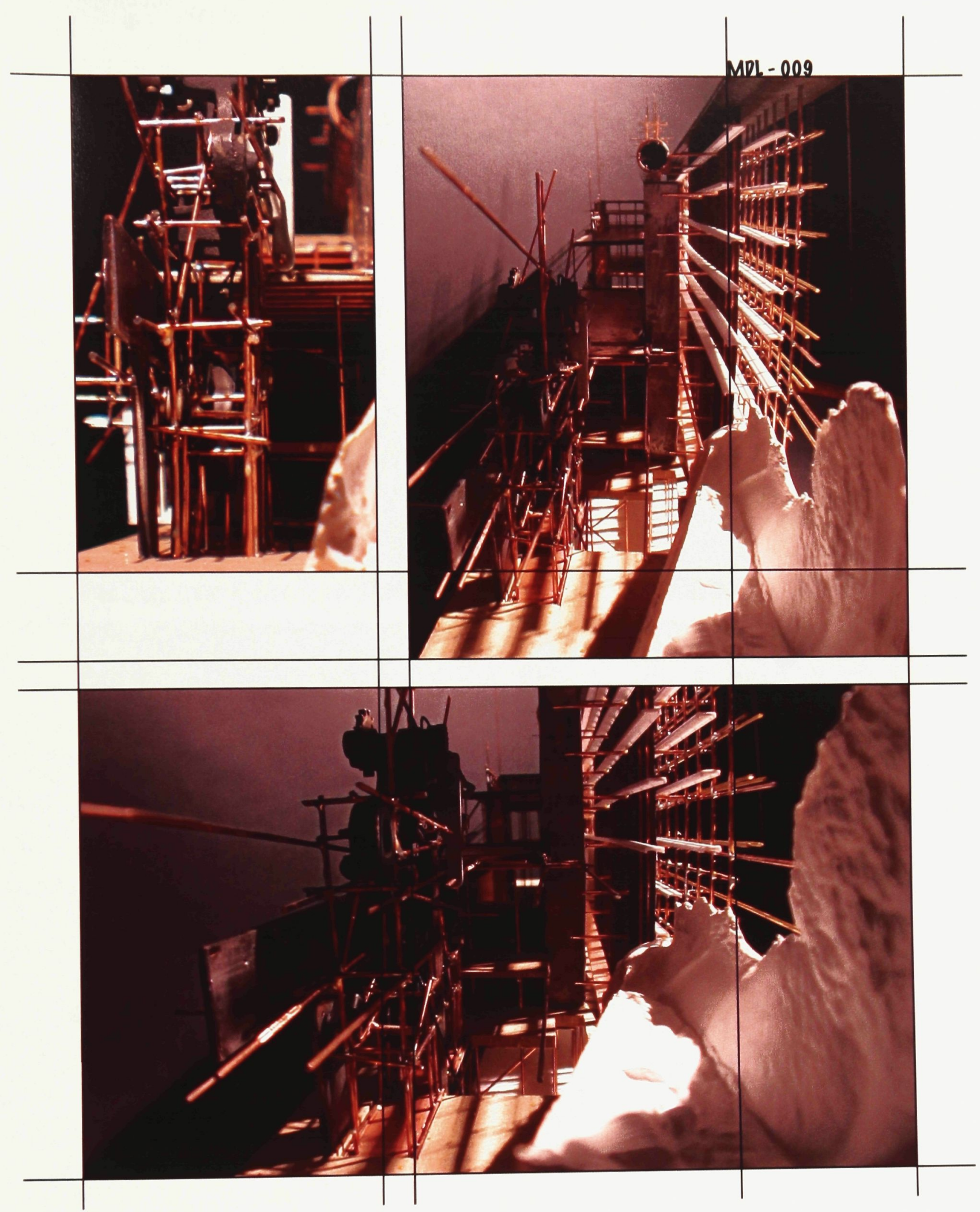




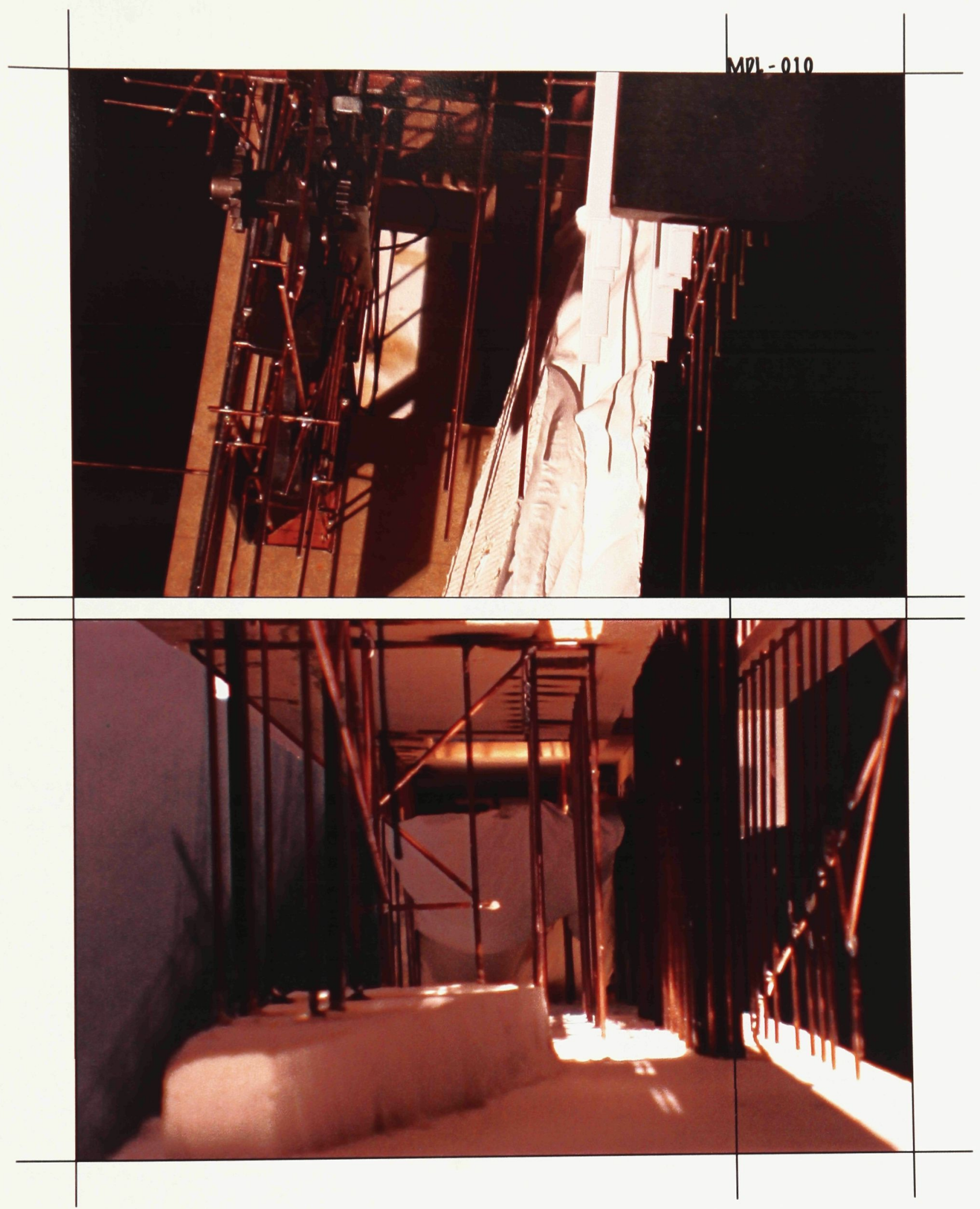




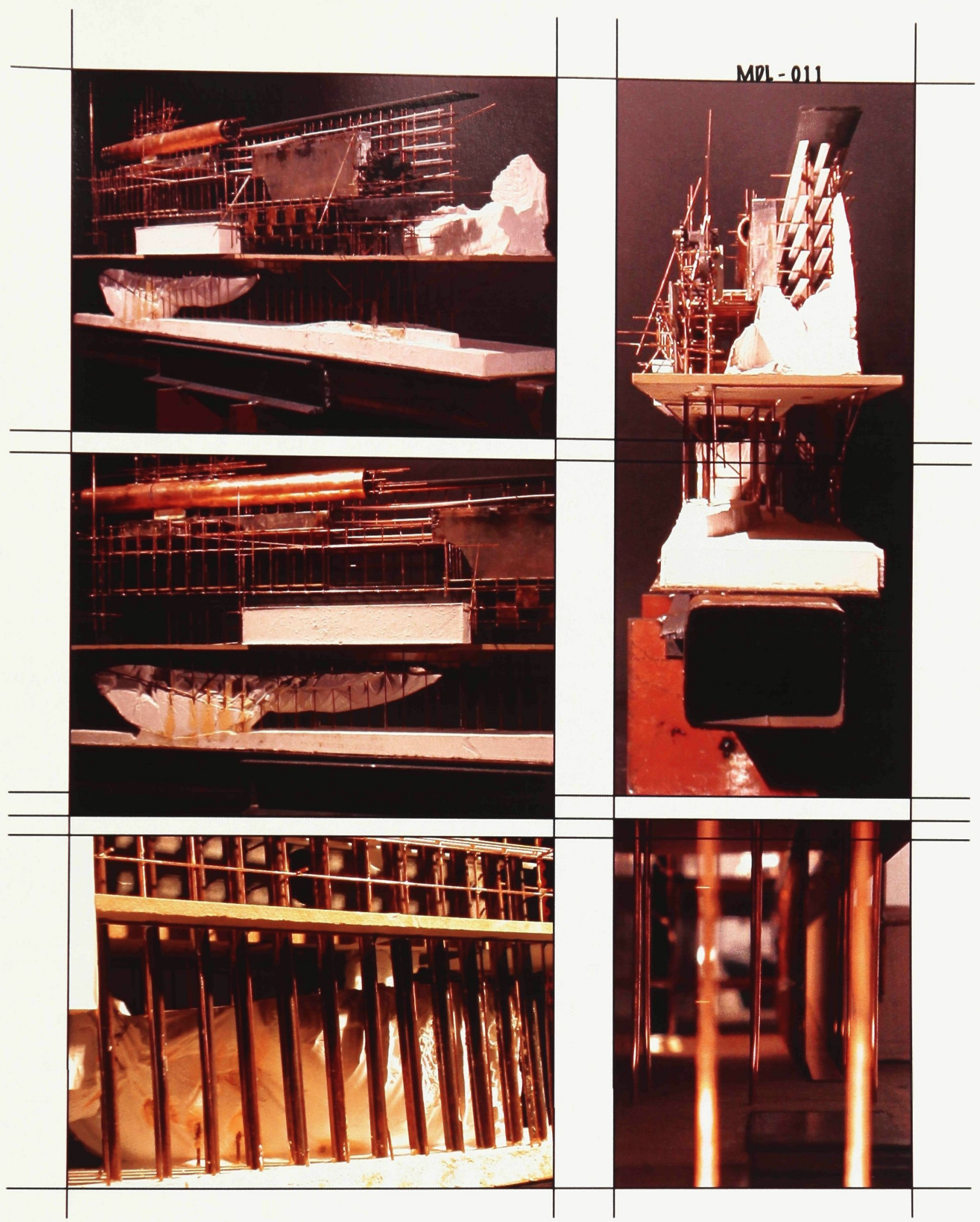




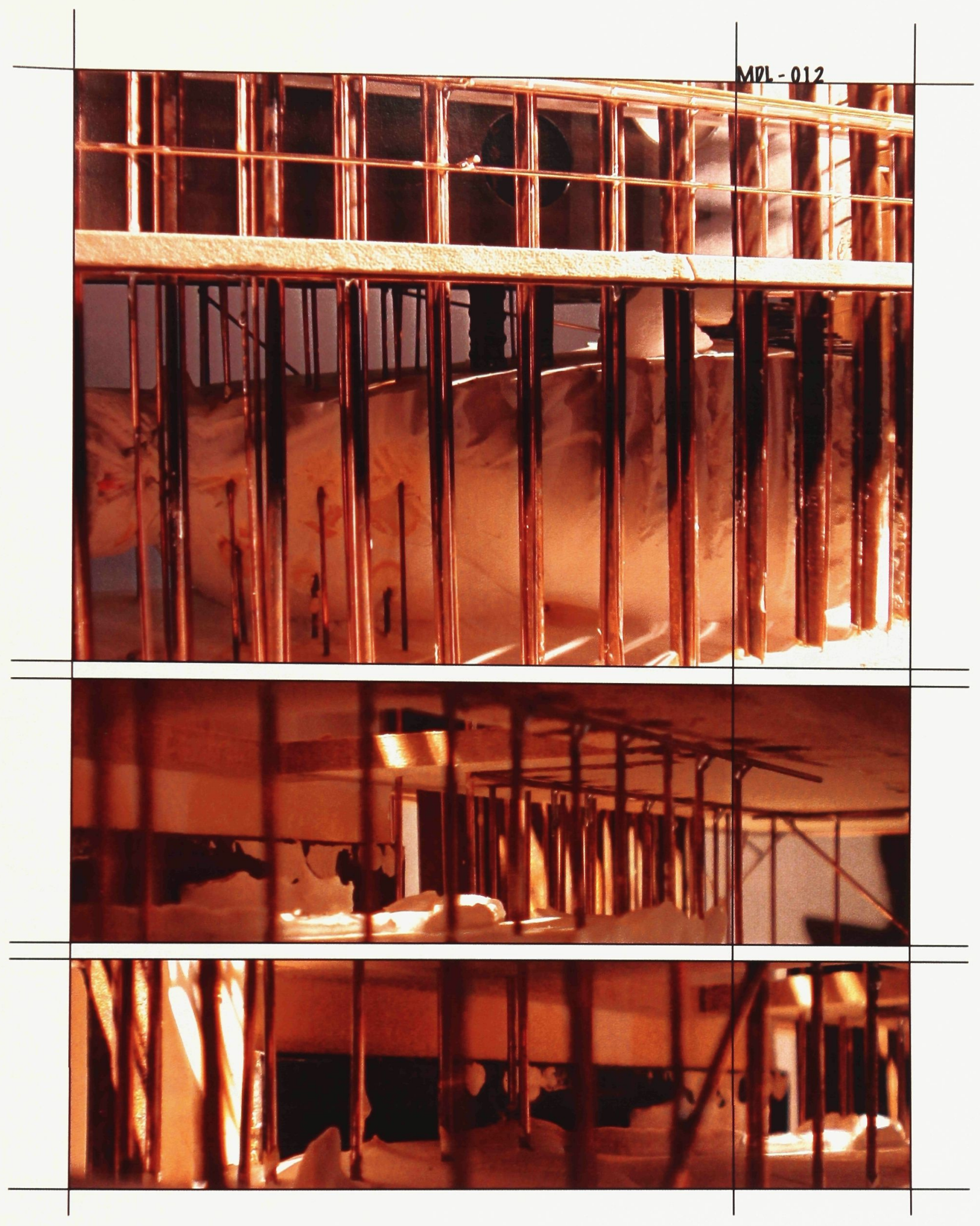




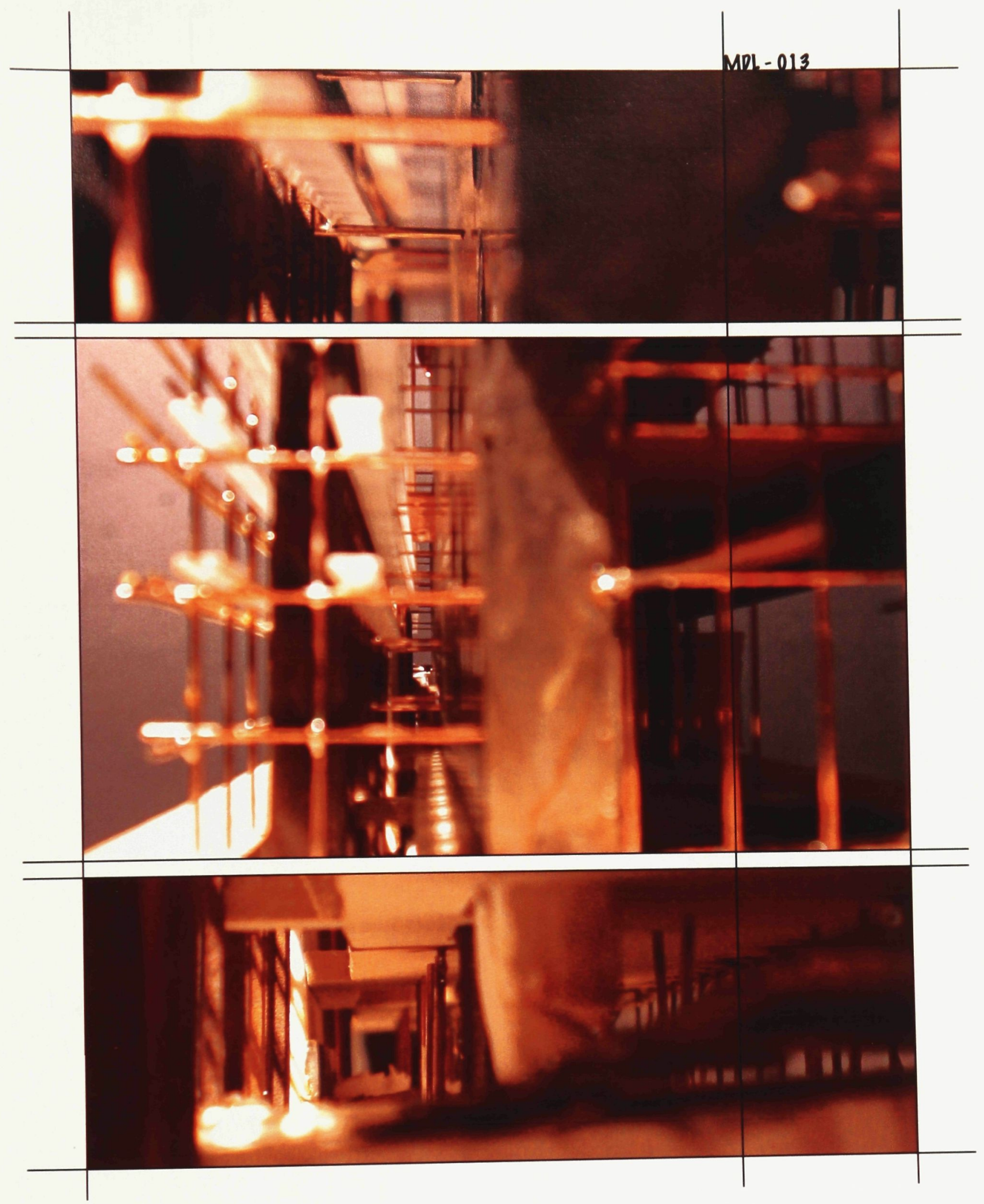




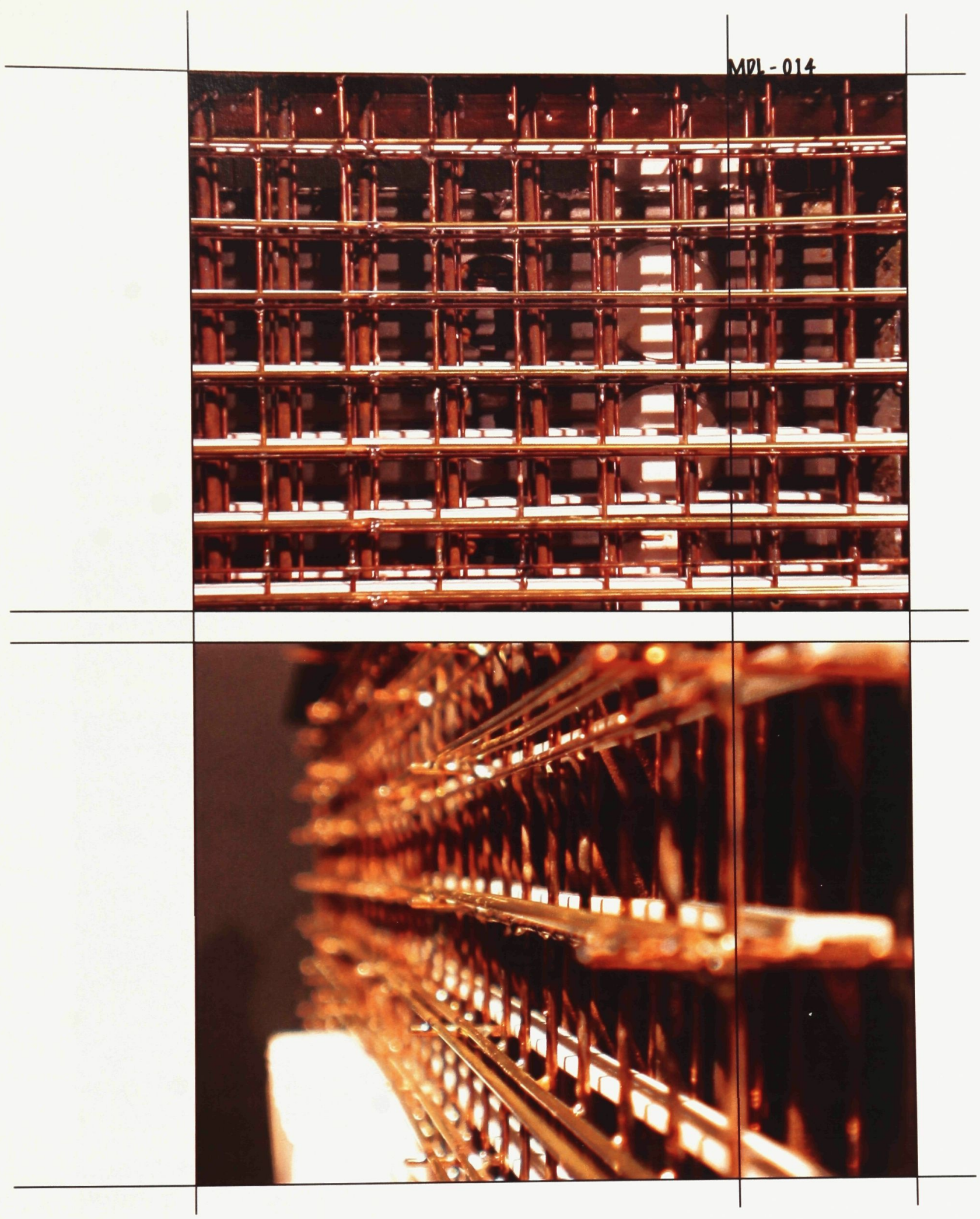




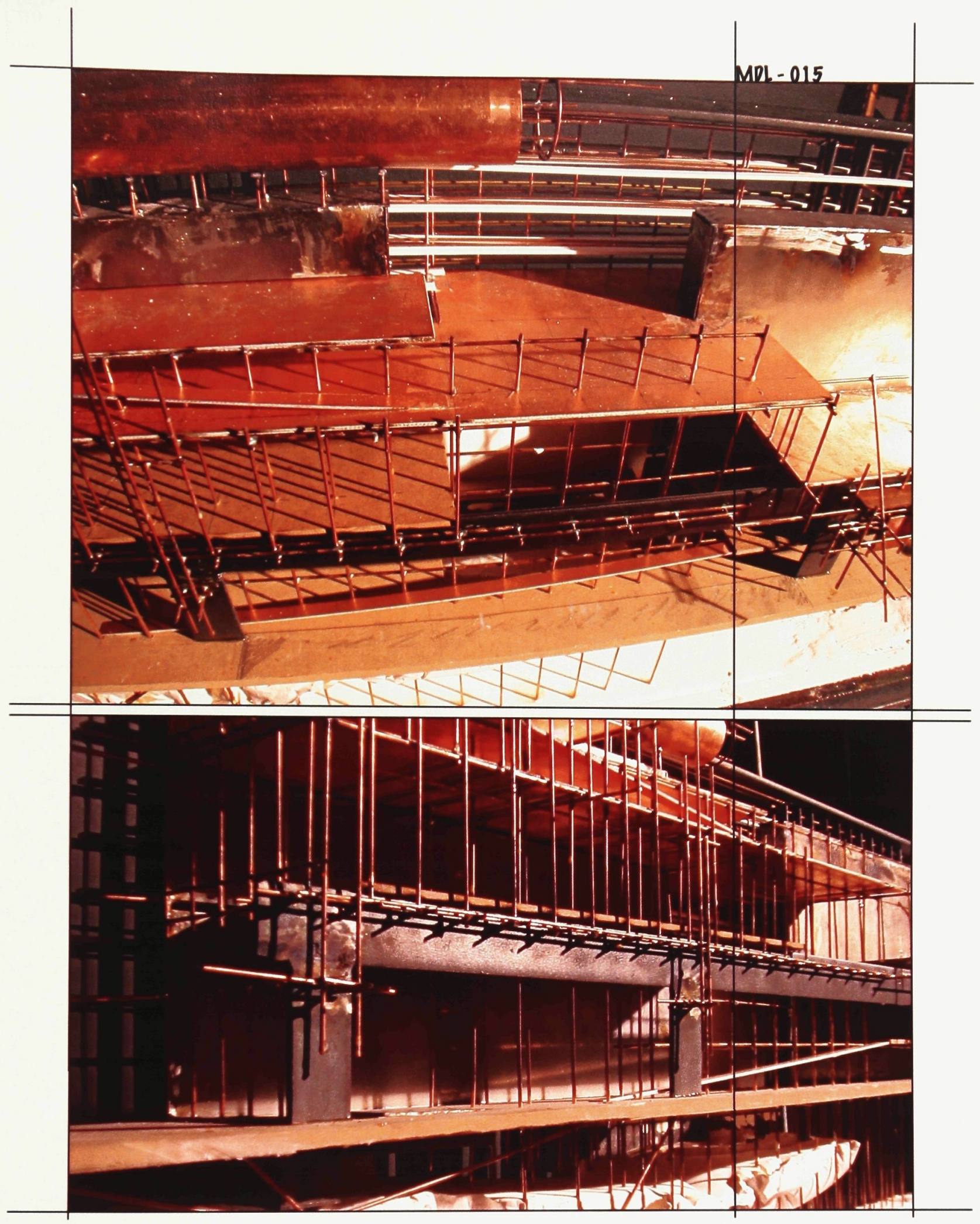




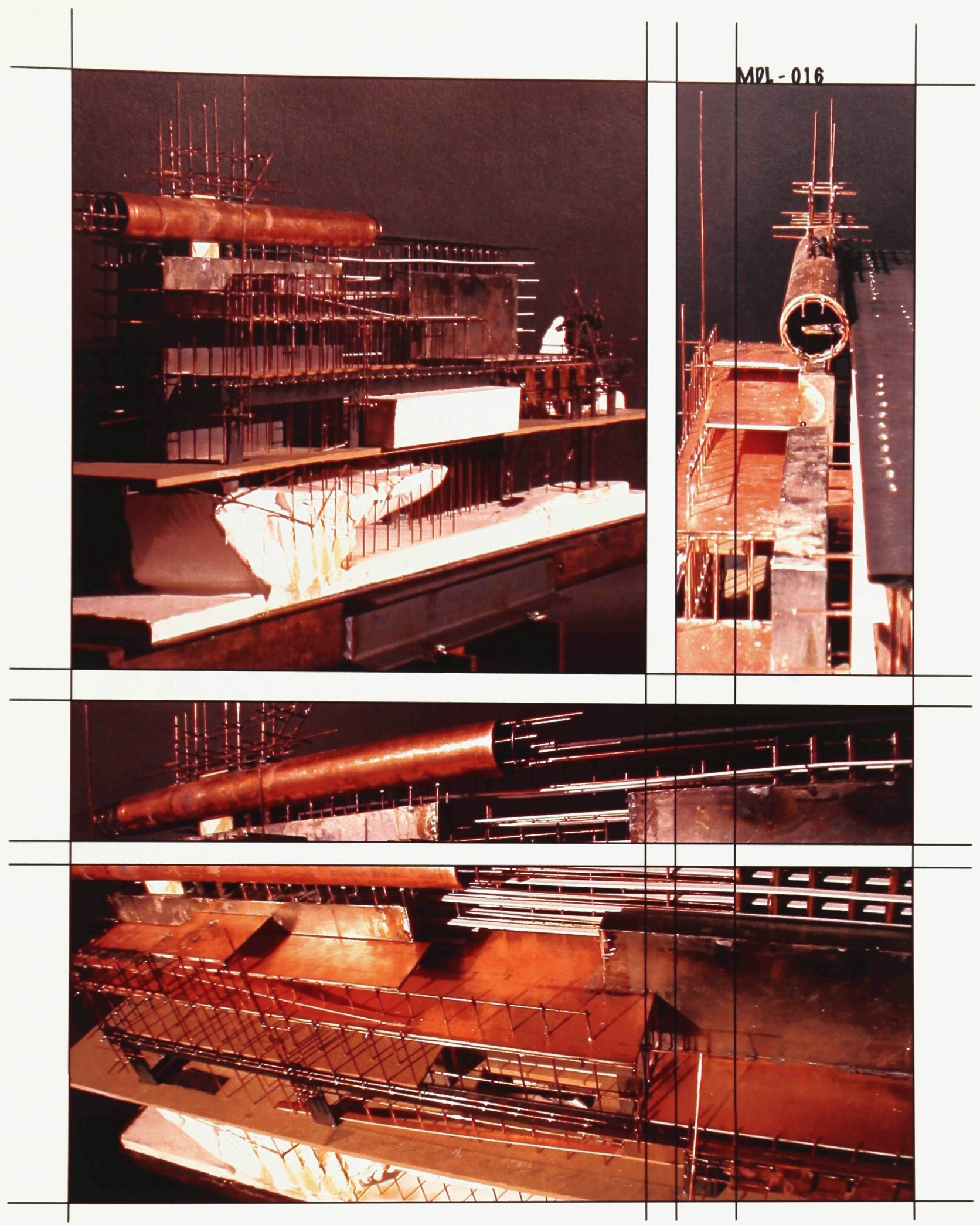




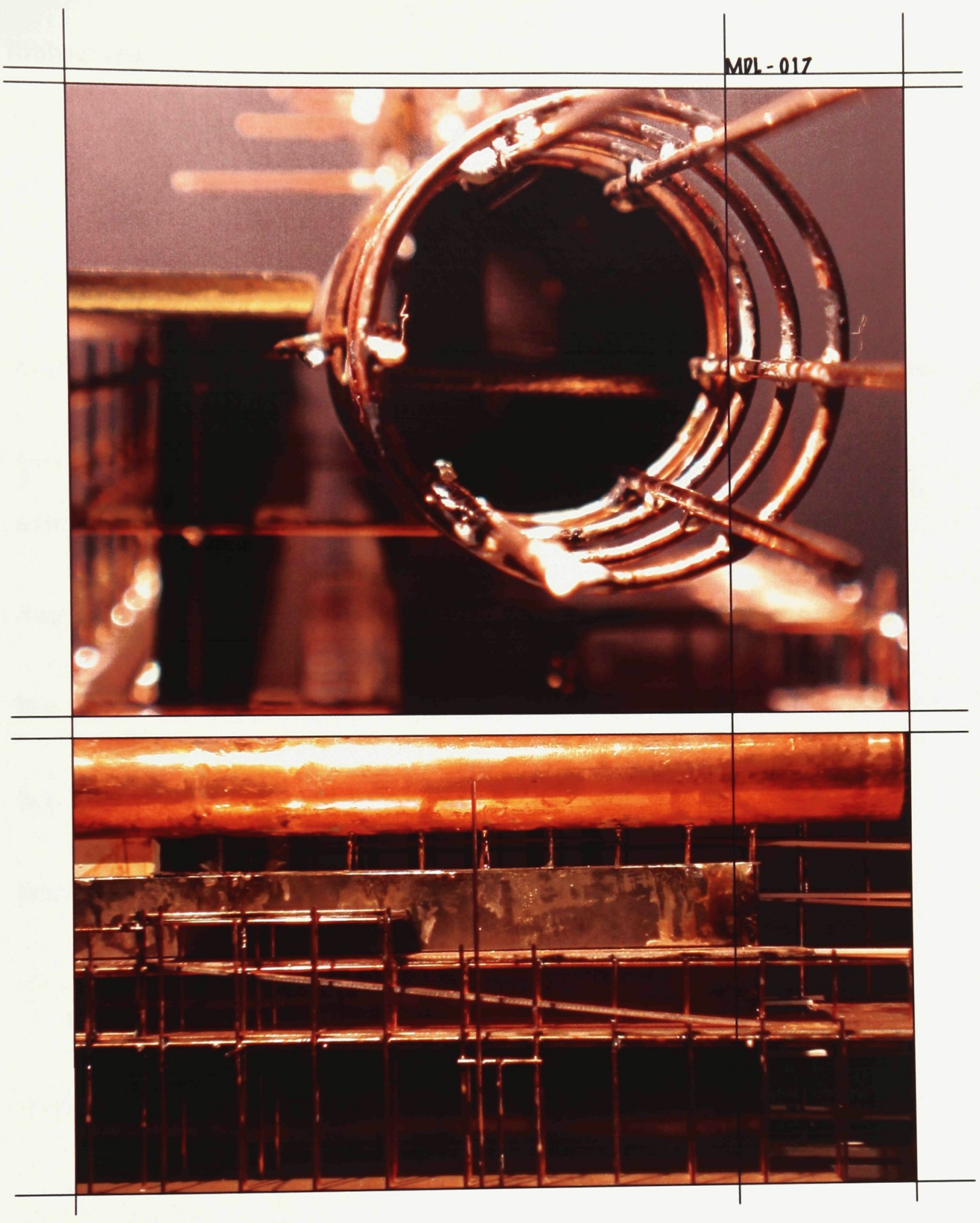




\section{Bibliography}

Asali, KJ. Jerusalem in History. England: Scorpion Publishing, 1989.

Ash Amin, Ash. "Regions Unbound: Towards a New Politics of Place" Geografiska Annaler B 86. 2004, 33-44.

Armstrong, Karen. Jerusalem: One City, Three Faiths. New York: Alfred A. Knopf, 1996.

Ashbee, C. R. Jerusalem: Records of the Pro Jerusalem Council 1918 - 1922. London: John Murray, 1921

Avi-Yonah, Michael. Jerusalem. Israel: Keter Publishing House, 1973.

Avni, Gideon. and Jon Seligman. The Temple Mount 1917-2001. Israel: Israel Antiquities Authority Publications, 2001.

Azar, George. Palestine: A Photographic Journey. California: University of California Press, 1991.

Ben-Arieh, Yehoshua. Jerusalem in the $19^{\text {th }}$ Century. New York: St. Martin's Press, Inc., 1984.

Ben-Dov, M.. "The Omayyad Structures Near the Temple Mount. Jerusalem: The Israel Exploration Society, 1971. Trans. Eretz-Israel 10 (1971)

Benvenisti, Meron. Jerusalem: The Torn City. Minneapolis: University of Minnesota Press, 1976.

Blenkinsopp J. The Bible, Archaeology and Politics; or The Empty Land Revisited. Journal for the Study of the Old Testament, 1 December 2002, Vol. 27, No. 2, $169-187(19)$

Blomley, Nicholas. Annals of the Association of American Geographers, "Law, Property, and the Geography of Violence: The Frontier, the Survey and the Grid". 93(1). 2003 121-141

Bowden, Brett. "In the Name of Progress and Peace: The "Standard of Civilization" and The Universalizing Project" Alternatives 29(1). 2004. 43-68.

Brawne, Michael. Libraries: Architecture and Equipment. New York:

Praeger Publishers, 1970. 
Brown, David. "On Narrative and Belonging" Paul Ricoeur and Narrative: Context and Contestation. Calgary: University of Calgary, 1997. 109-121.

Calhoun, Craig. "The Class Consciousness of Frequent Travellers: Towards a Critique of Actually Existing Cosmopolitianism" in Daniele Archibugi (ed.) Debating Cosmopolitics London: Verso, 2003, 86-116.

Chepesiuk, Ron. Libraries for Peace: Arafat sees education as the key to development. February 1998. http://www.towardfreedom.com/1998/feb98/librar.htm

Collins-Kreiner, N. and N. Kliot. Pilgrimage Tourism in the Holy Land: The Behavioural Characteristics of Christian Pilgrims. Netherlands: Kluwer Academic Publishers, GeoJournal 50: 55-67 (2000)

Comay, Joan. The Temple of Jerusalem. New York: Holt, Rinehart and Winston, 1975.

Dauenhauer, Bernard. "Ricoeur and Political Identity" Paul Ricoeur and Narrative: Context and Contestation. Calgary: University of Calgary, 1997. 129-141.

Debrix, Francois. "Tabloid Realism and the Revival of American Security Culture" Geopolitics 8(3). 2003. 151-190.

Dempsey, Gary T. Fool's Errands: America's Recent Encounters with Nation-building. Mediterranean Quarterly. 12:1, 2001.

Dumper, Michael. The Politics of Sacred Space: The Old City of Jerusalem in the Middle East Conflict. London: Lynne Rienner Publishers, 2002.

Dumper, Michael. The Politics of Jerusalem Since 1967. New York:

Columbia University Press, 1997.

Eco, Umberto. "Interpretation and History." Interpretation and Overinterpretation.

Ed. Stefan Collini. Cambridge: Cambridge UP, 1992. 30

Egyptian State Information Service. Bibliotheca Alexandrina: The Norwegian-Egyptian Connection. October 20, 2004. [Online], Available from http://www.sis.gov.eg (Accessed November 8, 2004)

El-Haj, Nadia Abu. Facts on the Ground: Archaeological Practice and Territorial Self -Fashioning in Israeli Society. Chicago: The University of Chicago Press, 2001.

Elon, Amos. Jerusalem: City of Mirrors. London: Little, Brown and Company, 1989.

El Sahn, Marwa. World Library and Information Congress: $69^{\text {th }}$ IFLA General Conference and Council. August 2003, Berlin. 1-9 
Epstein, Alek D. and Nina G. Kheimets. Looking for Pontius Pilate's Footprints Near the Western Wall: Russian Jewish Tourists in Jerusalem. USA: Tourism, Culture and Communication, Vol. 3 37-56. (2001)

Etzioni, A. A Self-Restrained Approach to Nation-Building by Foreign Powers. Blackwell Publishing: International Affairs, Vol. 80, no. 1 Pg. 1-17. January 2004

Frampton, Kenneth. "Towards a Critical Regionalism: Six Points for an Architecture of Resistance" Labour Work and Architecture. New York: Phaidon, 2002. $76-89$.

Geva, Hillel. Ancient Jerusalem Revealed. Israel: Israel Exploration Society, 1994.

Gibson, Shimon. and David M. Jacobson. Below the Temple Mount in Jerusalem: A Sourcebook on Cisterns, Subterranean Chambers and Conduits of the Haram al -Sharif. England: Archaeological and Historical Associates, 1996.

Golden, D. The Museum of the Jewish Diaspora Tells a Story: The Tourist Image "Myths and Myth Making in Tourism". Chichester: John Wiley and Sons, 1996. 223-250.

Herzog, Ze'ev. Archaeology of the City: Urban Planning in Ancient Israel and its Social Implications. Israel: Emery and Claire Yass Archaeology Press, 1997.

Holt, Raymond. Planning Library Buildings and Facilities: From Concept to Completion. London: The Scarecrow Press, 1989.

Holum, Kenneth G., Robert L. Hohlfelder, Robert J. Bull, and Avner Raban. King Herod's Dream: Caesarea on the Sea. New York: W.W. Norton and Company, 1988.

Kaplan, Robert D. Supremacy by stealth: Ten Rules For Managing the World. Atlantic Monthly. July-Aug. 2003.

Karatani, Kojin. Architecture as Metaphor: Language, Number, Money. Trans. Sabu Kohso. Ed. Michael Speaks. Cambridge, MA.: MIT Press, 1995. 4 - 57.

Kenny, Janice. National Library of Australia: History and Collections. Canberra: National Library of Australia, 1984.

Kenyon, Kathleen M. Digging up Jerusalem. London: Ernest Benn Limited, 1974.

Kroyanker, David. Jerusalem Architecture. New York: Vendome Press, 1994.

Leach, Neil. Belonging. AA Files 49. 76 
Livesey, Graham. "The Role of Figure in Metaphor, Narrative and Architecture" Paul Ricoeur and Narrative: Context and Contestation. Calgary: University of Calgary, 1997. $25-35$.

Maraini, Fosco. Jerusalem: Rock of Ages. London: Hamish Hamilton, 1969.

Martin, Ernest L. The Temples that Jerusalem Forgot. Portland: ASK Publications, 2000.

Massey, Doreen. Geografiska Annaler B, "Geographies of Responsibility". 93(1). $20035-18$

Mazar, B. The Excavations in the Old City of Jerusalem Near the Temple Mount. Jerusalem: The Israel Exploration Society, 1971. Trans. Eretz-Israel 10 (1971)

Morny, Joy. "Introduction" Paul Ricoeur and Narrative: Context and Contestation. Calgary: University of Calgary, 1997.

Moshe, Safdie. Jerusalem: the future of the past. Boston: Houghton Mifflin, 1989.

National Libraries: Their Problems and Prospects. "Symposium on National Libraries in Europe. Paris: UNESCO, 1960.

Ollenburger B.C. Review Essay: The History of Israel Contested and Revised. Modern Theology, October 2000, Vol. 16, No. 4, 529-540(12)

Blackwell Publishing

Pal Kolsto, "Nation-building and social integration theory, in Pal Kolsto, ed., Nation-building and ethnic integration in post-Soviet societies: an investigation of Latvia and Kazakstan (Boulder, CO: Westview, 1999).

Parenti, Michael. "Prologue: Against the Mainstream" History as Mystery. San Francisco: City Lights Books, 1999.

Parrot, Andre. The Temple of Jerusalem. London: 1957.

Parsons, Edward Alexander. The Alexandrian Library: Glory of the Hellenic World. New York: Elsevier Publishing Company. 1967.

Popke, Jeff. Progress in Human Geography, "Poststructuralist Ethics: Subjectivity Responsibility and the Space of Community". 27(3). 2003. 298-316

Reznick, Leibel. The Holy Temple Revisited. London: Jason Aronson Inc., 1990. 
Ricoeur, Paul. Time and Narrative: Volume 2. Trans. Kathleen Mclaughlin and David Pellauer. Chicago: University of Chicago, 1985.

Ricoeur, Paul. Time and Narrative, Volume 3. Trans. Kathleen Blamey and David Pellauer. Chicago: University of Chicago, 1988.

Ricoeur, Paul. "Word, Polysemy, Metaphor: Creativity in Language." A Ricoeur Reader: Reflection and Imagination. Ed. Mario J. Valdes. Toronto and Buffalo: University of Toronto Press, 1991. $65-85$.

Rieff, David. The New York Times Magazine: Arafat in His Labyrinth.

"Arafat Among the Ruins". 52-58 April 25, 2004.

Rossi, Aldo. The Architecture of the City. New York: MIT Press, 1984.

Sacco, Joe. Palestine. Seattle: Fantagraphics Books, 2001.

Sachar, Howard M. A History of Israel: From the Rise of Zionism to our Time. New York: Alfred A. Knopf, 1979.

Said, Edward. Culture and Imperialism. New York: Vintage Books, 1994.

Said, Edward. Orientalism. New York: Vintage Books, 1979.

Said, Edward. Power, Politics, and Culture. New York: Vintage Books, 2002.

Schweid, Y. The Unification of Jerusalem: The Planning Aspect. Israel:

Trans. Kivunim no. 35 (1987)

Silberman, Neil Asher. "If I Forget Thee, O Jerusalem: Archaeology, Religious Commemoration and Nationalism In a Disputed City, 1801-2001." Nations and Nationalism 7(4), 2001, ASEN 2001. 487-504.

Simons J. Jerusalem in the Old Testament. The Netherlands: E. J. Brill, Leiden, 1952.

Snohetta Architecture. Project Description: Bibliotheca Alexandrina. [online]. Available from http://www.snoarc.no/ (Accessed November 5, 2004)

Stepan, Alfred. And Graeme B. Robertson. An Arab More than Muslim Electoral Gap. Journal of Democracy. 14:3, 2003. 29-44

Sylvestre, Guy. Guidelines for National Libraries. Paris: UNESCO, 1987.

Tafuri, Manfedo. The Sphere and the Labyrinth. Trans. Robert Connolly and Pellegrino d'Acierno. Cambridge/London: The MIT Press, 1987. 1-21. 
Thompson, Anthony. National Library Buildings. Germany: IFLA Publications, 1975.

Thompson, Godfrey. Planning and Design of Library Buildings.

London: Butterworth, 1989.

Thompson, John B. Critical Hermeneutics: A Study in the Thought of Paul Ricoeur and Jurgen Habermas. Cambridge, New York: Cambridge University Press, 1981.

UNESCO. "UNESCO Bibliotheca Alexandrina website". [online].

Available from http://www.unesco.org/ (Accessed November 8, 2004).

Vukonic, B. Tourism and Religion. London: Elsevier Science, 1996.

Walker, R.B.J. "Polis, Cosmopolis, Politics" Alternatives 28(2). 2003. 267-296.

Weizman, Eyal. \& Rafi Segal. A Civilian Occupation "The Politics of Israeli Architecture". Israel: Babel, 2003.

Whiston, William. The Life and Works of Flavius Josephus. New York: Holt, Rinehart and Winston, 1936.

Wilkinson, John. Jerusalem as Jesus Knew it: Archaeology as Evidence. London: Thames And Hudson Ltd, 1978.

Yadin, Yigael. Jerusalem Revealed: Archaeology in the Holy City 1968-1974. New Haven and London: Yale University Press and the Israel Exploration Society, 1976.

Zacks, Stephen. Metropolis "Lay of the Land". New York: Bellerophon Publications, February 2003. Pg $83-126$

Zwelling J. The Fictions of Biblical History. History and Theory, February 2000, Vol. 39, No. 1, Pg. 117-141(25) Blackwell Publishing 